Maurer School of Law: Indiana University

Digital Repository @ Maurer Law

\title{
Trail Smelter Déjà Vu: Extraterritoriality, International Environmental Law and the Search for Solutions to Canadian-U.S. Transboundary Water Pollution Disputes
}

Austen L. Parrish

Indiana University Maurer School of Law, austparr@indiana.edu

Follow this and additional works at: https://www.repository.law.indiana.edu/facpub

Part of the Environmental Law Commons, and the Transnational Law Commons

\section{Recommended Citation}

Parrish, Austen L., "Trail Smelter Déjà Vu: Extraterritoriality, International Environmental Law and the Search for Solutions to Canadian-U.S. Transboundary Water Pollution Disputes" (2005). Articles by Maurer Faculty. 891.

https://www.repository.law.indiana.edu/facpub/891

This Article is brought to you for free and open access by the Faculty Scholarship at Digital Repository @ Maurer Law. It has been accepted for inclusion in Articles by Maurer Faculty by an authorized administrator of Digital Repository @ Maurer Law. For more information, please contact rvaughan@indiana.edu. 


\title{
ARTICLES
}

\section{TRAIL SMELTER DÉJÀ VU: EXTRATERRITORIALITY, INTERNATIONAL ENVIRONMENTAL LAW, AND THE SEARCH FOR SOLUTIONS TO CANADIAN-U.S. TRANSBOUNDARY WATER POLLUTION DISPUTES}

\author{
Austen L. PARrish*
}

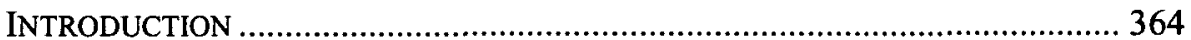

I. The Problem Of TRanSBoundary Water Pollution.................... 369

A. The Trail Smelter: A Current Crisis in U.S.-Canada

Relations ........................................................................... 369

1. The Trail Smelter's Pollution of Lake Roosevelt and the Upper Columbia River Basin ............................................... 370

2. Teck Cominco's Response and the EPA's and Colville Tribes' Search for Solutions ................................................ 376

B. The Continuing and Increasing Significance of U.S.-Canada Transboundary Pollution ............................................................. 380

II. THE LIMITATIONS OF DOMESTIC LAW ........................................ 385

A. The Demise of Territorialism and Judicial Self-Restraint: The Application of U.S. Laws to Canadian Companies

1. Obtaining Personal Jurisdiction Over Canadian Companies Under the Effects Test

2. The Extraterritorial Application of U.S. Environmental

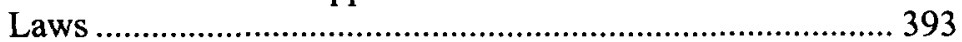

3. Canadian Judicial Enforcement of U.S. Judgments................ 399

B. The Practical and Conceptual Drawbacks to Solving Transboundary Pollution Disputes with National Adjudication ....

1. The Violation of Canadian Sovereignty and the Problems of Regulation Without Representation

\footnotetext{
* Associate Professor of Law, Southwestern University School of Law. J.D., Columbia University, 1997; B.A., University of Washington, 1994. Professor Parrish is the current Director of Southwestern's Summer Law Program in Vancouver, B.C., Canada, where he teaches International Environmental Law at the University of British Columbia. The author is grateful to Anahid Gharakhanian, Ondraus Jenkins, Tara I. Walters, and Dennis T. Yokoyama for their thoughtful comments on earlier drafts. The author is also grateful to Joost Blom, Paul S. Horwitz, and Robert E. Lutz for their advice and suggestions. Lastly, the author thanks Paul Chancellor for his research assistance.
} 
2. The Problem of Reciprocal Risk ..........................................409

3. Canada's Likely Response ................................................. 411

III. MISSED OPPORTUNITIES: THE UNDERUSE OF INTERNATIONAL

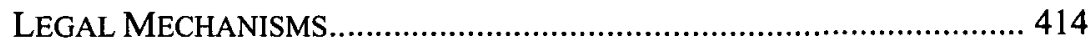

A. The 1909 Boundary Waters Treaty .......................................... 415

B. The Trail Smelter Arbitration Revisited: A Model for Adjudication

C. Responding to Critics and the Advantages to International Arbitration for Transboundary Dispute Resolution

CONCLUSION

\section{INTRODUCTION}

History repeats itself. Over seventy years ago, a privately owned smelting plant located in Trail, British Columbia - approximately seven miles from the international border - became the focus of a famous transboundary pollution dispute between the United States and Canada. ${ }^{1}$ The resolution of the dispute, known as the Trail Smelter Arbitration, became a landmark decision in international environmental law. ${ }^{2}$ In that case, a specially appointed arbitral

1 Trail Smelter Arbitration (U.S. v. Can.), 3 R.I.A.A. 1905 (1938) [hereinafter Trail Smelter I] (requiring the Canadian company operating the Trail smelter to cease causing further damage to the State of Washington), further proceedings 3 R.I.A.A. 1938 (1941) [hereinafter Trail Smelter II] (holding Canada responsible for the Trail smelter pollution and requiring Canada to conform to its treaty obligations). See generally John E. Read, The Trail Smelter Dispute, 1 CAN. Y.B. INT'L L. 213 (1963) (describing the Trail Smelter arbitration).

2 David Hunter et al., InTERnational EnVIRonmental Law and Policy 511 (2d ed. 2002); see also TUOMAS KUOKKANEN, INTERNATIONAL LAW AND THE ENVIRONMENT: VARIATIONS ON A THEME 89 (2002) (stating that "[t]he Trail Smelter case is one of the landmarks of the traditional period to which scholars constantly refer"); JAN SCHNEIDER, WORLD PUBLIC ORDER OF THE ENVIRONMENT: TOWARDS AN INTERNATIONAL ECOLOGICAL LAW AND ORganization 50 (1979) (describing the Trail Smelter arbitration as a "milestone" in the development of international environmental law); Linda A. Malone, The Chernobyl Accident: A Case Study in International Law Regulating State Responsibility for Transboundary Nuclear Pollution, 12 COLUM. J. ENVTL. L. 203, 208 (1987) (observing that "[a]ny analysis of [foreign] liability necessarily begins with the landmark Trail Smelter case"); Thomas W. Merrill, Golden Rules for Transboundary Pollution, 46 DUKE L.J. 931, 947 (1997) (remarking that "[by] far the most influential decision on transboundary pollution in international law is the Trail Smelter arbitration"); Karin Mickelson, Rereading Trail Smelter, 31 CAN. Y.B. INT'L L. 219, 219-20 (1993) (observing that the Trail Smelter Arbitration, although often "more an object of reverence than a subject of analysis" is "one of the best known and most frequently cited international decisions" that "is regarded by many scholars as the fountainhead of modern international environmental law"). But cf. Shashank Upadhye, The International Watercourse: An Exploitable Resource for the Developing Nation Under International Law?, 8 CARDOzO J. INT'L \& COMP. L. 61, 86 (2000) (describing the Trail Smelter arbitration as the "allegedly landmark international environmental decision" but finding that the decision "creates no unequivocal customary international law"). 
panel held Canada liable for property damage in the United States caused by the Trail smelter's release of sulfur dioxide from its tall smoke-stacks. ${ }^{3}$ The Trail Smelter Arbitration remains the "only decision of an international court or tribunal that deals specifically, and on the merits, with transfrontier pollution." 4 But the subject of "the most famous international environmental law dispute" has not gone away. ${ }^{5}$ Recently, the Trail smelter - one of the largest lead and zinc smelters in the world ${ }^{6}$ - has once again become the center of a heated cross-border showdown between Canada and the United States. As one commentator colorfully describes it: "Not since the Pig War of 1859 between the United States and Great Britain has there been such an international brouhaha in the Pacific Northwest."7

The latest Trail smelter dispute has been long in the making. The current row concerns tens of millions of tons of industrial waste and heavy metals that the Trail smelter dumped into the Columbia River from the 1900s through the mid-1990s. ${ }^{8}$ The Columbia River flows from British Columbia through Washington State. Deposits along the river's banks are Trail's legacy of

3 Trail Smelter II, supra note 1, 3 R.I.A.A. at 1946-47 (finding that from the years 19391940 , between 360 and 416 tons of sulfur per day were oxidized to sulfur dioxide at the plant).

${ }^{4}$ Edith Brown Weiss et al., InTERnational LaW AND Policy 257 (1998); see also Merrill, supra note 2, at 947 ("[T]he Trail Smelter Arbitration has assumed immense importance in the development of the customary international law on transboundary pollution, primarily because it is the only adjudicative decision of an international tribunal that speaks directly to the substantive law of transboundary pollution.").

5 HUNTER ET AL., supra note 2, at 511.

${ }^{6}$ Amy Crook, Envtl. Mining Council of B.C., Briefing Papers: Trail Smelter (2003), http://www.miningwatch.org/emcbc/Publications/briefing_papers/trail.htm (last accessed Feb. 9, 2005) (explaining that Teck Cominco's Trail operation is "the world's largest fully-integrated zinc and lead smelting and refining complex with production capacities of approximately 300,000 tonnes/year of zinc and 120,000 tonnes/year of lead" and a "significant producer of silver, gold, indium, germanium, bismuth, and copper products, including copper sulphate and copper arsenate.").

${ }^{7}$ EPA battles Canadian company over Columbia River, U.S. WATER NEWS ONLINE, Dec. 2003, at http://www.uswaternews.com/archives/arcquality/3epabat12.html (last accessed Feb. 9, 2005).

${ }^{8}$ Canadian Polluter Should Fund Study, SpOKESMAN-Rev. (Spokane), Oct. 13, 2003, at A14 (stating that the Trail smelter "dumped 98 million tons of heavy metals into the Columbia River"); Joel Connelly, Canadian Smelter Pollution Meets U.S. Resolution, Seattle Post-Intelligencer, Nov. 12, 2003, at A2 (stating that the Trail smelter in six decades "dumped nearly 10 million tons of black slag in the [Columbia] river"); Papers Show Toxic Dumping into Columbia, Seattle Post-InTElligencer, June 21, 2004, at B2, available at 2004 WL 60142957 (citing a 1981 memorandum from the British Columbia environment ministry that said the Trail smelter had deposited about twenty pounds of mercury a day into the Columbia over many years); Matt Preusch, Pollution Dispute in the Northwest Straddles the Border, N.Y. TIMES, March 20, 2004, at 8 (discussing Trail smelter's dumping of twenty million tons of industrial waste). 
industrial contamination in the form of slag: a fine, black, sand-like byproduct of the smelting process. One reporter explains that the Trail smelter dumped the equivalent of "a dump truck of slag" into the Columbia River every hour for sixty years. ${ }^{9}$ As a result of the dumping, in the early 1990s the Trail smelter discharged more toxic waste into the Columbia River than all other polluters combined discharged into all other Washington State rivers. ${ }^{10}$

That environmental impacts would result from these toxic waste discharges is hardly surprising. U.S. citizens living along the river near the Canadian border, including Native American tribes, claim that the discharges have caused major environmental and human-health problems, damaged their lands, and threatened their traditional ways of life. ${ }^{11}$ Because of the pollution, citizens around the Columbia River-Lake Roosevelt area are "afraid of swimming in the lake, of eating the fish and even of walking on the beaches."12 After finding exceptionally high quantities of arsenic, lead, mercury and other contaminants in the river known to cause illness and kill aquatic life, the U.S. Environmental Protection Agency (EPA) is considering the site for listing and cleanup under the Superfund (CERCLA) ${ }^{13}$ laws. ${ }^{14}$

Although the environmental problems that the toxic waste discharges caused may have been predictable, the EPA's response was not. The EPA has demanded that the Trail smelter submit to its jurisdiction to clean up the

${ }^{9}$ Chris Brown, A Century of Slag, CBC NEws, Dec. 15, 2003, at http://www.cbc.ca/news/background/environment/centuryofs̉lag.html (last accessed Feb. 9, 2005).

${ }^{10}$ Nicholas K. Geranios, Report on Major Polluters Ignores Teck Cominco Smelter, AsSOC. PRESS NEWSWIRES, July 1, 2004 (discussing analysis by Washington Public Interest Research Group of pollutants released into Washington state waters); see also HUNTER ET AL., supra note 2, at 511 (observing that the Trail smelter continues to cause "major environmental problems both within British Columbia and across the border in Washington State" and in the 1990 s "was listed on the province's list of 85 worst polluters"); Karen Dorn Steele, British Columbia Smelter Dumped Tons of Mercury into River, Documents Reveal, SPOKESMAN-REV. (Spokane), June 20, 2004, available at 2004 WL 62369852 (discussing a report that shows that the Trail smelter's 1994 and 1995 discharges of cooper and zinc exceeded the cumulative totals for U.S. companies, and that mercury discharges were equivalent to $40 \%, 20 \%$ and $57 \%$ of all U.S. releases in 1995,1996 and 1997 respectively).

11 See, e.g., Complaint at $\$ 4.6-4.7$, Pakootas v. Teck Cominco Metals, Ltd., No. CV04-0256-AAM (E.D. Wash. filed June 21, 2004) (claiming that specially reserved tribal hunting and fishing rights have been impaired by the discharge of hazardous slag).

${ }^{12}$ Lindsey Rowe, Colville Tribes File Lawsuit Over Sludge in Lake Roosevelt, SEATTLE POST-INTELLIGENCER, July 22, 2004, at B1 (reporting that the beaches show "evidence of the sludge in "black sand"').

${ }^{13}$ Comprehensive Environmental Response, Compensation, and Liability Act (CERCLA), 42 U.S.C. $\S \S 9601-9675$ (2000).

14 EPA, EPA to Investigate Upper Columbia River Pollution, EPA ENVIRONMENTAL FACT SHEET, June 2004, at 2 (discussing how federal and state studies demonstrate "elevated levels of contamination in Upper Columbia River sediments"). 
Columbia-Lake Roosevelt area, and has attempted to apply the Superfund laws extraterritorially. ${ }^{15}$ This attempt to subject a Canadian company, which operates solely in Canada, to EPA jurisdiction is highly controversial. Equally controversial and unprecedented is the recent federal lawsuit filed by two members of the Colville Confederated Tribes, an aboriginal tribe in Washington State. ${ }^{16}$ That lawsuit is believed to be the first case ever of Americans suing a Canadian company under the citizen's suit provisions of the U.S. Superfund laws. ${ }^{17}$ Although the Trail smelter has volunteered to take certain clean-up measures, including offering $\$ 13$ million for studies and remediation, it refuses to bend to either the EPA's or the Colville Tribes' demands. ${ }^{18}$

The reemergence of the Trail smelter dispute raises significant questions about the ability of Canada and the United States to resolve transboundary pollution disagreements:

- Should U.S. domestic environmental laws be applied and enforced extraterritorially against Canadian companies that operate exclusively in Canada?

- What international legal mechanisms exist to resolve transboundary water pollution disputes between the United States and Canada satisfactorily and effectively?

- What lessons may be drawn from the original Trail Smelter Arbitration decided over sixty years ago?

Answers to these questions are important, for the Trail smelter dispute does not stand alone. The United States has numerous other environmental disputes along the Canadian border that are either ongoing or are in the making, and the

${ }^{15}$ Special Notice Letter from David Croxton, EPA Unit Manager, Office of Environmental Cleanup, to Teck Cominco Metals, Ltd. (Oct. 10, 2003) (on file with author) (addressing cleanup of the Upper Columbia River site); see also News Release, Teck Cominco, EPA Takes Unprecedented Step to Impose U.S. law in Canada 1 (Dec. 11, 2003), available at http://www.teckcominco.com/news/03-archive/03-24-tc.htm (last accessed Feb. 10, 2004).

${ }^{16}$ Christopher Schwarzen, 2 Colvilles File Suit Against B.C. Firm, SEATTLE TIMES, July 22,2004 , at B5; see also Rowe, supra note 12, at B1. Throughout this article the Colville Confederated Tribes will be referred to as the "Colville Tribes." Although the lawsuit, for purposes of CERCLA, was brought by two individual members of the Tribe, the Article does not distinguish between the two individual members and the Colville Tribes themselves.

17 Washington State Tribe Sues Canada Smelter Over Pollution, Dow JONES INT'L NewS, July 22, 2004 (stating that the case is believed to be "the first case of Americans suing a Canadian company under U.S. Superfund law").

18 Schwarzen, supra note 16, at B5; see also Letter from David Thompson, Deputy Chairman and CEO of Teck Cominco Ltd., to the U.S. EPA (Nov. 14, 2003), at http://www.teckcominco.com/articles/roosevelt/dt-letter-031114.htm (last accessed Feb. 10, 2004). 
number of disputes is expected to grow. ${ }^{19}$ Accordingly, the countries need an effective means to resolve their transboundary pollution problems.

This Article discusses some of the legal mechanisms available to resolve transboundary water pollution disputes between the United States and Canada, as viewed through the context of the current Trail smelter dispute. This Article concludes that the use of international arbitration provides an effective, and too often overlooked, way to resolve transboundary water pollution issues. Part I describes the current Trail smelter dispute, and the unique environmental problems the Trail smelter is believed to have caused to the Upper Columbia River Basin. Part II analyzes the legal obstacles facing the U.S. Environmental Protection Agency and others wishing to use domestic environmental laws to hold Canadian companies liable for transboundary pollution. Although the United States may be successful in its attempt hold Canadian polluters liable through EPA initiated U.S. domestic litigation, extraterritorial application of U.S. environmental law creates significant problems, and seriously encroaches upon Canadian sovereignty. Ultimately, the national adjudication of crossborder disputes does not provide a long-term solution to transboundary pollution. Part III explores an available, underutilized international environmental law mechanism that the countries could potentially use to effectively resolve the Trail smelter and similar disputes. In particular, it focuses on the 1909 Boundary Waters Treaty and the famous Trail Smelter Arbitration. To the extent that Canada and the United States attempt to resolve disputes legally, rather than through diplomatic negotiation, ${ }^{20}$ the best legal solution to those disputes may lie in international arbitration. International arbitration, modeled after the famous Trail Smelter Arbitration, provides both a more diplomatically and conceptually satisfying means of solving transboundary water pollution disputes than national adjudication. Indeed, despite its contentiousness, the current Trail smelter dispute provides a unique opportunity to set the stage for renewed environmental cooperation between the United States and its northern neighbor.

19 See infra Section II.B (discussing the difficulties of applying national adjudicatory remedies to transboundary pollution disputes).

${ }^{20}$ Catherine A. Cooper, The Management of International Environmental Disputes in the Context of Canada-United States Relations: A Survey and Evaluation of Techniques and Mechanisms, 24 CAN. Y.B. INT'L L. 247, 255-308 (1986) (discussing the resolution of crossborder environmental disputes between Canada and the United States); John N. Hanson et al., The Application of the United States Hazardous Waste Cleanup Law in the Canada-U.S. Context, 18 CAN.-U.S. L.J. 137, 137-38 (1992) (observing that the U.S. and Canada traditionally used diplomacy to settle transborder environmental issues). As Marcel Cadieux, former Ambassador of Canada to the United States once explained, there is a preference "on the part of both Canada and the United States "to resolve their disputes through negotiation rather than through adopting a strictly legal approach."' Erik B. Wang, Adjudication of Canada-United States Disputes, 19 CAN. Y.B. INT'L L. 158, 159 (1981) (quoting Marcel Cadieux, Sixth Annual Conference of the Canadian Council on International Law, Ottawa, October 21, 1977, 1 CAN.-U.S. L.J. 19 (1978)). 


\section{THE PROBLEM Of TRANSBOUNDARY Water POLLUTION}

Legal scholars have long studied transboundary pollution, particularly transboundary water pollution. ${ }^{21}$ The recent dispute over the Trail smelter's pollution of the Columbia River, however, is unique in the context of U.S.Canadian relations because of its contentiousness. For this reason, it provides a useful lens through which to re-examine transboundary water pollution issues affecting the United States and Canada. Finding a mechanism to solve U.S.Canada cross-border disputes that cannot be resolved diplomatically is more important than ever, precisely because of the increasing number of U.S.Canadian transboundary water disputes that are not readily solved through diplomatic channels. ${ }^{22}$

\section{A. The Trail Smelter: A Current Crisis in U.S.-Canada Relations}

Teck Cominco Metals, Ltd. owns and operates one of the world's largest zinc and lead refining and smelting complexes in Trail, British Columbia, Canada. ${ }^{23}$ The smelter has been operating in Trail since $1896 .{ }^{24}$ Although the Trail smelter was "originally built to process materials from local mines," it now processes ore concentrates from mining operations throughout the world. ${ }^{25}$ The facility produces "lead, zinc, cadmium, silver, gold, bismuth, antimony, indium, germanium, and arsenic, as well as sulfuric acid and liquid sulfur dioxide." 26

Given the Trail smelter's location, transboundary disputes are not surprising. The smelter is on the Columbia River, approximately seven miles from the

21 The literature discussing the pollution of international watercourses is voluminous. See, e.g., Patricia Bernie \& Alan Boyle, International LaW \& The ENVIRONMENT 298331 (2d ed. 2002); HUNTER ET AL., supra note 2, at 769-809; ALEXANDRE KISS \& DINAH SHELTON, INTERNATIONAL ENVIRONMENTAL LAW 453-493 (3d ed. 2004); ANDRÉ Nollkaemper, The Legal Regime for Transboundary Water Pollution: BetweEN DISCRETION AND CONSTRAINT 13-14 (1992) (summarizing several comprehensive studies on transboundary water pollution); WEISS ET AL., supra note 4, at 577-640; Peter-Tobias Stoll, Transboundary Pollution, in INTERNATIONAL, REGIONAL AND NATIONAL ENVIRONMENTAL LAW 169-200 (Fred L. Morrison \& Rüdiger Wolfrum eds., 2000).

${ }^{22}$ For a discussion of the benefits of resolving disputes by legal/arbitral proceedings rather than diplomacy, see L.H. Legault, The Roles of Law and Diplomacy in Dispute Resolution: The IJC as a Possible Model, 26 CAN.-U.S. L.J. 47, 48-49 (2000).

${ }^{23}$ CROOK, supra note 6; see also TECK COMINCO, TRAIL SMELTER AND REFINERIES, B.C., CANADA (April 2, 2004), at http://www.teckcominco.com/operations/trail/index.htm.

24 In 1896, the smelter was started by Americans. In 1906 the Consolidated Mining and Smelting Company of Canada, Ltd., acquired the smelter. That company was renamed Cominco in 1966, and merged with Teck, Ltd. to become Teck Comino Metals, Ltd. in 2001. CROOK, supra note 6; see also Trail Smelter II, supra note 1, 3 R.I.A.A. at 1944-48.

25 U.S. EPA, UPPER COLUMBIA RIVER EXPANDED SITE INSPECTION REPORT NORTHEAST WASHINGTON at 2-11 (2003) [hereinafter EPA COLUMBIA RIVER REPORT].

${ }^{26}$ Id. 
United States-Canada border, north of Lake Roosevelt, in Washington State. ${ }^{27}$ The area just south of the international boundary - known as the Upper Columbia River Basin - is mostly inhabited by Native American tribes and local farmers. ${ }^{28}$ Ancestral homes of both the Colville Tribes and the Spokane Tribe exist in the area. ${ }^{29}$ The Upper Columbia River is "home to the endangered peregrine falcon and the threatened bald eagle, bull trout and white sturgeon." 30 The area is also a significant tourist destination. The Lake Roosevelt National Recreation Area attracts more than a million visitors each year. ${ }^{31}$

\section{The Trail Smelter's Pollution of Lake Roosevelt and the Upper Columbia River Basin}

The current dispute involves the Trail smelter's discharge of slag into the Columbia River. Slag, a byproduct of the smelting process, is "a black, glassy material which contains copper, lead, and zinc" as well as other heavy metals. $^{32}$ From the early $1900 \mathrm{~s}$, in the beginning days of the smelter's operation, until 1995 when the smelter discontinued routine slag discharges, ${ }^{33}$ the Trail smelter dumped between 145,000 and 186,000 metric tons of slag annually into the Columbia River. ${ }^{34}$ In total, the EPA estimated that the Trail

${ }^{27}$ Id.; see generally WEISS ET AL., supra note 4, at 245-46 (explaining that the smelter is "just north of the international boundary, about seven miles as the crow flies, or about eleven miles along the course of the [Columbia] river").

${ }^{28}$ EPA COLUMBIA RIVER REPORT, supra note 25, at 2-3; see also Trail Smelter II, supra note 1, 3 R.I.A.A. at 1941-45.

${ }^{29}$ EPA COLUMBIA RIVER REPORT, supra note 25, at 2-3.

${ }^{30}$ Letter from Robert Pregulman, Executive Director, The Washington Public Interest Research Group (WashPIRG), to WashPIRG Supporters and the EPA 2 (June 18, 2003) (on file with author) (regarding the clean-up of Lake Roosevelt).

${ }^{31}$ Id ; see also National Park Service, U.S. DeP'T OF THE INTERIOR, LAKE RoOSEVelT NATIONAL RECREATION AREA: FACTS (stating that total "recreation visits" to the area in 2003 equaled 1,363,483), at http://www.nps.gov/laro/pphtml/facts.html (last accessed Feb. $1,2005)$.

32 EPA COLUMBIA RIVER REPORT, supra note 25, at 2-11.

${ }^{33} I d$. at 2-13 ("According to a summary report prepared by consultants to Cominco, the routine discharge of slag into the Columbia River was discontinued in mid-1995."); see also WEISS ET AL., supra note 4, at 263 (discussing how Teck Cominco "was pressured by British Columbia's provincial government, as well as by downstream residents and agencies in Washington, to reduce the pollutants that had been poured into the river for decades); Cominco Advances Date for Switch to Land-Based Slag Disposal System, CAN. NEWSWIRE, Aug. 14, 1992 (discussing Teck Cominco's plan to move to a land-based slag disposal system by mid-1995, eighteen months ahead of the original schedule).

${ }^{34}$ EPA COLUMBIA RIVER REPORT, supra note 25, at 2-11; see also MICHAEL S. MAJEWSKI ET AL., U.S. DEP'T OF THE INTERIOR, CONCENTRATIONS AND DISTRIBUTION OF SLAG-RELATED Trace Elements and Mercury in Fine-Grained Beach and Bed Sedments of LaKe ROOSEVELT, WASHINGTON, APRIL-MAY 20012 (2001) (explaining that the "[Trail] smelter 
smelter discharged approximately twelve million tons of slag into the Columbia River over the course of operations from 1940 through $1994 .^{35}$ The director of pollution control for the B.C. Ministry's waste management branch described the situation well: "Since the turn of the Century, the Columbia River has been used by the company as a repository for a vast array of its highly contaminated wastes, sludges and accidental spills." 36

The amount of heavy metals and other contaminants that the Trail smelter dumped into the Columbia River is remarkable. In a 2003 report, the EPA concluded that the smelter discharged unacceptably high concentrations of arsenic, cadmium, and mercury throughout the 1980s and 1990s. ${ }^{37}$ One recent study, prepared this year for the Colville Tribes, reports that in 1994 and 1995 copper and zinc discharges from the Trail smelter exceeded the cumulative total for all U.S. companies. ${ }^{38}$ In addition to slag, the Trail smelter dumped or spilled, at various times, large quantities of mercury and sulfuric and phosphoric acids. ${ }^{39}$ According to Canadian government documents, the Trail smelter has discharged between 1.6 and 3.6 tons of mercury into the river each year since the $1940 \mathrm{~s}^{40}$ The yearly mercury discharges were the equivalent of

discharged slag directly into the Columbia River at a rate of about 397 tons per day from 1930 until the early 1990s").

35 EPA COLUMBIA RIVER REPORT, supra note 25, at 2-11.

36 Steele, supra note 10 (quoting R.H. Ferguson, Director of Pollution Control for B.C. Ministry's waste management branch); see generally, Toxic-Trail, BROAD. NEws (Canada), Aug. 22, 2001, available at 2001 WL 26722134 (observing that the Lonely Planet travel magazine called Trail "the most toxic place in Canada" and quoting others about the pollution in Trail).

${ }^{37}$ EPA COLUMBIA RIVER REPORT, supra note 25, at 2-11 ("A trend graph of metals in effluents from the metallurgical operation from 1980 to 1996 demonstrates that the average discharges for dissolved metals were as high as 18 kilograms per day $(\mathrm{kg} / \mathrm{d})$ of arsenic, 62 $\mathrm{kg} / \mathrm{d}$ of cadmium, $200 \mathrm{~kg} / \mathrm{d}$ of lead, and $7,400 \mathrm{~kg} / \mathrm{d}$ of zinc. . . fertilizer plant operations contributed up to $4 \mathrm{~kg} / \mathrm{d}$ of total mercury and $350 \mathrm{~kg} / \mathrm{d}$ of dissolved zinc.") (citing TECK COMinico, Trail Operations, 1996 anNual ENVIRONMENTAL RePOrt (1997)).

38 Steele, supra note 10.

39 EPA COLUMBIA RIVER REPORT, supra note 25, at 2-13; see also Canadian Polluter Should Fund Study, SPOKESMAN-REv. (Spokane), Oct. 13, 2003, at A14, available at 2003 WL 57391705; Connelly, supra note 8, at A2 (reporting that in 1992 the British Columbia government "gave the smelter a permit to pour up to 200 tons of sulphuric acid a day into the Columbia river" and the same year spilled 187 pounds of mercury and 855 tons of sulfur dioxide into the river); Memorandum from the B.C. Ministry of Environment, Waste Management Branch (Oct. 26, 1981) (on file with author) (listing spills that occurred at Cominco Trail in 1979-1981 and showing, among other spills, that over 140 tons of sulfuric acid spilled into the Columbia River in September and October 1981).

40 Papers Show Toxic Dumping Into Columbia, supra note 8, at B2; see also Letter from A.E. Park, Deputy Director, U.S. Transboundary Relations Division, Canadian Department of External Affairs, to B.E. Marr, Deputy Minister of the Environment (July 29, 1980) (on file with author) (enclosing a copy of a Note from the U.S. State Department on the subject of a mercury spill into the Columbia River by Cominco Ltd., and the Canadian Reply); 
$40 \%, 20 \%$, and $57 \%$ of all U.S. releases of mercury into water in 1995,1996 , and 1997 , respectively. ${ }^{41}$

The Trail smelter's discharges have caused environmental harm. Many consider the Upper Columbia River Basin toxic: a series of studies document elevated concentrations of trace elements - above acceptable Canadian and U.S. standards - such as "arsenic, cadmium, copper, lead, mercury and zinc in the water, bed sediment, and fish of Lake Roosevelt and the upstream reach of the Columbia River." 42 In 1989, tests confirmed "that suspended particles of lead in the air were a serious health concern for people in Trail - not just for workers, but also for children."43 Studies that the Canadian Department of Fisheries and the Washington State Department of Health conducted in the early 1990 s concluded that the Trail smelter slag releases were toxic to various aquatic species. ${ }^{44}$ One 1994 study "revealed some of the highest levels of

Steele, supra note 10 (describing a 1981 memorandum from British Columbia's Ministry of the Environment indicating that approximately twenty pounds of mercury a day were deposited into the Columbia River).

41 Steele, supra note 10.

42 Majewski et AL., supra note 34, at 1; see also STEPHEN E. Cox ET AL., U.S. GEOLOGICAL SURVEY INVESTIGATIONS REPORT: VERTICAL DISTRIBUTION OF TRACE-ELEMENT Concentrations and Occurrence of Metallurgical Slag Particles In ACCumulate Bed Sediments of LaKe Roosevelt, Washington, SePtember 2002 5-6 (U.S. Geological Survey 2005) (listing various studies from the 1970s through the 1990s. "that attributed the source of elevated trace elements [including arsenic, cadmium, copper, lead, mercury and zinc] to the discharge smelter wastes" from Trail, including studies and reports from the British Columbia Ministry of Environment, Environment Canada, private consulting firms, and the U.S. Geological Survey); G.C. BORTLESON ET AL., SEDIMENT-QUALITY ASSESSMENT

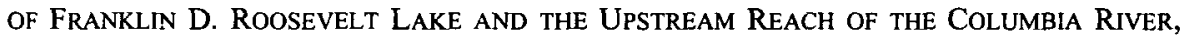
WASHINGTON 130 (U.S. Geological Survey 1992) (reporting that Lake Roosevelt beach and bed sediments contained elevated concentrations of trace elements-arsenic, cadmium, copper, lead, mercury, and zinc-and that the concentrations of these elements were highest at sites closest to the smelter source); BRANDEE ERA \& DAVE SERDAR, REASSESSMENT OF ToXicity of LAKE RoOSEVElt Sediments 23 (Wash. Dep't of Ecology 2001) ("Metal concentrations and toxicity levels in the upper Columbia River and Lake Roosevelt sediments remain relatively high."). See generally LAKE ROOSEVELT FORUM, SEDIMENT CONTAMINATION AND LAKE ROOSEVELT (2004), at http://www.lrf.org/Env/EvnSediment.html (noting that since 1986 the United States Geologic Survey, the Washington Department of Ecology and the EPA have conducted studies, which have found that Lake Roosevelt has nigh levels of toxic contaminants).

${ }^{43}$ Brown, supra note 9 (detailing early EPA studies); see also HUNTER ET AL., supra note 2, at 511 (observing that the Trail smelter continues to cause "major environmental problems both within British Columbia and across the border in Washington State" and emitted lead beyond the legal levels "and was listed on the province's list of 85 worst polluters") (citing L. Pynn, Polluters' List Grows Faster than Prosecutions, VANCOUVER Sun, March 3, 1995).

44 J.C. NENER, B.C. DEP'T OF FISHERIES AND OCEANS, SURVIVAL AND WATER QUALITY of BioAsSays on Five Species of AQUatic ORganisms Exposed to Slag from Cominco's 
cadmium and arsenic ever recorded, as well as high levels of airborne lead."45 Another inspection showed zinc levels near the Canadian border to be sixty times what is considered safe for aquatic life and fish..$^{46}$

Based on these studies, and on the visible slag in the river, local residents believe a range of illnesses that have ravaged the area are attributable to the water pollution - illnesses including cancer, colitis, and leukemia. ${ }^{47}$ The Washington State Health Department supports this observation, finding in the mid-1990s that "hospital rates in Northport [a town located ten miles downwind of Trail] for bowel diseases, e.g., ulcerative colitis and Crohn's disease, were higher than the state average." 48 In 1994, the Washington State Department of Health began advising the public to limit consumption of certain kinds of salmon because of mercury contamination. ${ }^{49}$

Trail Operations (1992); Glen Patrick, Wash. St. Dep't of Health, Cominco Slag in LAKe RoOSEVElT: REVIEW OF CURRENT DATA (1993); see also MARTHA L. ERVWIN \& MARK D. MunN, ARE Walleye From LaKe RoOSEvelt ConTAMINATED WITH MERCuRY (August 1997) (discussing the high concentrations of mercury in Walleye and the concern about fish from Lake Roosevelt because "a smelter in British Columbia discharged waste and slag into the Columbia River for many years . . ..); MARK D. MUNN, U.S. GEOlOGICAL SURVEY WATER-RESOURCES INVESTIGATIONS REPORT: CONTAMINANT TRENDS IN SPORT FISH FROM LAKe RoOSEVElT AND THE UPPER COlumbia RIVER, WASHINGTON, 1994 TO 1998 1, 3-5 (2002) (noting a decrease in contaminants in fish from the 1990s attributable to industrial discharges to the Columbia river, but recognizing that fish from Lake Roosevelt continue to contain elevated concentrations of contaminants).

45 WEISS ET AL., supra note 4, at 263 (discussing how residents of the region had an unusually high incidence of gastrointestinal problems).

${ }^{46}$ Karen Dorn Steele, State, Tribes Wants EPA to Oversee Lake Cleanup: Ecology Push to Designate Roosevelt for Superfund Causing Transborder Tension, SPOKESMAN-REV. (Spokane), April 23, 2003, at B1, available at 2003 WL 6405384 (stating that "[a] recent EPA site inspection shows zinc levels near the Canadian border 60 times what's considered safe for aquatic life and fish").

${ }^{47}$ Brown, supra note 9 (interviewing (1) Bob Jackman, a retired police detective who lives in Northport, five minutes south of the border, who "wonders whether a range of illnesses, from cancer to colitis, in those living nearby can be traced to river pollution"; and (2) Paddy Stone from the Colville Tribe, who "believes his older relatives lived long lives because the Columbia was healthy back then and now that the river is sick, so is he - with leukemia"); Memorandum from Desautel Hege Communications, Transcript of News Conference on the Lake Roosevelt/Teck Cominco Issue, to Joe Pakootas et al. 2 (July 27, 2004) (on file with author) [hereinafter News Conference Transcript] (including statement of tribal member that "We have a number of Tribal and community members that are being diagnosed with cancers and various other diseases.").

48 WEISS ET AL., supra note 4, at 263 (citing to Mark Jewell, Air Pollution Clouds Border Relationship, Canadian Smelter May Cause Illness, TACOMA NEws TRIBUNE, May 10, 1994, at B4, available at 1994 WL 4629985 (quoting the Mayor and postmaster of Northport as saying that a high incidence of disease is well known among the population)).

49 Joel Connelly, B.C. Pollution is Fouling the Fish at Coulee, Senttle PostINTELLIGENCER, April 10, 1991, at A1, available at 1991 WL 4281595 (describing a state 
In addition to the environmental and human-health hazards, pollution in the Columbia River deeply impacts Native Americans, who have lived in the Columbia River Basin for hundreds of years. ${ }^{50}$ The Colville tribes greatly depend on the resources of the Upper Columbia basin, including its "fish, wildlife, plants, lands, and waters." 51 The Colville Tribes claim that the hazardous contaminants the Trail smelter discharged have harmed their "subsistence, culture, and spiritual well-being," and that those discharges have impaired the Colville Tribes' "hunting, fishing, and gathering rights." 52 In a news conference held in July 2004, a Colville Tribes' member explained the pollution's effects this way:

You hear stories from the elders of how the [Columbia] river used to be and Kettle falls being able to walk across the river on the backs of the salmon. Now you talk to the elders and their stories are that they are

health advisory that "[s]port fishermen should limit consumption of sturgeon and whitefish caught in Lake Roosevelt because of toxic chemicals dumped into the Columbia River upstream by a Canadian pulp mill"); see also LAKE ROOSEVELT FORUM, ENVIRONMENT: SEDIMENT CONTAMINATION AND LAKE RoOSEvelt (2004), at http://www.lrf.org/Env/EvnSediment.html (discussing the possible environmental and human health concerns raised by the slag contaminaticn and noting that in 1994, the Washington State Department of Health recommended against eating Walleye Salmon because of mercury contamination); Washington State Department OF Health, Fish and Shellfish Consumption ADVISORIES IN WASHINGTON STATE (2004), at http://www.doh.wa.gov/ehp/oehas/EHA_fish_adv.htm (recommending, based on mercury levels, that "pregnant women, women of childbearing age and children under six years of age eat no more than two meals per month of walleye caught from Lake Roosevelt"). Although no study has determined exactly the health effects of this contamination, the dangers of mercury in fish are now well-known. See generally Wendy Thomas, Note, Through the Looking Glass: A Reflection on Current Mercury Regulation, 29 CoLUM. J. ENVTL. LAW 145, 159-68 (2004) (explaining the dangers of mercury from fish consumption).

50 See generally COLVILLE TRIBES, OUR HISTORY (2004) (recording the heritage of the Colville Tribes), at http://www.colvilletribes.com/past.htm (last accessed Feb. 4, 2005). See also WASHINGTON STATE GOVERNOR'S OFFICE OF INDIAN AFFAIRS, CONFEDERATED TRIBES OF THE COLVILLE RESERVATION (2004) (listing the numerous tribes that have formed to create the Confederated Tribes of the Colville Reservation), at http://www.goia.wa.gov/Tribal-Information/Tribes/colville.htm (last accessed Feb. 17, 2004).

${ }^{51}$ Richard A. Du Bey \& Jennifer Sanscrainte, The Role of the Confederated Tribes of the Colville Reservation in Fighting to Protect and Clean-Up the Boundary Waters of the United States: A Case Study of the Upper Columbia River and Lake Roosevelt Environment, 12 PeNn. St. ENVT'L. L. ReV. 335, 342 (2004) (citing WORLd COMMISSION ON DAMS, CASE StUdy, USA: GRAND CoUleE DAM \& Columbia River Basin 31 (2000)); see also Antoine v. Washington, 420 U.S. 194, 196 (1975) (discussing history of Colville Tribes and their use of land for hunting and fishing).

52 See Complaint at $9.4-4.7$, Pakootas v. Teck Cominco Metals, Ltd., No. CV-040256-AAM (E.D. Wash. filed June 21, 2004) (delineating the physical effects of the slag). 
afraid to eat the fish, to swim in the river ... some of them are even afraid to walk on the beaches now.... I would hope one day ... our kids would be able to tell their kids its safe to play in the water or swim in the water, walk on the beaches and eat the fish. ${ }^{53}$

Change has not occurred quickly. Not until 1995 did the Trail smelter under pressure from the Canadian government and other groups ${ }^{54}$ discontinue its slag discharges. ${ }^{55}$ As a result of facility renovations, the pollution decreased significantly in the late 1990s, but it has not stopped..$^{56}$ In 2001, scientists from the U.S. Geological Survey and the U.S. Department of the Interior confirmed not only the continuing toxicity of the river water, but expressed a "growing concern ... over the potential threat of airborne contaminants to human health." "57 A Washington State environmental group reported that in 2002 alone the "Trail smelter dumped [sixty-five percent] more lead, more than [a hundred] times more arsenic, and three times as much mercury as all Washington industries dumped into [Washington] state waters" combined..$^{58}$

53 News Conference Transcript, supra note 47, at 8.

54 WEISS ET AL., supra note 4, at 263 (explaining that Teck Cominco "was pressured by British Columbia's provincial governments, as well as by downstream residents and agencies in Washington, to reduce the pollutants that had been poured into the river for decades"); Joel Connelly, Political Turmoil Thwarts Cleanup of B.C. Pollution, SEATTLE POST-INTELLIGENCER, April 23, 1991, at A2, available at 1991 WL 4282857 ("Spurred by Washington's congressional delegation, agencies in Washington, D.C., and Olympia have started to pressure Canadian counterparts over pollution of waters shared by Canada and the United States."); Smelter Told to Cut Pollution, Portland Oregonian, Feb. 18, 1992, at B4, available at 1992 WL 6805205 (explaining that "Washington residents and environmental regulators have pressured Canadian officials and Cominco Ltd. over pollution from its smelter in Trail").

${ }^{55}$ See supra note 33 and accompanying text (discussing pressure exerted on Teck Cominco to discontinue slag discharge by 1995).

56 EPA COLUMBIA RIVER REPORT, supra note 25, at 2-13 to 2-14 (explaining that between 1995 and 1999, the percent reduction for several key metals from all sources (air, slag, and water) discharged directly into the Columbia River was reported to be $90 \%$ for arsenic, $84 \%$ for cadmium, $99 \%$ for cooper, $77 \%$ for lead, $95 \%$ for mercury, and $92 \%$ for zinc); see also MAJEWSKI ET AL., supra note 34, at 2 (finding that the stopping of slag discharges in 1995 and the construction of a new smelter and improved effluent treatment controls "resulted in a significant decrease in the current loadings of trace elements and slag into the system" but that "large quantities of contaminated sediments remain in Lake Roosevelt").

57 MAJEWSKI ET AL., supra note 34, at 1 (stating that the U.S. Geological Survey assessment was undertaken in response to these concerns).

58 See Geranios, supra note 10 (indicating that "Teck Cominco reported releasing 4,224 pounds of lead, 1,418 pounds of arsenic and 28 pounds of mercury into the Columbia River in $2002 \ldots$ while Washington industries dumped 2,738 pounds of lead, 12 pounds of arsenic, and 9 pounds of mercury into the state's waters in total"). 


\section{Teck Cominco's Response and the EPA's and Colville Tribes' Search for Solutions}

Although a significant number of studies and reports suggest the Upper Columbia River has suffered environmental damage, experts disagree as to the cause of the damage and its extent. Teck Cominco, for its part, asserts no wrongdoing. ${ }^{59}$ Teck Cominco scientists claim that slag is not hazardous, and that the mercury levels in Lake Roosevelt are not dangerous. ${ }^{60}$ Teck Cominco has argued that the EPA is releasing misleading, or even worse, wrong information. ${ }^{61}$ The company also explains that "it has spent more than $\$ 1$ billion in plant improvements over the last 20 years" to improve its facilities and curb pollution discharges. ${ }^{62}$ Teck Cominco has voluntarily offered to spend $\$ 13$ million to study the pollution's effects, ${ }^{63}$ but will not agree to

${ }^{59}$ Numerous documents espouse Teck Cominco's position regarding the EPA's enforcement action. See TECK COMINCO, LTD., INFORMATION REgaRding TECK COMINCO AMERICAN INC.'S INTERACTION WITH the UNITED STATES ENVIRONMENTAL PROTECTION AGENCY REGARDING LAKE ROOSEVELT, at http://www.teckcominco.com/articles/roosevelt/index.htm (last accessed Feb. 17, 2004). Included are several press releases, transcripts of conferences, and general background material on the dispute.

${ }^{60}$ Conference Call from Teck Cominco Ltd., to Investors 2 (Dec. 17, 2003) (transcript available at http://www.teckcominco.com/articles/roosevelt/transcript-confcall-17dec03.pdf) (last accessed Feb. 17, 2005) (discussing Teck Cominco's discussions with the EPA and the issues involving Lake Roosevelt).

61 Id. at 2 (accusing the EPA of putting out "misleading" and "wrong" information regarding Lake Roosevelt); see also Letter from Bill A. Williams \& Richard Cardwell, Senior Environmental Consultants, Kennedy Jenks Consultants, to Dave Croxton, U.S. EPA Region 10, at 2-3 (Feb. 20, 2004) (on file with author) (arguing that the EPA has repeatedly misrepresented Teck Cominco's proposed studies), available at http://www.teckcominco.com/articles/roosevelt/croxton-040220.pdf (last accessed Feb. 17, 2005)

62 Teck Cominco, LtD., Backgrounder: Teck Cominco, the EPA, AND Lake ROOSEVELT (2004), (arguing further that "[d]ischarges from the facility are now lower than the natural metal loads carried by the river"), http://www.teckcominco.com/articles/roosevelt/background.htm (last accessed Feb. 5, 2005); see also Teck Cominco Calls Report on Mercury Spills Into River "Extremely Misleading," CAN. PrEss, June 22, 2004, available at 2004 WL 83995460 (quoting Doug Horswill, Teck Cominco's Senior Vice-President of Environment and Corporate Affairs as saying that "to minimize releases, the company has spent more than $\$ 1$ billion (Cdn) in plant improvements over the last 20 years and has achieved environmental performance levels that meet the highest environmental and health criteria in Canada and the United States.").

${ }^{63}$ U.S. Has No Authority Over B.C. Smelter Operation, NAT'L PosT, Jan. 14, 2004, at FP07, available at 2004 WL 57228271 ("Teck Cominco reiterated an earlier offer to spend US\$13 million voluntarily for studies to assess human health and ecological concerns regarding Lake Roosevelt."); Letter from Williams \& Cardwell, supra note 61 (stating that Teck Cominco has offered to fund an estimated $\$ 13$ million study). 
submit to EPA jurisdiction or comply directly with CERCLA's requirements. ${ }^{64}$ Furthermore, Teck Cominco claims it has followed all the required Canadian environmental laws and complied with its Canadian permits. ${ }^{65}$ Teck Cominco correctly points out that the EPA wants to study further whether the pollution poses a risk to humans or to fish and wildlife. ${ }^{66}$ Against this backdrop, Teck Cominco has sought help from the Canadian government, ${ }^{57}$ who sent a diplomatic note to the U.S. State Department stating that the EPA does not have jurisdiction over Teck Cominco under the Superfund (CERCLA) laws. ${ }^{68}$

64 In April 2003, the EPA initiated informal discussions with Teck Cominco. The EPA sought to enter into an Agreed Administrative Order on Consent with Teck Cominco, whereby one of Teck Cominco's subsidiaries would conduct a study and investigation of the Lake Roosevelt site. On November 26, 2003, due to Teck Cominco's "unwillingness to address U.S. environmental and health standards in its proposed study and to meet the same conditions as U.S. companies must meet," negotiations broke down. Subsequently, in December 2003, the EPA issued a Unilateral Administrative Enforcement Order that demanded that Teck Cominco perform certain studies under CERCLA. Teck Cominco refused to comply with the demands of that letter. See generally Du Bey \& Sanscrainte, supra note 51, at 360. See also Teck Cominco Ltd. - Van Sun Says Teck Seeks Help Over EPA Demands, CAN. StOckwatCH, Nov. 28, 2003, available at 2003 WL 68818313 (stating that Teck Cominco "maintains that its participation, while in good faith, is voluntary and that the EPA has no authority to regulate the activity of a company in a foreign country"); Letter from David Thompson, Deputy Chairman and CEO of Teck Cominco Ltd., to the U.S. EPA (Nov. 14, 2003) (stating that Teck Cominco "is a Canadian company and its Trail metallurgical operations, which are the subject of this action, are located entirely in the Province of British Columbia. [Teck Cominco's] Trail operations are regulated under the laws of the Province of British Columbia and the laws of Canada. [Teck Cominco] and its Trail operations are not subject to CERCLA or the jurisdiction of the EPA.").

${ }^{65}$ News Conference Transcript, supra note 47 , at 3 . Generally Canadian environmental laws - despite Canada's "green" image - are not as strict as U.S. environmental laws. "Canadian industries generally don't have to meet the same level of discharge or performance standards as U.S. ones ... [and] Canadian companies, per average, emit about fifty percent more air and water pollution that U.S. companies." Stewart Elgie, Federal, State and Provincial Interplay Regarding Cross-Border Environmental Pollution, 27 CAN.U.S. L.J. 205, 206 (2001) (detailing further that these numbers come out to "[1.4] times as much ... on a per GDP basis").

${ }^{66}$ U.S. EPA REgION 10, DRAFT UPPER COLUMBIA RIVER SITE RI/FS SCOPING PLAN 1-1 \& 1-2 (Aug. 11, 2004) (stating that previous tests showed that further studies were required), available at http://yosemite.epa.gov/R10/CLEANUP.NSF/sites/UpperC (last accessed Feb. 17, 2005) .

${ }^{67}$ Teck Cominco Ltd. - Van Sun Says Teck Seeks Help Over EPA Demands, supra note 64 (stating that "Teck Cominco is appealing for help from Canada's Ministry of Foreign Affairs after negotiations with U.S. environmental regulators broke down this week over the details of a plan to clean up the Columbia River in Washington State").

${ }^{68}$ Du Bey \& Sanscrainte, supra note 51, at 360-61 (discussing Canadian government's response to EPA actions); Preusch, supra note 8 , at A8 (explaining that the "Canadian government also entered the fray with a formal diplomatic letter to the State Department 
In any case, having Teck Cominco or others take responsibility for the Trail smelter's alleged pollution, in the way the EPA wants it to, has proven difficult. ${ }^{69}$ Yet the conclusion of many environmentalists that Trail smelter discharges have caused serious long-term environmental harm has spurred action. ${ }^{70}$ In August 1999, the Colville Tribes petitioned the EPA to conduct a preliminary assessment to investigate the health and environmental risks of hazardous substances believed to be in the Upper Columbia River Basin near the Canadian border. ${ }^{71}$ The following year, the EPA granted the Colville Tribes' petition and began assessing the area. ${ }^{72}$ By October 2002, the EPA had completed its inspections and sampling, and determined that the Upper Columbia River-Lake Roosevelt area qualified for potential Superfund listing. ${ }^{73}$ That listing is a designation reserved for the country's most polluted sites. ${ }^{74}$

Friendly discussions and negotiations between the EPA and Teck Cominco ended in late 2003, without any agreement. In December 2003, the EPA issued a legal order - known as a Unilateral Administrative $\operatorname{Order}^{75}$ demanding that Teck Cominco complete a study consistent with the CERCLA laws. ${ }^{76}$ Teck Cominco refused to comply with the order, ${ }^{77}$ which under

asking that the environmental agency, in effect, back off.").

${ }^{69}$ For a general summary of the events surrounding the current Trail smelter dispute, see Du Bey \& Sanscrainte, supra note 51, at 359-61.

${ }^{70}$ For an account of the Colville Tribes' and the EPA's negotiations with Teck Cominco, see generally Du Bey \& Sanscrainte, supra note 51, at 358-62.

${ }^{71}$ EPA, supra note 14, at 2; see also U.S. EPA Region 10, Update on Upper Columbia River Sediment Investigation, EPA ENVIRONMENTAL FACT SHEET, Feb. 2003, at 3 (describing background of EPA investigation), http://yosemite.epa.gov/R10/CLEANUP.NSF/UCR/fact+sheets/\$FILE/uppercolumbia20030 303FS.pdf (last accessed Feb. 17, 2005).

72 EPA, supra note 14, at 2.

73 CERCLA - the Comprehensive Environmental Response, Compensation, and Liability Act - is a statute that holds companies strictly liable for release of hazardous substances. CERCLA established a National Priority List (NPL) to identify and remedy the country's most polluted sites, for which the federal Superfund may be accessed to pay clean-up costs. 42 U.S.C. $\S 9605(\mathrm{a})(8)(B)(2000)$ (authorizing the President also "to undertake or continue whatever interim remedial actions the President determines to be appropriate").

${ }^{74}$ For the various criteria upon which to determine whether a polluted site should be listed on the National Priority List, see Establishing Remedial Priorities, 40 C.F.R. $\S$ 300.425 (c) (2005) (discussing why it is necessary to create a priority of the most threatened or polluted sites).

75 The EPA issued the Unilateral Administrative Order under section 106(a) of CERCLA, which required Teck Cominco to perform a Remedial Investigation/Feasibility Study. See 42 U.S.C. $\S 9606$ (detailing how the President may order the Attorney General to take necessary measures to secure relief).

76 See EPA, supra note 14.

77 Id. at 2 (observing that because Teck Cominco did not comply the "EPA has decided to move ahead with the study according to Superfund laws and requirements"); see also 
CERCLA enabled the EPA to either: (1) sue to compel compliance; or (2) fund the study itself and take remedial action, and then later sue Teck Cominco for costs incurred. ${ }^{78}$ When the EPA did not sue, the Colville Tribes brought a citizen's suit. ${ }^{79}$ The suit, which the Colville Tribes filed in July 2004, seeks to compel Teck Cominco to comply with the EPA's Order. ${ }^{80}$ The suit also seeks a declaration that Teck Cominco violated CERCLA, and civil penalties amounting to as much as $\$ 27,500$ each day Teck Cominco fails to comply with the Order ${ }^{81}$ The Colville Tribes are not suing for their individual injuries, but rather they are acting as private attorneys general. ${ }^{82}$

The EPA's actions and the Colville Tribes' citizen's suit are unprecedented in many ways. First, the Colville Tribes "are the first Tribal government to file a petition for preliminary assessment under CERCLA."83 Second, the Trail Smelter dispute represents the first time the EPA has ever taken the extraordinary step of issuing a unilateral order to a Canadian company doing business solely in Canada. ${ }^{84}$ Third, the Colville Tribes' citizen's suit is the only known suit brought under CERCLA that attempts to apply CERCLA extraterritorially against a Canadian corporation. ${ }^{85}$ These three unprecedented

Complaint at $\$ 4.9$, Pakootas v. Teck Cominco Metals, Ltd., No. CV-04-0256-AAM (E.D. Wash. filed June 21, 2004) (stating the EPA is aware that Teck Cominco violated CERCLA).

${ }^{78}$ Complaint at 94.8 - 5.3, Pakootas v. Teck Cominco Metals, Ltd., No. CV-04-0256AAM (E.D. Wash. filed June 21, 2004) (seeking an order to enforce the UAO against Teck Cominco; see also Rowe, supra note 12, at B1.

79 See 42 U.S.C. $\S 9659$ (2000) (authorizing citizen's suits); Complaint at 6-7, Pakootas v. Teck Cominco Metals, Ltd., No. CV-04-0256-AAM (E.D. Wash. filed June 21, 2004) (claiming that the EPA has failed to enforce the UAO against Teck Cominco). In 1980, the U.S. Congress passed CERCLA, which provides the EPA with authority to facilitate the cleanup of sites contaminated by the past disposal of hazardous waste and other substances. See generally Comprehensive Environmental Response, Compensation, and Liability Act of 1980, 42 U.S.C. $\$ \S 9601-9675$ (2000); FREDERICK ANDERSON ET AL., ENVIRONMENTAL PROTECTION: LAW AND POLICY 568-603 (1983) (providing an overview of the Superfund program). CERCLA is known as the Superfund law, because at the time it was passed Congress established a fund of $\$ 8.5$ billion to finance the cleanup of contaminated sites.

${ }^{80}$ Complaint at 1, 5-7, Pakootas v. Teck Cominco Metals, Ltd., No. CV-04-0256-AAM (E.D. Wash. filed June 21, 2004).

${ }^{81}$ See id. at 7 (praying for declaratory relief and civil penalties); see also 42 U.S.C. $\S$ 6906 (2000) (allowing for civil penalties for violations of CERCLA).

82 See Rowe, supra note 12, at B1 (quoting tribes spokesperson as saying "[the tribe] would not gain personally from the lawsuit"). See generally DANIEL RIESEL, ENVIRONMENTAL ENFORCEMENT: CiVIL AND CRIMINAL $\$ 1.06$ (14th release, 2004) (discussing the nature of citizen suits).

83 Du Bey \& Sanscrainte, supra note 51 , at 359 n.161.

${ }^{84}$ Teck Cominco Ltd., Van Sun says Teck Threatened with EPA Fines, CAN. STOCKWATCH, Dec. 12, 2003, available at 2003 WL 68821258 (reporting that Teck could face legal action by the EPA to recover costs for studies).

${ }^{85}$ See Washington State Tribe, supra note 17 (articulating that it "is believed to be the 
steps all raise the same issue: whether the EPA can force a Canadian company, governed by Canadian environmental law, to comply with the terms of CERCLA.

\section{B. The Continuing and Increasing Significance of U.S.-Canada Transboundary Pollution}

Although the Colville Tribes' lawsuit is the first citizen's suit that attempts to apply CERCLA extraterritorially, many other cross-border water pollution disputes exist between Canada and the United States. Other contentious environmental water conflicts currently include:

- North Dakota's plan to drain waters from Devils Lake to stop repeated flooding, which Manitoba fears could pollute the Red River and Lake Winnipeg. ${ }^{86}$

- A disagreement between Alberta and Montana over use of the Milk and St. Mary rivers, where Montana contends it receives less than its fair share of water from those rivers. ${ }^{87}$

first case of Americans suing a Canadian company under U.S. Superfund law"). Telephone conversations with the Canadian Department of Foreign Affairs and International Relations confirmed, from the Canadian perspective, the unprecedented nature of the lawsuit. Telephone Interview with Sameer Ahmed, Canadian Department of Foreign Affairs and International Relations (Aug. 2, 2004).

${ }^{86}$ See Sheryl A. Rosenberg, A Canadian Perspective on the Devils Lake Outlet: Towards An Environmental Assessment Model for the Management of Transboundary Disputes, 76 N.D. L. REV. $817,817-18$ (2000) (discussing the environmental concerns over a proposal to build an outlet from Devils Lake into the Cheyenne River to prevent flooding in the Devils Lake region, which will impact both North Dakotan and Manitoban residents). See generally DeNeen L. Brown, Devils Lake Too 'Sacred' for Drainage: Elder from North Dakota Tribe Opposed to Controversial Project, WINNIPEG FREE PRESS, June 30, 2004, at B10, available at 2004 WL 81966509 (discussing how "Canadian officials have joined with environmental groups and native Americans to raise concerns about plans by the federal and state governments to build drainage outlets, intended to reduce the lake's flooding."); DeNeen L. Brown, 'Sacred' Waters, Unholy Controversy; Dakota Tribe Fights Plan to Drain Lake, WASH. POST, June 25, 2004, at A14, available at 2004 WL 82765093 (describing Canada-U.S. dispute over Devils Lake); Blake Nicholson, Manitoba to Sue Over DL Outlet; U.S. Groups Also Would Join Lawsuit if Issue Doesn't Reach IJC, GRAND FORKS HERALD (N.D.), June 17, 2004, available at 2004 WL 81744358 (explaining that "Manitoba officials say they plan a federal lawsuit over North Dakota's Devils Lake outlet project if their concerns are not addressed by an international panel that reviews boundary water issues").

${ }^{87}$ See Michael Byers, Commentary, Don't Water Down Canada's Deal: A Tale of Two Rivers Highlights the Cross-border Competition for a Precious Resource, Says International Law Expert, GLOBE \& MAIL (Toronto), July 26, 2004, at A13 (discussing the cross-border dispute and the importance of the Milk and St. Mary rivers to Canada); Jared Miller, Montanans, Canadians Make Push for Water Apportionment, GREAT FALLS TRIBUNE (Mont.), July 24, 2004, at 7A (discussing public hearings held before International Joint Commission to discuss how the two countries share the Milk and St. Mary rivers water); 
- British Columbia's intent to auction off rights to drill for methane on nearly 100,000 acres near the Flathead and Elk rivers, which environmentalists believe will cause significant toxic waste water to flow into Montana. ${ }^{88}$

- A dispute over the Tulsequah Chief base metals mine in northeastern British Columbia in a watershed that straddles British Columbia and Alaska that could impact fisheries and cause environmental damage. ${ }^{89}$

- Canada's refusal to export fresh water to the United States based on environmental and other concerns. ${ }^{90}$

Other transboundary concerns include the water quality of the Great Lakes, ${ }^{91}$ acid rain, ${ }^{92}$ air pollution, ${ }^{93}$ hazardous waste disposal, ${ }^{94}$ and depletion

Montana Wants Bigger Share of Water from Two Rivers that Flow into Alberta, CAN. PRESS, April 13, 2004, available at 2004 WL 75646501 (discussing the dispute over the Milk and St. Mary rivers).

${ }^{88}$ See George Koch and John Weissenberger, Fomenting Mischief in B.C., NAT'L PosT (Toronto), Aug. 4, 2004, at A13, available at 2004 WL 88250497 (describing the nature of the dispute over methane drilling); Todd Wilkinson, U.S. Clashes with Canada Over Pollution at the Border; Shared Rivers Carry Toxic Troubles Both Ways, CHRISTIAN SCI. MONITOR, Aug. 6, 2004, at 2 (mentioning B.C.'s plan to auction off drilling rights); see also Mark Hume, B.C. Resource Developments Under Fire: U.S. Secretary of State Asked to Intervene in Movement to Halt Plans for Coal Mine, GlobE \& MAIL (Toronto), May 10, 2004, at A9 (reporting that U.S. Secretary of State, Colin Powell, has been asked to intervene in the dispute and quoting a Montana Senator saying that if the B.C. government goes ahead with the mining, "[t]hey are asking for a fight").

${ }^{89}$ See Wilkinson, supra note 88 , at 1 (discussing, among other water conflicts, the Tulsequah Chief mine dispute).

90 See, e.g., Leo Lewis, Parched U.S. Demands Rights to Canada's Water, INDEPENDENT (London), Aug. 12, 2001, at 3, available at 2001 WL 23545050 (discussing the "bitter feud" over Canada's refusal to export water to the U.S. given serious environmental concerns, and Canada's belief that the dispute will end in litigation); Robert Lewis, A Hot Issue the Government Ignored (The Issue of Canada 's Export of Water to the U.S.), MACLEAN's, Oct. 25, 1999, at 2, available at 1999 WL 100237780 (arguing that the "export of Canada's [water] is going to be one of the hot issues of the next decade"); Put a Cork In It: U.S. Government Proposes Canada Export Water to American South, MACLEAN's, July 30, 2001, at 12, available at 2001 WL 9811832 (discussing U.S. desire to have Canada export fresh-water to the U.S. and Canadian opposition based on environmental concerns).

91 See generally INTERNATIONAL JOINT COMMISSION, CANADA AND THE UNITED STATES 2003 ANNUAL REPORT 1-2 (2003) (summarizing the activities of the International Joint Commission in 2003 under the Great Lakes Water Quality Agreement), http://www.ijc.org/php/publications/pdf/ID1555.pdf (last accessed Feb. 1, 2005).

92 The problem of acid rain is a continuing one. For recent discussions of the acid rain problem, see Bernard C. Melewski, Acid Rain and the Adirondacks: A Legislative History, 66 ALB. L. REV. 171, 172-78 (2002) (describing the problem and legislative response to combat acid rain); Jennifer Yelin-Kefer, Warming Up to an International Greenhouse Gas Market: Lessons From The U.S. Acid Rain Experience, 20 STAN. ENVT'L. L.J. 221, 222-25 
of shared natural resources. ${ }^{95}$ Moreover, observers lament how U.S.-Canadian relationships over transboundary water disputes are becoming "increasingly protracted and difficult" to resolve. ${ }^{96}$

(2001) (introducing economic proposals to remedy the problem). See also Joel A. Gallob, Birth of the North American Transboundary Environmental Plaintiff: Transboundary Pollution and the 1979 Draft Treaty for Equal Access and Remedy, 15 HARv. ENVTL. L. REV. 85, 132-33 (1991) (discussing the detrimental impacts of acid rain in Canada and the United States).

93 See, e.g., AGs Press Canada Regulators to Reduce Emissions from Ontario Coal Stations, ELECTRIC UTIL. WK., May 5, 2003, at 20, available at 2003 WL 11143899 (discussing petition filed by New York, Connecticut, and Rhode Island Attorneys General, under an environmental side agreement to NAFTA, calling for Canada to reduce emissions from Ontario coal plants).

${ }^{94}$ See Robert E. Cattanach, Jr. \& Peter V. O'Connor, Environmental Concerns Raised by the Canada-United States Free Trade Agreement, 18 WM. Mitchell L. REV. 461, 479-82 (1992) (outlining the issues regarding hazardous waste).

95 See generally John Carroll, Water Resource Management as an Issue in Environmental Diplomacy, 26 NAT. RESOURCES J. 207, 209 (1986) (finding that there are "water quality issues ... along the entire length of the [United States/Canadian] border"); Cattanach \& O'Connor, supra note 94, at 470-78 (discussing Canada-U.S. transboundary environmental issues); Gallob, supra note 92, at 86 (discussing and arguing that the international efforts to combat transboundary water pollution between the United States and Canada have been inadequate); Timothy M. Gulden, Transfrontier Pollution and the International Joint Commission: A Superior Means of Dispute Resolution, 17 Sw. U. L. REV. 43, 57 (1987) (describing past transboundary water disputes between the United States and Canada, including "Great Lakes water quality, hazardous wastes in the Niagara River, [and] raising the High Ross Dam on the Skagit River in British Columbia," among other disputes); John Knox, Federal, State and Provincial Interplay Regarding CrossBorder Environmental Pollution, 27 CAN.-U.S. L.J. 199, 199-203 (2001) (observing that "one result of having a five-thousand-mile border is that the United Sates and Canada have a lot of trans-boundary environmental problems").

For some specific examples of recent disputes, see Clarke Canfield, Disputed U.S.Canada Waters Spur Fears of Lobster War, AsSOC. PRESS NewswIRES, Sept. 15, 2003 (discussing ocean boundary dispute fueled by fisherman arguing over lobster); Karen Dorn Steele, B.C. Fuming After Summer of Smoky Skies, SpOKESMAN-REv. (Spokane), Nov. 9, 2003, at Al (discussing how Canadians are upset over field burning in Idaho that causes heavy smoke to cross the border).

96 W. R. Derrick Sewell \& Albert E. Utton, "Getting to Yes" in United States-Canadian Water Disputes, 26 NAT. RESOURCES J. 201, 201-03 (1986) (outlining the difficulties in reaching a compromise between the nations on these issues). Similar transboundary pollution issues exist between the United States and Mexico. Although beyond the scope of this Article, these disputes raise similar legal questions. See John H. Knox, The CEC and Transboundary Pollution, in GREENING NAFTA: THE NORTH AMERICAN COMMISSION FOR Environmental CoOperation 80, 80 (David L. Markell \& John H. Knox eds., 2003) (noting that "San Diegans complain that sewage from Tijuana befouls their beaches; Texans accuse power plants in Coahuila of clouding the skies over Big Bend National Park; Mexicans protest against proposals to site waste disposal facilities in South Texas.... 
Not only do many transboundary pollution disputes currently exist, their numbers are expected to increase. The Canadian Department of Foreign Affairs and International Relations believes that cross-border water disputes are one of the most significant diplomatic challenges the United States and Canada will face in the coming years. ${ }^{97}$ Environmental law experts share this view. ${ }^{98}$ As one commentator explains: "Over the past century, no natural resource along the 5,000-mile border has left the U.S. and Canada more united - and divided - than water." 99

This expected increase of transboundary disputes is hardly surprising. Canada and the United States "share an extensive border that includes some 150 rivers and lakes - a situation that has 'provided ample opportunity for the generation of international environmental disputes." 100 Moreover, the amount

Moreover, thousands of sources, on both sides of the border, pollute shared bodies of water such as the Great Lakes and the Rio Grande and shared airsheds such as that over El Paso and Ciudad Juárez."). See generally Nivea R. Berrios-Colón, Transboundary Movement of Hazardous Waste from Mexico to the United States: EPA's Authority to Enforce RCRA Requirements Against Mexican Maquiladoras, 8 ENVTL. LAW. 1, 71-73 (2001) (concluding that U.S. environmental agencies should bring U.S. enforcement actions against Mexican maquiladoras who allegedly violate RCRA).

A particularly contentious dispute involves the Environmental Health Coalition's assertion that the EPA has jurisdiction and extraterritorial authority related to cleaning up of pollution of the New River, caused allegedly by maquiladors. Maquiladoras are Mexican assembly plants, generally owned by non-Mexican corporations, that manufacture finished goods for export to the United States. See, e.g., Elia V. Pirozzi, Compliance Through Alliance: Regulatory Reform and Application of Market-Based Incentives to the United States-Mexico Border Region Hazardous Waste Problem, 12 J. ENVTL. L. \& LITIG. 337, $364-$ 65 (1997) (providing a brief factual account of the dispute between the U.S. and Mexico); see also Jennifer M. Siegle, Comment, Suing U.S. Corporations In Domestic Courts for Environmental Wrongs Committed Abroad Through the Extraterritorial Application of Federal Statutes, 10 U. MuAmI Bus. L. REV. 393, 421 (2002) (explaining the alleged violation and settlement).

97 Telephone Interview with Sameer Ahmed, Canadian Department of Foreign Affairs and International Relations (Aug. 2, 2004).

98 See, e.g., Cooper, supra note 20, at 312 (explaining that "[i]n a shrinking world ... international environmental disputes are inevitable"); Wendy Stueck, Water Tension Rising Between Canada and U.S. - Issues Surfacing As Population Growth Puts More Pressure on Shared Lakes and Rivers, GLOBE \& MAIL (Toronto), May 17, 2004, at B7 (quoting an expert that observes: "Water issues between the U.S. and Canada are becoming increasingly central to our relations - and tensions are increasing."); $c f$. Hanson et al., supra note 20, at 137-38 (stating that the "increasing integration of the Canadian and United States economies, a process accelerated by the Canada/United States Free Trade Agreement, and the tightening of environmental standards on both sides of the border, is likely to result in increased environmental litigation between Canadian and United States parties.").

99 Wilkinson, supra note 88 , at 1.

100 Gallob, supra note 92, at 112 (citing Cooper, supra note 20, at 249); see also David G. Lemarquand, Preconditions to Cooperation in Canada-United States Boundary Waters, 
of trade between the U.S. and Canada, which under conventional thinking is a significant cause of environmental harm, ${ }^{101}$ is growing. The trading relationship between the United States and Canada represents the largest bilateral flow of income, goods, and services in the world. ${ }^{102}$ Nearly $\$ 1.1$ billion in goods cross the border on a daily basis, while U.S.-Canada trade in services, cross-border investments, and tourism surpasses $\$ 42$ billion yearly. ${ }^{103}$ According to the U.S. State Department, trade in merchandise and services between the two countries has grown by $142 \%,{ }^{104}$ or an average of $11 \%$ each year, since NAFTA's enactment in 1994. ${ }^{105}$ Furthermore, business between Canada and the U.S. is expected to double by $2008 .{ }^{106}$ An increase in

26 NAT. RESOURCES J. 221, 221 (1986) (finding that along a "total 4,800 mile length of the boundary nearly 300 lakes, rivers and streams flow along or across the border . . . [and that] [c]ontention over these waters has been a fact of bilateral relations dating from the last century and will certainly remain significant in the future").

101 See Michael Robins, The North American Free Trade Agreement: The Integration of Free Trade and the Environment, 7 TEMP. INT'L \& COMP. L.J. 123, 125 (1993) (arguing that the increased trade and industrialization brought by NAFTA will have "serious detrimental ecological and environmental effects"); $c f$. PIERRE MARC JOHNSON \& ANDRE BEAULIEU, THE ENVIRONMENT AND NAFTA: UNDERSTANDING AND IMPLEMENTING THE NEW CONTINENTAL LAW 37, 40-47 (1996) (debunking conventional "argument that international trade promotes economic growth and that such economic growth intrinsically threatens the environment" but observing that trade liberalization may place downward pressure on environmental standards).

102 See Rebecca Jannol et al., Migration Policy Institute, U.S.-Canada-Mexico FACT SHeET ON TRADE AND Migration 1, 1 (2003) (providing trade and migration information for the U.S., Canada, and Mexico), http://www.migrationpolicy.org/pubs/three_us_mexico_canada_trade.pdf (last accessed Feb. 17, 2005).

${ }^{103}$ Roger F. Noriega, Assistant Secretary of State for Western Hemisphere Affairs, Remarks to Economic Club of Toronto: Trade \& the Canada-U.S. Border (Mar. 29, 2004) (highlighting the interdependence of the U.S. and Canada as trade partners), at $\mathrm{http}: / / \mathrm{www} . s t a t e . g o v / \mathrm{p} / \mathrm{wha} / \mathrm{rls} / \mathrm{rm} / 31949 . \mathrm{htm}$ (last accessed Feb. 17, 2005); see also Robert Hage, The New Reality In Canada/U.S. Relations: Reconciling Security and Economic Interests and the "Smart Border Declaration", 29 CAN.-U.S. L.J. 21, 24 (2003) (explaining that over CDN $\$ 2$ billion in trade crosses the border daily). Until recently, the MichiganOntario trade exchange was greater than that between the U.S. and Japan. James J. Blanchard, Overview of Canada/U.S. Dispute Management and Settlement: Where We Are In Terms of Successes and Failures - A U.S. Perspective, 26 CAN-U.S. L.J. 11, 12 (2000) (observing also that America receives as much oil each year from Canada as Saudi Arabia).

104 U.S. DEP'T OF STATE, BACKGROUND NOTE: CANADA (2004) (providing facts on Canada and U.S.-Canada relations), at http://www.state.gov/r/pa/ei/bgn/2089.htm (last accessed Feb. 17, 2005).

105 Hage, supra note 103, at 24-25 (finding that in "the post-NAFTA 90's, Canada-U.S. trade has grown by 11 percent per year").

106 John W. McCurry. Natural Catalysts: While 911 Slowed Development, the Rebound Is Under Way Along North America's Borderlands, SITE SELECTION MAG., July 2002 (referencing U.S.-Canada trade as evidence of economic recovery), at 
environmental transboundary disputes can also be expected because of growing population near the border. Approximately ninety percent of all Canadians live within a hundred miles of the border, ${ }^{107}$ and Canada's population has doubled over the last half century. ${ }^{108}$ The number of people crossing the border is significant too: 200 million each year, or more than half a million people every day. ${ }^{109}$

A related issue, which may lead to tension between the two countries, is the growth of cross-border hazardous waste transportation. Hundreds of thousands of tons of hazardous waste cross the border yearly, ${ }^{110}$ and in recent years the amounts have increased dramatically. 11 As the amount of trade has grown, the amount of toxic pollution in waterways between the U.S. and Canada has also increased, even as other types of pollution have decreased. ${ }^{112}$

\section{THE LiMITATIONS OF DOMESTIC LAW}

Although transboundary disputes between Canada and the United States

http://www.siteselection.com/features/2002/jul/borders (last accessed Feb. 17, 2005).

107 JANNOL ET AL., supra note 102, at 1 (citing DEMETRIOS PAPADEMETRIOUS \& DEBORAH W. MEYERS, CAUGHT IN THE MiddLE: Border COMMUNities In AN ERA OF Globalizations $62(2001))$.

108 Statistics Canada, 2001 Census analysis Series: A Profile of Canadian POPULATION - WHERE WE LIVE 1 (2001) (charting Canadian population trends and other statistics), at http:/geodepot.statcan.ca/Diss/Highlights/Tables_e.pdf (last accessed Feb. 17, 2005).

109 Noriega, supra note 103 (mentioning the large amount of migration between the two nations); see also Hage, supra note 103, at 24 ("Fifty thousand people cross the border every day; and this is the statistic that I find so overwhelming, 200 million border crossings by people every year.").

110 See Hanson et al., supra note 20, at 138 (explaining that in 1990, 137,000 tons of hazardous waste were imported into the U.S. from Canada, while the U.S. exported approximately 143,000 tons to Canada).

111 See Janine Ferretti, Energy. The Environment And Natural Resources In The Canada/U.S. Context, 28 CAN.-U.S. L.J. 81, 83 n.13 (2002) (explaining that there has been a $400 \%$ increase in the import of hazardous waste from the United States to Canada since NAFTA was implemented); see also Francisco S. Nogales, The NAFTA Environmental Framework, Chapter 11 Investment Provisions, and the Environment, 8 ANN. SURV. INT'L \& COMP. L. 97, 129-30 (2002) (citing a study that suggests that "U.S. waste exports to Canada and Quebec have dramatically increased ... and that development of higher standards to protect human health and the environment has been constrained"); Katherine Yung, Progress and Pitfalls; NAFTA Proves Trade Goals, Environment Not a Mismatch, DALLAS MORNING NEWS, July 13, 2003, at 2 (explaining that since the enactment of NAFTA, hazardous waste imports to Canada from the U.S. increased nearly five-fold).

112 Bruce Geiselman, For Better, Worse: U.S.-Canada Air Cleaner, But Land and Water More Toxic, Study Says, WASTE NEWS, June 10, 2002, at 1, available at 2002 WL 10367451 (discussing a report concluding that "manufacturers cut emissions of toxic chemicals into the air by 25 percent during a five-year period ending in 1999, but the decrease was largely offset by increases in toxic waste released on land and into the water"). 
(like the Trail smelter conflict) are intrinsically international in nature, U.S. groups and agencies searching for solutions to transboundary pollution problems usually think in domestic terms. Indeed, in recent years, Americans and Canadians have become "accustomed to asserting their rights and seeking redress for wrongs in each other's courts." 113 This may partly be attributable to legal scholars who often exalt national adjudication as the most effective means of obtaining relief. ${ }^{114}$ It may also be attributed to opportunistic trial attorneys, who benefit from filing cases locally. Whatever its cause, this focus on national adjudication is certainly evident with the current Trail smelter dispute, where the EPA and the Colville Tribes, on the EPA's behalf, seek to hold Teck Cominco responsible in a U.S. court for U.S. law violations. ${ }^{115}$

The benefits of national adjudication, however, are overstated, and the belief that the United States government (or private citizens suing under citizen's suit provisions) can use domestic regulatory laws to meaningfully regulate or resolve transboundary pollution disputes may be myopic. It is true, as discussed below, that the United States as a litigant could well overcome various jurisdictional hurdles that at one time would have prevented it from obtaining relief for transboundary pollution in a U.S. court. ${ }^{116}$ Contrary to what many might believe at first blush, U.S. courts are often willing to exercise

113 Wang, supra note 20, at 182 (explaining the reliance upon domestic law in U.S.Canadian disputes); see also Cooper, supra note 20, at 272-73 (mentioning the impact of national litigation in international conflicts).

114 See, e.g., J.G. Lammers, Pollution of International Watercourses: A Search FOR SUBSTANTIVE RULES AND PRINCIPLES OF LAW 49 (1984) ("Indeed the obstacles may be such that instead of having to resort to its own courts and all the practical advantages which such a resort would imply, the plaintiff would still be better off instituting proceedings against the defendant in the courts of the country of origin of the interference"); $c f$. John $\mathrm{S}$. Willems, Shutting the U.S. Courthouse Door?: Forum Non Conveniens in International Arbitration, Disp. RESOL. J., Aug.-Oct. 2003, at 54, 56 ("Litigants are attracted to the high quality of U.S. courts, the willingness of U.S. courts to exercise jurisdiction over international disputes, and, rightly or wrongly, the belief that U.S. courts are ready to award large sums of damages."). The preference for domestic litigation is great enough that in 1982, the U.S. National Conference of Commissioners on Uniform State Laws and the Canadian Uniform Law Conference drafted a Uniform Transboundary Pollution Reciprocal Access Act. That Act's key provision would allow Canadians access to U.S. courts, and Americans access to Canadian courts, for transboundary pollution claims. The Act has not been widely adopted, however, and is rarely utilized. See Knox, supra note 96, at 87-88.

115 See supra Part I.A.2 (detailing the legal dispute between Teck Cominco, the EPA, and the Colville Tribes).

116 Courts have been struggling for years to define the appropriate limitation on U.S. states' extraterritorial jurisdiction. See generally Gary B. Born, A Reappraisal of the Extraterritorial Reach of U.S. Law, 24 LAW \& POL'Y INT'L BUS. 1 (1992); Allen Rostrom, The Supreme Court. The Gun Industry and the Misguided Revival of Strict Territorial Limits on the Reach of State Law, 2003 MiCH. ST. DETROIT C.L. L. REV. 115, 123-24 (observing that the strict territorialist idea, that state authority is limited to only those things that occurred within the state's borders and nothing else, has long been abandoned). 
jurisdiction over such international-type disputes. In the last decade, Canadian courts have also willingly enforced U.S. judgments obtained against Canadian companies. In many ways, the expansion of jurisdiction over foreign companies is only the latest step in a steady expansion of the modern rules of jurisdiction and tort liability. ${ }^{117}$ But such a result is problematic. In disputes, like the Trail smelter, the resort to national adjudication will lead to increasing discord between the two nations.

\section{A. The Demise of Territorialism and Judicial Self-Restraint: The Application of U.S. Laws to Canadian Companies}

The EPA's attempt to recover in a U.S. court for harm caused by transboundary pollution is a new phenomenon. ${ }^{118}$ Historically, such suits have been unlikely to succeed because of jurisdictional difficulties, including the presumption against extraterritorial application of domestic laws. ${ }^{119}$ Domestic litigation was also somewhat futile because of practical difficulties in enforcing any judgment obtained.120 But things have changed. Modern conceptions of jurisdiction are broad. Although a detailed analysis of all the jurisdictional and enforcement issues facing groups like the EPA or the Colville Tribes who file domestic suits against foreign companies is beyond the scope of this Article, the traditional territorial barriers to relief no longer exist, or at least are not as insurmountable as they once were.

\section{Obtaining Personal Jurisdiction Over Canadian Companies Under the} Effects Test

An initial hurdle that the EPA, or a citizen's group, would historically have difficulty overcoming - when filing a regulatory action against a foreign company that does not do business in, or have other significant connections with, the United States - would be to convince a U.S. court that it has personal jurisdiction over that foreign company. Jurisdiction, for the longest of times, ended at the border. Over the last thirty years, however, the law has developed

117 The academic community vigorously debates whether jurisdictional rules have run amok in the United States, creating expansive tort and environmental liability. This issue is not the focus of this Article, and this article is not an attempt to engage in this debate.

118 See generally ENVIRONMENTAL LAW INSTITUTE, STRENGTHENING U.S.-MEXICO Transboundary ENVIRONMENTAL ENFORCEMENT: LEgal STRATEgIES FOR PREVENTING THE USE OF THE BORDER AS A SHIELD AGAINST LIABILITY 10-11 (2002) (generally discussing new and innovative ways of using domestic laws to regulate cross-border pollution in the context of Mexico-U.S. relations); Gerald F. George, Over the Line - Transboundary Application of CERCLA, 34 ENVTL L. REP. 10275, 10275 (2004) (explaining that in the last two years, the EPA has begun to focus more heavily on transboundary enforcement).

119 WEISS ET AL, supra note 4, at 262 (discussing traditional jurisdictional obstacles to private remedies, in the context of discussing the Trail Smelter Arbitration); HUNTER ET AL., supra note 2, at 511 .

120 See infra Part II.A.3. 
in such a way that so long as a defendant's activities have a substantial harmful effect in the United States, a U.S. court will likely accept jurisdiction.

The Due Process Clause of the United States Constitution permits the exercise of specific jurisdiction ${ }^{121}$ only on claims that "arise out of or relate to" a defendant's contacts with the forum. ${ }^{122}$ The "constitutional touchstone" for whether exercise of specific personal jurisdiction comports with due process "remains whether the defendant purposefully established 'minimum contacts' in the forum [s]tate." 123 The "minimum contacts" requirement "protects a defendant, who has no meaningful contact with a state," from the burden of: (1) defending a lawsuit far from home; and (2) litigating in a forum where the "substantive and procedural laws may be quite different from those with which the litigant is familiar." 124

In determining whether specific jurisdiction exists, a court's inquiry is twofold. First, the court must determine whether the defendant has such minimum contacts with the forum state "that he [or she] should reasonably anticipate being haled into court there." 125 Within this inquiry a court must determine whether the defendant "purposefully directed" its activities toward the forum state, ${ }^{126}$ and whether the plaintiff's claim arises out of or results from "actions

121 Burger King Corp. v. Rudzewicz, 471 U.S. 462, 417-72 (1985) (explaining that a court's exercise of specific jurisdiction over an out-of-state defendant is constitutional under the Due process Clause if the defendant's contacts with the forum state are sufficient to give him "fair warning" of his amenability to suit there). General jurisdiction, in contrast, exists whenever a defendant has "continuous and systematic contacts with the forum state sufficient to justify the state's exercise of judicial power with respect to any and all claims." Kerry Steel, Inc. v. Paragon Indus., 106 F.3d 147, 148 (6th Cir. 1997) (distinguishing specific personal jurisdiction from general personal jurisdiction).

122 Helicopteros Nacionales de Colombia, S.A. v. Hall, 466 U.S. 408, 414 n.8 (1984) (stressing that a court may exercise specific personal jurisdiction over a nonresident corporate defendant if the controversy "arises out of" the defendant's contacts with the state).

${ }^{123}$ Asahi Metal Indus. Co. v. Super. Ct., 480 U.S. 102, 108-09 (1987); see also Int'l Shoe Co. v. Washington, 326 U.S. 310,316 (1945) (stating that a court may constitutionally subject a nonresident defendant to specific personal jurisdiction if the court upholds "traditional notions of fair play and substantial justice" by requiring that the defendant have "certain minimum contacts" with the forum state).

124 OMI Holdings, Inc. v. Royal Ins. Co. of Can., 149 F.3d 1086, 1090 (10th Cir. 1998); see also World-Wide Volkswagen Corp. v. Woodson, 444 U.S. 286, 291 (1979) (explaining that the "minimum contacts" requirement protects a defendant from the burdens of litigating in a distant forum and ensures that a state does not use its courts to encroach on another state's sovereignty).

125 World-Wide Volkswagen, 444 U.S. at 297 (emphasizing that a defendant's minimum contacts with a forum state be such that the defendant has "some minimum assurance as to where [those contacts] will and will not render [him] liable to suit).

126 Burger King, 471 U.S. at 472 (stating that the "purposefully directed" tests satisfies the due process requirement); Keeton v. Hustler Magazine, Inc., 465 U.S. 770, 774 (1984) (upholding personal jurisdiction over a defendant that "purposefully directed" its activities 
by the defendant himself that create a substantial connection with the forum [s]tate." 127 In the landmark decision Calder v. Jones, the U.S. Supreme Court found that a defendant satisfies these requirements if the defendant commits an intentional act expressly aimed at the forum that causes harm, the "brunt" or focus of which the defendant knows is likely to be suffered in the forum. ${ }^{128}$ Second, if the defendant has sufficient minimum contacts, a court must consider whether the exercise of personal jurisdiction over the defendant offends "traditional notions of fair play and substantial justice." 29 This second inquiry, whether assertion of jurisdiction is reasonable, necessarily is related to the first inquiry. 130

In the Trail smelter and similar transboundary pollution disputes, Canadian corporations, like Teck Cominco, will likely be found to have minimum contacts with the forum (here, Washington State) into which they released the pollution. First, the Trail smelter litigation "arises out" of the pollution Teck Cominco placed in the Columbia River. It is the very subject of the

at the forum state through magazine circulation).

127 Asahi, 480 U.S. at 109; see also Hanson v. Denckla, 357 U.S. 235, 253 (1958) (explaining that when a corporation has "purposefully availed itself" of the privilege of conducting activities within the forum State, it has clear notice that it is subject to suit there).

${ }^{128}$ Calder v. Jones, 465 U.S. 783, 789-90 (1984); see also Gordy v. Daily News, L.P., 95 F.3d 829, 834 (9th Cir. 1996) (stressing that the Calder test does not ask categorical or mechanical questions, but focuses on the relationship among the defendant, forum, and particular factual circumstances); cf. Core-Vent Corp. v. Novel Indus. AB, 11 F.3d 1482, 1486 (9th Cir. 1994) (finding personal jurisdiction improper where it was unclear whether the defendant's actions were directed at the forum state or the brunt of the harm was suffered in the forum state). As one court states, "Calder stands for the proposition that purposeful availment is satisfied even by a defendant 'whose only 'contact' with the forum state is the 'purposeful direction' of a foreign act having effect in the forum state."' Dole Food Co. v. Watts, 303 F.3d 1104, 1111 (9th Cir. 2002) (quoting Haisten v. Grass Valley Med. Reimbursement Fund, 784 F.2d 1392, 1397 (9th Cir. 1986)); see also Bancroft \& Masters, Inc. v. Augusta Nat'l, Inc., 223 F.3d 1082, 1087 (9th Cir. 2000) ("In Calder, the Supreme Court held that a foreign act that is both aimed at and has effect in the forum state satisfies the purposeful availment prong of the specific jurisdiction analysis.").

129 Asahi, 480 U.S. at 113 . In determining whether exercise of jurisdiction is so unreasonable as to violate "fair play and substantial justice," a court will consider: (1) the burden on the defendant; (2) the forum state's interest in resolving the dispute; (3) the plaintiff's interest in receiving convenient and effective relief; (4) the interstate judicial system's interest in obtaining the most efficient resolution of controversies; and (5) the shared interest of the several states in furthering fundamental substantive social policies. Id.

${ }^{130}$ See Metropolitan Life Ins. Co. v. Robertson-Ceco Corp., 84 F.3d 560, 568 (2d Cir. 1996); Ticketmaster-N.Y., Inc. v. Alioto, 26 F.3d 201, 210 (1st Cir. 1994) (remarking that the "reasonableness prong of the due process inquiry evokes a sliding scale: the weaker the plaintiff's showing on [minimum contacts], the less a defendant need show in terms of unreasonableness to defeat jurisdiction"). 
litigation. ${ }^{131}$ Second, courts will likely find that specific jurisdiction exists under the Calder effects test. Teck Cominco committed an intentional act: the release of slag into the Columbia River. ${ }^{132}$ The release was expressly aimed at the forum state, because it was placed in a river Teck Cominco knew would carry the slag into the United States, less than seven miles away. ${ }^{133}$ Teck Cominco knew the river would carry the slag downstream to the U.S. because it had been happening for decades. ${ }^{134}$ If the slag dumping caused harm, Teck Cominco knew that harm would be felt in the United States. ${ }^{135}$ For purposes of jurisdiction, a violation of CERCLA is considered tortious activity. ${ }^{136}$

Not only will a court likely consider Teck Cominco to have minimum contacts with Washington, a court will likely find the exercise of jurisdiction reasonable. Admittedly, when dealing with foreign corporations, because the burden of mounting a defense can be "unique," "[g]reat care and reserve should be exercised" when extending personal jurisdiction over that corporation. ${ }^{137}$ In such cases, the court must balance "the burden on the defendant, the interests of the forum state, and the plaintiff's interest in obtaining relief."138 Nevertheless, in recent years U.S. courts have considered the burden on Canadians defending in the United States light, and thus

131 See Complaint at 3-4, Pakootas v. Teck Cominco Metals, Ltd., No. CV-04-0256AAM (E.D. Wash. filed June 21, 2004).

132 Id. (asserting that Teck Cominco generated millions of tons of toxic slag and disposed of it by releasing it into the Columbia River over an extended time).

133 See supra Part I.A.1.

134 Complaint at 3-4, Teck Cominco (No. CV-04-0256-AAM) (asserting that Teck Cominco dumped slag into the Columbia river from the early 1900s until 1995).

135 See, e.g., Brainerd v. Governors of the Univ. of Alberta, 873 F.2d 1257, 1258-60 (9th Cir. 1989) (finding that an Arizona court had specific personal jurisdiction over a Canadian defendant who made allegedly defamatory statements during telephone calls placed to the defendant from Arizona to Canada).

136 See Nielsen v. Sioux Tools, Inc., 870 F. Supp. 435, 438-39 (D. Conn. 1994) (concluding that "defendant's alleged contamination of soil and groundwater may be construed as 'tortious conduct"' for purposes of jurisdiction); see also U.S. v. Conservation Chem. Co., 619 F. Supp. 162, 245 (W.D. Mo. 1985) (stating that "the release of a hazardous substance creating an imminent danger to ... property and the environment is in the nature of a tort" for purposes of establishing long arm jurisdiction).

137 Asahi Metal Indus. Co. v. Super. Ct., 480 U.S. 102, 115 (1987) (emphasizing that a careful and particularized inquiry into the reasonableness of an assertion of jurisdiction is essential to protecting both the foreign state's and the federal government's interests).

138 Id. at 113; see also Aristech Chem. Int'l v. Acrylic Fabricators Ltd., 138 F.3d 624, 628 (6th Cir. 1998) (highlighting that courts should exercise special care when determining if personal jurisdiction over a foreign defendant is reasonable because of the burdens imposed on the defendant); $c f$. Ins. Co. of N. Am. v. Marina Salina Cruz, 649 F.2d 1266, 1272 (9th Cir. 1981) (observing that plaintiffs can avoid heavy burdens through strategic decisions regarding where to file suit while a defendant lacks that ability). 
routinely require Canadian companies to defend here. ${ }^{139}$ Companies like Teck Cominco, which do business close to the border and to the court where the case is pending, are believed to have the lightest burden. ${ }^{140}$ In addition, a Canadian defendant litigating in the U.S. judicial system finds a system "rooted in the same common law traditions" as Canada. ${ }^{141}$ This also renders the exercise of jurisdiction reasonable. Finally, Washington State and the United States have a strong interest in providing a forum in which their residents can seek redress for injuries that Canadian actors cause within the United States. ${ }^{142}$ Any possible conflict with Canadian sovereignty "is not dispositive because, if given controlling weight, it would always prevent suit against a foreign national in a United States court." 143 Indeed, U.S. Courts have previously exercised jurisdiction based on environmentally harmful conduct that originates from outside the United States. ${ }^{144}$

139 Aristech Chem., 138 F.3d at 628-29. In 1974, the Sixth Circuit heard the first U.S. transboundary pollution case, which involved Canadian landowners who sued three U.S. Corporations whose plants across the Detroit River were emitting noxious fumes. Mitchie v. Great Lakes Steel Division, 495 F.2d 213 (6th Cir. 1974), cert. denied, 419 U.S. 997 (1974). Other courts have found personal jurisdiction over Canadian defendants under the Calder effects test. See, e.g., Brainerd, 873 F.2d at 1257; United States v. Islip, 18 F. Supp. 2d 1047 (Ct. Int'l Trade 1998); EFCO Corp. v. Alumna Sys. USA, 983 F. Supp. 816, 823 (S.D. Iowa 1997).

140 See, e.g., Aristech Chem., 138 F.3d at 628-29 (finding burden on Canadian defendant light when a "short plane flight separates Ontario from Kentucky"); Glinka v. Abraham \& Rose Co., 199 B.R. 484, 497 (D. Vt. 1996) (observing that the burden of traveling from Montreal to Vermont is "slight"); Ensign-Bickford Co. v. ICI Explosives USA Inc., $817 \mathrm{~F}$. Supp. 1018, 1031 (D. Conn. 1993) (emphasizing the "relatively short distance from the defendant's principal place of business in Ontario, Canada, to the site of this litigation in Connecticut."). But see OMI Holdings, Inc. v. Royal Ins. Co. of Can., 149 F.3d 1086, 1096 (10th Cir. 1998) (finding it unreasonable to exercise specific personal jurisdiction over a Canadian company because "[d]efendants will not only have to travel outside their home country, they will also be forced to litigate the dispute in a foreign forum unfamiliar with the Canadian law governing the dispute").

141 Aristech Chem., 138 F.3d at 628-29 (6th Cir. 1998) (quoting Theunissen v. Matthews, 935 F.2d 1454, 1462 (6th Cir. 1991)); see also Ensign-Bickford Co., 817 F. Supp. at 1031 ("[T]he unfairness of forcing a foreign party to litigate in an unfamiliar legal system is alleviated here by the fact that the Canadian legal system is similar in many respects to the legal system in the United States.").

142 See Burger King Corp. v. Rudzewicz, 471 U.S. 462, 483 (1985) (declaring that states often have a substantial, legitimate interest in providing effective ways for its residents to resolve claims).

${ }^{143}$ Gates Learjet Corp. v. Jensen, 743 F.2d 1325, 1333 (9th Cir. 1984).

144 Hanson et al., supra note 20, at 163; see, e.g., The Salton Sea Cases, 172 F. 792, 794, 814-16 (9th Cir. 1909) (permitting action for an injunction and damages for harm to California land caused by diversion of Columbia River, where the tort occurred in Mexico, because the "court had jurisdiction ... to protect property within its jurisdiction").

Additionally, Ohio v. Wyandotte Chemicals Corp., is instructive because its factual 
Another reason why a court would likely find the exercise of jurisdiction reasonable is that Canadian law would also support jurisdiction under the circumstances. Although in many respects Canadian jurisdictional law is stricter than U.S. jurisdictional law, ${ }^{145}$ Canadian law is consistent with the Calder $v$. Jones effects test. ${ }^{146}$ Canadian courts permit the assertion of jurisdiction when damages are sustained in the jurisdiction entering the judgment. ${ }^{147}$ In some regards, Canadian jurisdiction is broader than U.S. jurisdiction because Canada has rejected the purposeful availment test. ${ }^{148}$ For example, British Columbia courts have upheld jurisdiction over U.S. automobile manufacturers for products liability claims brought under the Trade Practice Act $^{149}$ based on the defendants' knowledge that they had introduced

underpinnings are analogous to the current Trail smelter dispute. Ohio v. Wyandotte Chems. Corp., 401 U.S. 493 (1971). In Ohio, the U.S. Supreme Court declined to exercise original jurisdiction over a dispute between the State of Ohio and a Canadian corporation that was allegedly responsible for the release of mercury and toxic metals into Canadian streams flowing into Lake Erie. Id. at 494-95. The plaintiff complained that the Canadian companies' dumping contaminated the "lake's waters, vegetation, fish, and wildlife[.]" Id. at 498-99. The Court declined to exercise original jurisdiction because the claim concerned issues of local law and involved complex factual issues that the Court felt ill-equipped to address. Id. The Court noted, however, that Ohio could bring the nuisance action in its own state courts because the defendant's conduct, "albeit beyond Ohio's territorial boundaries[,]" produced harmful effects in Ohio. Id.

145 Gallob, supra note 92, at 97 (comparing U.S. and Canadian jurisdictional rules and remarking that the Canadian jurisdictional test in a transboundary tort case is less liberal than in the U.S. because "the wrong must be actionable both where the harm occurred and in the forum jurisdiction").

146 See, e.g., Moran v. Pyle Nat'l (Can.) Ltd., [1974] D.L.R.3d 239, 250-51 (Can.) (finding jurisdiction when foreseeable harm could be caused in another province and agreeing that it would be appropriate to "regard a tort as having occurred in any country substantially affected by the defendant's activities or its consequences"); Jenner v. Sun Oil Co., [1952] D.L.R. 526 (Ont. High Ct. J.) (finding jurisdiction over American defendant in a defamation case even though defamatory words were not written or uttered in the jurisdiction when "they were so transmitted as to be published within the jurisdiction in such a manner as to be likely to cause the plaintiff to suffer substantially in his reputation in Ontario").

147 J.G. CASTEL \& JANET WALKER, CANADIAN CONFLict of LAws $\$ 11.11(\mathrm{~h})$, at 11-18 to 11-25 (Butterworths 5th ed. 2004) (discussing exercise of jurisdiction based on "a claim for damages sustained in the jurisdiction"); see also Pei v. Bank Bumiputra Malaysia Berhard, [1999] 41 O.R.3d 39 (Ont. Gen. Div.) (finding jurisdiction proper in Ontario where damage of negligent misrepresentation felt); Acronym (Cayman), Inc. v. Ontario Lottery Corp., [1997] 72 A.C.W.S.3d 450, 12 C.P.C.4th 331 (Ont. Gen. Div.) (discussing jurisdiction based on damages in territory).

148 Vaughan Black, The Other Side of Morguard: New Limits on Judicial Jurisdiction, 22 CAN. BuS. L.J. 4, 23-24 (1993) (arguing that in Moran v. Pyle the Canadian Supreme Court rejected "the American purposeful availment test").

149 Trade Practices Act, R.S.B.C. [1996], ch. 457 (1996) (Can.) (allowing actions for deceptive and unconscionable trade practices). 
the alleged defective products into the stream of commerce, with the knowledge that they would be sold to consumers in British Columbia, regardless of whether they had any other connections with the province. ${ }^{150}$

\section{The Extraterritorial Application of U.S. Environmental Laws}

A second traditional hurdle in holding a Canadian company liable for its alleged pollution under domestic law was whether the U.S. Congress ever intended those domestic laws to apply extraterritorially. ${ }^{151}$ The long-held presumption against extraterritorial application of U.S. laws, however, is not likely to bar relief in cases where Canadian companies release pollution into the United States.

Although Congress has authority to extend its laws beyond the territory of the United States, courts have applied a long-standing presumption against the extraterritorial application of U.S. laws. ${ }^{152}$ As Justice Holmes proclaimed almost a century ago, "the general and almost universal rule is that the character of an act as lawful or unlawful must be determined wholly by the law of the country where the act is done."153 The presumption has become a "canon of construction" for determining unexpressed Congressional intent. ${ }^{154}$ Accordingly, it is now an accepted principle of American law that "unless a contrary intent appears, [Congressional legislation] is meant to apply only within the territorial jurisdiction of the United States."155 This presumption has been eroded in other contexts, ${ }^{156}$ but it has generally remained strong when

150 See generally CASTEL \& WALKER, supra note 147, at 11-24 (citing Robson v. Chrysler Canada Ltd., [2002] 2 B.C.L.R.4th 1).

151 "Extraterritoriality" generally "refers to the operation of a United States law outside the borders of the country so as to encompass actions or activities that occur in whole or in part on the territory of another sovereign power or, alternatively, in international waters." Jonathan Turley, "When in Rome": Multinational Misconduct and the Presumption Against Extraterritoriality, 84 Nw. U. L. REV. 598, 598 n.6 (1990).

152 E.E.O.C. v. Arabian Am. Oil Co. (Aramco), 499 U.S. 244, 248 (1991); see also Foley Bros., Inc. v. Filardo, 336 U.S. 281, 288 (1949) (concluding that the presumption against extraterritorial application is a canon of statutory construction); Am. Banana Co. v. United Fruit Co., 213 U.S. 347, 356-59 (1909) (explaining the strong presumption against extraterritorial application as preventing violation of other nations' sovereignty). See generally Siegle, supra note 96, at 397-404 (summarizing key cases addressing extraterritorial application of U.S. laws).

153 Am. Banana, 213 U.S. at 356. See generally William S. Dodge, Understanding the Presumption Against Extraterritoriality, 16 BERKELEY J. INT'L L. 85 (1998) (discussing the origins of the presumption against extraterritoriality).

154 Aramco, 499 U.S. at 248.

155 Id. (quoting Foley Bros., 336 U.S. at 285); see also Sale v. Haitian Ctrs. Council, 509 U.S. $155,173-74,188$ (1993) (stating that "[a]cts of Congress normally do not have extraterritorial application unless such an intent is clearly manifested.").

${ }^{156}$ Mark Gibney \& R. David Emerick, The Extraterritorial Application of United States Law and the Protection of Human Rights: Holding Multinational Corporations to Domestic 
dealing with environmental questions. ${ }^{157}$ As the Environmental Law Institute has noted, "the presumption against extraterritoriality has been applied with greater force to environmental laws." 158 This is not to say that all environmental laws are interpreted to only apply domestically, ${ }_{159}$ but "current legal doctrine provides little direct support for extraterritorial environmental enforcement." 160

For most legislation, the presumption against extraterritoriality makes perfect sense. Because "Congress generally legislates with domestic concerns in mind," courts may infer from congressional silence that the legislature meant to regulate only activities within the nation's borders. ${ }^{161}$ Moreover, the

and International Standards, 10 TEMP. INT'L \& COMP. L.J. 123, 125, 127-33 (1996) (discussing "glaring inconsistencies in the extraterritorial application of U.S. law"); see also William Dubois, Note, New Drug Research. The Extraterritorial Application of FDA Regulations, and the Need for International Cooperation, 36 VAND. J. TRANSNAT'L L. 161, 172 (2003) (discussing the inconsistency of application of extraterritoriality principles); James E. Ward, Comment, "Is That Your Final Answer?" The Patchwork Jurisprudence Surrounding the Presumption Against Extraterritoriality, 70 U. CIN. L. REV. 715, 715-39 (2002) (discussing the "inconsistency and division among the judiciary" as to how to apply the presumption against extraterritoriality).

${ }^{157}$ See Turley, supra note 151 , at 652 . Commentators have speculated as to the reasons for why courts have accepted extraterritorial application of antitrust and securities law, but have generally not accepted extraterritorial application of environmental law. Some hypothesize that the distinction depends on the existence of market versus non-market effects. See id. at 652-55.

158 ENVIRONMENTAL LAw InSTITUTE, supra note 118, at 37-40 (citing Turley, supra note 151, at 655). Other commentators agree. See, e.g., Richard Heisler, $A$ Whale of a Tale: NRDC v. U.S. Navy and the Attempt to Exempt the Exclusive Economic Zone from the National Environmental Policy Act, 10 Sw. J. L. \& TRADE AM. 125, 137-40 (2004) (discussing how NEPA has not been interpreted to apply extraterritorially); Silvia M. Riechel, Governmental Hypocrisy and the Extraterritorial Application of NEPA, 26 CASE W. RES. J. INT'L L. 115, 126-31 (1994) (discussing extraterritorial application of NEPA).

${ }^{159}$ Courts have been mixed in deciding whether environmental laws can reach beyond the U.S. territorial borders. Compare U.S. v. Mitchell, 553 F.2d 996, 997, 1002 (5th Cir. 1977) (refusing to apply the Marine Mammal Protection Act to a U.S. citizen who captured dolphins while in the coastal waters of the Bahamas because of concerns about impinging on a foreign state's sovereignty), and Amlon Metals, Inc. v. FMC Corp., 775 F. Supp. 668, 674-76 (S.D.N.Y. 1991) (finding that the Resource Conservation and Recovery Act (RCRA) did not permit extraterritorial application of its citizen suit provision), with Michie v. Great Lakes Steel Div., 495 F.2d 213, 216 n.2 (6th Cir. 1974) (implying that a citizen suit for injunctive relief could be pursued under the Clean Air Act for damages to Canadian property caused by U.S. facility emissions).

160 ENVIRONMENTAL LAW INSTITUTE, supra note 118, at 34; see also Mark R. Ruppert, Criminal Jurisdiction Over Environmental Offenses Committed Overseas: How to Maximize and When to Say "No", 40 A.F. L. REV. 1, 14 (1996) (arguing that the "available commentary on the issue of extraterritorial application of U.S. environmental statutes unanimously concludes that these laws do not apply out U.S. territory").

${ }^{161}$ Smith v. United States, 507 U.S. 197, 204 n.5 (1993); Foley Bros. Inc. v. Filardo, 336 
presumption ensures that courts do not precipitate "unintended clashes between our laws and those of other nations which could result in international discord." 162 In addition, other policy considerations make the presumption a sound one. ${ }^{163}$

But there is a large exception to the general presumption, even when dealing with environmental laws. The traditional unwillingness to allow extraterritorial application of U.S. environmental law is not likely to bar claims where serious effects are felt in the United States. ${ }^{164}$ The "effects doctrine," as it is known, "authorizes application of national laws to conduct that, while it does not take place on national territory, has certain 'effects' within national territory." 165 Stated differently, the presumption against extraterritoriality "is generally not applied where the failure to extend the scope of the statute to a foreign setting will result in adverse effects within the United States."166

U.S. 281,285 (stating that in the absence of contrary intent, congressional legislation "is meant to apply only within the territorial jurisdiction of the United States"); see also Dodge, supra note 153, at 92 (discussing this canon of construction in the context of the Aramco case).

162 E.E.O.C. v. Arabian Am. Oil Co. (Aramco), 499 U.S. 244, 248 (1991); see also United States v. Gatlin, 216 F.3d 207, 215-16 (2d Cir. 2000) (explaining that it would be unreasonable to think the first Congress believed it could exercise jurisdiction over lands in a foreign nation).

163 See Dodge, supra note 153, at 90 (explaining that legal scholars offer six different reasons for the presumption); cf. Curtis A. Bradley, Territorial Intellectual Property Rights in an Age of Globalism, 37 VA. J. INT'L L. 505, 513-16 (1997) (identifying five justifications articulated by the Supreme Court for the presumption against extraterritoriality).

${ }^{164}$ Hartford Fire Ins. Co. v. California, 509 U.S. 764, 795-96 (1993) (holding that U.S. antitrust laws applies "to foreign conduct that was meant to produce and did in fact produce some substantial effect in the United States"); see also Schoenbaum v. Firstbrook, 405 F.2d 200, 208 (2d Cir. 1968), rev'd on other grounds en banc, 405 F.2d 215 (2d Cir. 1968) (holding that the Securities Exchange Act applies to transactions abroad that are alleged to violate the Act when they involve stock listed on the U.S. stock exchange and they adversely affect U.S. investors). But see Subafilms Ltd. v. MGA-Pathe Communications Co., 24 F.3d 1088, 1097 (9th Cir. 1994) (refusing to apply federal copyright laws to alleged overseas infringement because the result would cause international discord).

For an early application of the effects doctrine in the domestic law context, see Young v. Masci, 289 U.S. 253, 258-59 (1933), which discusses New York's jurisdiction to prescribe its law in an out-of-state conduct. Cf. Strassheim v. Daily, 221 U.S. 280, 285 (1911) (finding in criminal context that "[a]cts done outside a jurisdiction, but intended to produce and producing detrimental effects within it, justify a State in punishing the cause of the harm as if he had been present at the effect."); MacPherson v. Buick Motor Co., 111 N.E. 1050 (N.Y. 1916) (holding that a manufacturer could be liable under products liability law of state in which the manufacturer was not present, but where the product caused harm).

165 The International Chamber of COMmerce, The EXtraterritorial Application of NATIONAL LAW 36 (Dieter Lange \& Gary Born eds., 1987).

166 RESTATEMENT (THIRD) OF FOREIGN RELATIONS LAW $\S 402(1)$ (c) (1986) (finding that "a state has jurisdiction to prescribe law with respect to . . conduct outside its territory that 
Until the current Trail Smelter dispute, no court had directly addressed the issue of whether CERCLA applies extraterritorially when a foreign source releases pollution into the United States and causes harm within the United States. ${ }^{167}$ Nonetheless, given the "effects doctrine," good reasons exist to believe that if a court were ever to apply CERCLA extraterritorially it would do so in a context like the Columbia River. This is because the effect of the Trail smelter pollution is felt directly and almost exclusively in the United States. ${ }^{168}$ Given its proximity to the border, Teck Cominco knew that the effect of its pollution would be felt by the downstream residents, and knew that those citizens were American. ${ }^{169}$ In cases where the courts have found the environmental laws extraterritorially inapplicable, the effects have almost

has or is intended to have substantial effects within its territory"); see also Envtl. Def. Fund v. Massey, 986 F.2d 528, 531 (D.C. Cir. 1993) (stating that the presumption against the extraterritoriality of statutes does not apply in at least three categories of cases, one of which is when the failure to apply the statute will result in adverse effects within the U.S.); RESTATEMENT (SECOND) OF FOREIGN RELATIONS LAW $\S 18$ (1965) (finding that a state has jurisdiction to prescribe law to conduct outside its territory if the effect of the conduct within the territory is substantial). See generally Susan B. Krolikowski, A Sovereign in a Sovereignless Land? The Extraterritorial Application of United States Law: EDF $v$. Massey, 19 N.C. J. INT'L L. \& COM. REG. 333, 348 (1994).

167 Arc Ecology v. U.S. Dep't of the Air Force, 294 F. Supp. 2d 1152, 1156 (N.D. Cal. 2003) ("Plaintiffs' contention that CERCLA applies extraterritorially is one of first impression."), appeal pending, No. 04-15031 (9th Cir. 2005); cf. Martha A. Candiello, The Extraterritorial Reach of Environmental Laws, 70 TEMP. L. REV. 1235, 1235 (1997) (explaining that, to the author's knowledge, "no court has ruled on the extraterritorial reach of CERCLA").

168 A helpful comparison can be made to the extraterritorial application of securities law. In that context, despite ambiguous statutory language, courts presume that Congress must have intended to protect the United States market from foreign misconduct. See, e.g., Schoenbaum, 405 F.3d at 206 ("We believe that Congress intended the [Act] to have extraterritorial application in order to protect domestic investors who have purchased foreign securities on American exchanges and to protect the domestic securities markets from the effects of improper foreign transactions in American securities."). See generally Turley, supra note 151, at 615-16. Consequently, when a substantial effect is felt in the United States, courts have interpreted the domestic law to apply. Several such cases have involved Canadian companies. See, e.g., Schoenbaum, 405 F.3d at 206 (applying securities laws to extraterritorial shares in wholly Canadian company to Canadian shareholders); Bersch v. Drexel Firestone, Inc., 519 F.2d 974 (2d Cir. 1975) (applying the Securities Act to a Canadian corporation with few connections to the United States when securities violations have a "direct effect" on United States residents). The same extraterritorial application applies in the antitrust context, although the statutory law there also does not specifically provide for extraterritorial application. See generally Turley, supra note 151, at 611-12 (arguing that "courts have ... embraced the far-reaching 'effects doctrine' that permit[s] liability under American antitrust laws whenever an actual or presumed anticompetitive effect on American markets could be shown.").

169 See supra Part I.A.1. 
uniformly been felt outside U.S. territory. ${ }^{170}$ One might even question the assertion that CERLCA would be applied extraterritorially, in the truest of senses, when it addresses a release into the United States. Further, the use of CERCLA in the current Trail Smelter dispute does not seek to regulate foreign conduct with an injunction. Instead, the Colville Tribes are seeking recovery only for the costs of cleaning up the pollution within the boundaries of the United States.

The language of CERCLA, although far from clear, also supports application of its laws to releases into rivers that flow into the United States. CERCLA defines "release" very broadly to mean "any spilling, leaking, pumping, pouring, emitting, emptying, discharging, injecting, escaping, leaching, dumping, or disposing into the environment." 171 The term "environment" is also very broadly defined to include "any ... water, ground water, drinking water supply, land surface or subsurface strata, or ambient air within the United States or under the jurisdiction of the United States." 172 The statute does not mention any territorial limitation. In fact, the reference to "under the jurisdiction of the United States" in CERCLA's definition of environment suggests that Congress intended CERCLA to apply to areas outside United States territorial limits. ${ }^{173}$ In any case, because the Trail smelter discharged pollutants into the Columbia River, which is "water... within the United States," arguably CERCLA would apply.

In Arc Ecology v. U.S. Dep't of the Air Force, ${ }^{174}$ the District Court for the Northern District of California was the first court to address the extraterritorial application of CERCLA. ${ }^{175}$ In that case, the issue was whether CERCLA applied to claims brought by Filipino citizens against the United States to alleged pollution on former U.S. military bases located in the Philippines. ${ }^{176}$ The court held that CERCLA may not be applied extraterritorially to cover properties located within another sovereign nation. ${ }^{177}$ The court, however, was careful to distinguish cases "where a hazardous substance, pollutant or

170 See, e.g., United States v. Mitchell, 553 F.2d 996, 1002 (5th Cir. 1977) (refusing to apply Marine Mammal Protection Act of 1972 to U.S. citizen who captured dolphins while in Bahaman coastal waters); Amlon Metals, Inc. v. FMC Corp., 775 F. Supp. 668, 676 (S.D.N.Y. 1991) (refusing to allow RCRA citizen's suit when the hazardous wastes at issue posed only an imminent and substantial endangerment outside the United States).

17142 U.S.C. $\$ 9601(22)(2000)$.

17242 U.S.C. $\$ 9601(8)(2000)$.

173 See generally Brooke Group Ltd. v. Brown \& Williamson Tobacco Corp., 509 U.S. 209, 229 (1993) ("Canons of construction ordinarily suggest that terms connected by a disjunctive be given separate meanings, unless the context dictates otherwise.").

174294 F. Supp. 2d 1152, 1156 (N.D. Cal. 2003), appeal pending, No. 04-15031 (9th Cir. July 30, 2004).

175 See id. (asserting that the question of whether CERCLA can be applied extraterritorially is one of first impression).

${ }^{176}$ Id. at $1153-54$.

${ }^{177} \mathrm{Id}$. at 1158 . 
contaminant is released or threatened to be released into the U.S. from a bordering country, such as Mexico or Canada."178 In dicta, the court indicated that extraterritorial application of CERCLA would be appropriate in those cases, and referred specifically to the Trail smelter dispute as an example. ${ }^{179}$

This conclusion - that CERCLA applies extraterritorially when the pollution is released into United States territory - is one supported by many commentators. The EPA, ${ }^{180}$ environmental groups, ${ }^{181}$ and the U.S. Department of Justice ${ }^{182}$ conclude that Canadian corporations can be sued to recover cleanup costs for pollution released into the United States from Canada. Legal commentators reach the same conclusion. ${ }^{183}$ Some commentators go even further and argue, contrary to the Arc Ecology decision, that foreign parties may seek relief under CERCLA for activity outside United States territory. ${ }^{184}$ Moreover, recent U.S. Supreme Court decisions are consistent with the distinction drawn in Arc Ecology when the effects are felt in the United States. ${ }^{185}$ Consequently, so long as the lawsuit seeks to recover the costs of

178 Id.

$179 \mathrm{Id}$.

${ }^{180}$ Id. (stating the EPA's position that it can respond under CERCLA to "releases or threatened releases into the United States").

181 ENVIRONMENTAL LAW INSTITUTE, supra note 118, at 40-41 (arguing that some environmental statutes "such as the Superfund provisions of CERCLA, appear to establish a strong basis for certain extraterritorial application" and that cases where there are "clear environmental or public health impacts in the U.S., might provide the most likely basis for pursuing extraterritorial application of environmental laws.").

182 Brief for the U.S. Dep't of Justice, Environment and Natural Resources Division at 18 n.2, 25, Arc Ecology v. United States Dept of the Air Force, 294 F. Supp. 2d 1152 (N.D. Cal. 2003), appeal pending (9th Cir. July 30, 2004) (No. 04-15031) (on file with author).

183 See Peter Obstler, Toward A Working Solution to Global Pollution: Importing CERCLA to Regulate the Export of Hazardous Waste, 16 YALE J. INT'L L. 73, $103-119$ (1991) (arguing that CERCLA should apply extraterritorially); Kim David Chanbonpin, Comment, Holding The United States Accountable For Environmental Damages Caused By The U.S. Military In The Philippines, A Plan For The Future, 4 AsIaN-PaC. LAW \& POL'Y J. $321,370-71$ (2003) (arguing that "the Superfund provisions of CERCLA are equally accessible to extraterritorial application"); Siegle, supra note 96, at 419-21 (discussing a case in which a federal District Court came close to addressing the extraterritorial applicability of CERCLA); $c$ f. Lauren Levy, Stretching Environmental Statutes to Include Private Causes of Action and Extraterritorial Application: Can It Be Done?, 6 DICK. J. ENVTL. L. \& POL'Y 65, 81-91 (1997) (discussing the extraterritorial application of domestic environmental laws, including CERCLA). But see Gerald George, supra note 118, at 10277-78 (arguing, based on textual analysis, that Congress did not intend CERCLA to apply extraterritorially). Gerald George is an attorney for Teck Cominco.

184 Obstler, supra note 183, at 103-119 (analyzing statutory language and legislative history to argue that CERCLA confers "an independent and unrestricted right on any party to bring a legal action for response costs incurred by a hazardous substance release occurring outside the territory of the United States').

185 See, e.g., F. Hoffman-La Roche Ltd. v. Empagran, 124 S. Ct. 2359, 2365-67 (2004) 
remedying domestic environmental injury, a court is likely to find the extraterritorial application of the law reasonable. ${ }^{186}$

The federal district court for the Eastern District of Washington agrees with these conclusions. Since the writing of this Article, but prior to publication, Teck Cominco filed a motion to dismiss the Colville Tribe's lawsuit on grounds that the court lacked personal jurisdiction and that CERCLA could not be enforced against a "Canadian corporation based on conduct which occurred in Canada."187 In an opinion consistent with the analysis set forth above, U.S. district court judge Alan A. McDonald denied Teck Cominco's motion, finding that the court had both subject matter and personal jurisdiction. ${ }^{188}$ But the battle over jurisdiction is far from over. The court certified the matter for immediate appeal to the Ninth Circuit. ${ }^{189}$ The parties believe the case may well end in the U.S. Supreme Court.

\section{Canadian Judicial Enforcement of U.S. Judgments}

A third traditional obstacle to the EPA instituting domestic proceedings to remedy transboundary pollution was the inability to enforce any judgment obtained. Historically, Canadian law has not required enforcement of U.S. judgments and, in fact, Canadian courts discouraged enforcement. ${ }^{190}$ Even the individual provinces of Canada were not required to recognize or enforce judgments from other Canadian provinces. ${ }^{191}$ That, however, changed in the

(reaffirming the principle that domestic antitrust laws may be applied to foreign conduct insofar as that conduct has caused domestic injury).

${ }^{186} \mathrm{Cf}$. id. at 2366 (explaining that foreign harm alone cannot give rise to a domestic claim, but "our courts have long held that application of our antitrust laws to foreign anticompetitive conduct is nonetheless reasonable, and hence consistent with principles of prescriptive comity, insofar as they reflect a legislative effort to redress domestic antitrust injury that foreign anticompetitive conduct has caused.").

187 Pakootas v. Teck Cominco Metals, Ltd., No. CV-04-256-AAM, 2004 WL 2578982, at *4 (E.D. Wash. Nov. 8, 2004).

${ }^{188} \mathrm{Id}$. at *14 (finding that the court has subject matter jurisdiction under CERCLA and personal jurisdiction, the exercise of which is reasonable).

$189 \mathrm{Id}$.

190 Joost Blom, The Enforcement of Foreign Judgments: Morguard Goes Forth Into the World, 28 CAN. Bus. L.J. 373, 373, 376 (1997); see also Kate M.K. Matthews, Comment, The Recent Trend of Canadian Enforcement of United States Judgments and the Future of the Trend Under the Proposed Private International Law Treaty, 19 J.L. \& CoM. 309, 310 312 (2000) (explaining the old common law rule in Canada that "each country and territory is absolutely sovereign, and should not be compelled to enforce the ruling of another country or territory").

191 Morguard Investments Ltd. v. De Savoye, [1990] 3 S.C.R. 1077, 1091-92 (Can.) (listing cases where judgment of one province could not be enforced in another). See generally Robert Wisner, Case Comment, Uniformity, Diversity and Provincial Extraterritoriality: Hunt v. T\&N plc, 40 MCGILL L.J. 759, 761-62, 765-768 (1995) (discussing laws on provincial extraterritoriality, as well as, recognition and enforcement of 
1990s. ${ }^{192}$ If U.S. groups are able to litigate successfully against Canadian companies in the United States and obtain judgments in their favor, those judgments are now likely enforceable in Canadian courts.

In 1990, the Canadian Supreme Court radically changed the obligation of provinces within Canada to recognize and enforce judgments from other provinces. In Morguard Investments Ltd. v. DeSavoye, the Court examined whether a default judgment obtained in Alberta could be enforced against a defendant in a British Columbian court. ${ }^{193}$ The Court concluded that "the courts in one province should give full faith and credit, to use the language of the United States Constitution, to the judgments given by a court in another province or a territory, so long as that court has properly, or appropriately, exercised jurisdiction in that action." 194 In dicta, the Court suggested that this same rule would apply to foreign judgments. ${ }^{195}$ Three years later, the Canadian Supreme Court reaffirmed the basic teachings of Morguard: Canadian constitutional principles require the courts in each province to give "full faith and credit" to the judgments of sister provinces' courts. ${ }^{196}$

Although initially many legal commentators believed Morguard would not apply to non-Canadian judgments, the Canadian courts surprisingly have not been reluctant to enforce U.S. judgments. ${ }^{197}$ As Joost Blom, a University of

judgments).

192 See Morguard, [1990] 3 S.C.R. at 1077 (stating that, when a court has properly exercised jurisdiction in an action, the courts in one province should "give "full faith and credit"' to the judgments of courts in other provinces); Hunt v. T\&N, plc., [1993] 4 S.C.R. 289, 291 (Can.) (holding that a court in one jurisdiction in Canada may consider the constitutionality of the laws of another jurisdiction); see also Blom, supra note 190, at 373 (stating that "[a]s far as the Canadian law on the enforcement of foreign judgments is concerned, the world, in a literal sense, changed in 1990 with the Supreme Court of Canada's decision in Morguard "); Matthews, supra note 190, at 314 ("Canadian courts [have begun] to interpret Morguard to extend beyond interprovincial recognition and enforcement to the recognition and enforcement of foreign judgments from countries with similar judicial systems, such as the United States."). See generally Symposium, Recognition of Extraprovincial and Foreign Judgments: The Implications of Morguard Investments Ltd. v. DeSavoye, 22 CAN. Bus. L.J. 1 (1993).

${ }^{193}$ Morguard, [1990] 3 S.C.R. at 1083.

194 Id. at 1102.

${ }^{195} \mathrm{Id}$. at 1095 (remarking that modern states cannot isolate themselves, and listing certain circumstances in which one country will give effect to a judgment in another country).

196 Hunt, [1993] 4 S.C.R. at 292 (stating that recognition of judgments from other provinces is inherent in the Canadian federation's structure).

197 See Black, supra note 148, at 30 (suggesting that "Morguard has been most enthusiastically employed by the courts of British Columbia," where it was extended to recognize non-Canadian judgments in at least five cases); Blom, supra note 190, at 379-80 (discussing the enthusiasm with which Canadian courts have enforced U.S. judgments); Edward Mazey, The Enforcement Of Labour Orders Outside The Jurisdiction Of Origin, 59 U. TORONTO FAC. L. Rev. 25, 43-45 (2001) (discussing Canadian enforcement of foreign 
British Columbia law professor who has commented extensively on Morguard, wrote:

The extent to which the Morguard rule apparently rested on constitutional underpinnings initially convinced many people, including me, that lower courts would be slow to apply it to non-Canadian judgments. We were quite wrong. The ink was hardly dry on the Morguard judgment when judges at first instance began enthusiastically to enforce truly foreign default judgments under the new principle. ${ }^{198}$

A significant number of U.S. judgments have now been enforced in Canada. ${ }^{199}$

United States $v$. Ivey ${ }^{200}$ provides perhaps the strongest indication that Canadian courts would enforce any CERLCA judgment the Colville Tribes obtain in the Trail smelter dispute. In that case, the EPA, acting under CERCLA, became involved in a superfund site clean-up of a bankrupt waste disposal company located in Michigan. ${ }^{201}$ The EPA sued three defendants to recover the costs of cleanup: Maziv, an Ontario corporation that was the parent corporation of the defunct Michigan waste disposal company; Ineco, an Ontario corporation that had acquired Maziv's shares in the waste disposal company; and Ivey, the president and CEO of Ineco. ${ }^{202}$ In 1991, the United States obtained summary judgments against Ivey and Ineco, and a default judgment against Maziv. ${ }^{203}$ The United States then brought an enforcement action in Ontario for judgments amounting to approximately US\$4.6 million. ${ }^{204}$

The Ontario Court of Appeal enforced the Michigan CERCLA judgment in favor of the United States. ${ }^{205}$ In so ruling, the court rejected arguments that the judgment should not be enforced because of the nature of CERCLA, or as

judgments); cf. Celia Wasserstein Fassberg, Rule and Reason in the Common Law of Foreign Judgments, 12 CAN. J.L. \& JURIS. 193, 193, 221 (1999) (arguing that foreign judgments are exposed to greater and more scrutinizing review in Canadian courts than "local judgments").

198 Blom, supra note 190 , at $379-80$.

199 Id. at 380 n.36 (listing dozens of Canadian decisions enforcing U.S. judgments); Matthews, supra note 190, at 314-16 (discussing United States $v$. Ivey case and Canadian enforcement of U.S. judgments).

${ }^{200}$ See United States v. Ivey, [1995] 26 O.R.3d 533 (Ont. Gen. Div.); see also United States v. Ivey, 747 F. Supp. 1235 (E.D. Mich. 1990) (holding that the U.S. District Court had jurisdiction over the defendants, a Canadian corporation and its president).

${ }^{201}$ Ivey, 747 F. Supp. at 1236-37.

202 Id.; see also Ivey, [1995] 26 O.R.3d at 536-40 (identifying the defendants and the claims against them).

${ }^{203}$ United States v. Ivey, [1995] 26 O.R.3d at 539-41 (describing the procedural background of the case in the U.S.).

204 Id. at 541.

205 Id. at 554. 
against public policy. ${ }^{206}$ The public policy exception to foreign judgment enforcement "has very seldom been invoked successfully in the courts," and the exception is "construed narrowly." ${ }^{07}$ Indeed, the Canadian court found that no sovereignty concerns existed because "the judgments at issue ... go no further than holding [the Canadian defendants] to account for the cost of remedying the harm their activity caused."208 The court went on to note that the "efforts of the [United States] to recover costs it has incurred to remedy the environmental problems at the [Superfund] site" did not "represent an illegitimate attempt [by the United States] to assert sovereignty beyond its borders." 209 From the EPA's and Colville Tribes' perspective, they are doing nothing more than what Ivey approved.

\section{B. The Practical and Conceptual Drawbacks to Solving Transboundary Pollution Disputes with National Adjudication}

Aside from the question of whether U.S. environmental laws can be applied and enforced against a company operating solely in Canada, is the question of whether they should be so applied. ${ }^{210}$ The real or imagined intrusion on Canadian sovereignty, the appearance of unfairness, and the likely Canadian

206 Id. at 540-42; see also Blom, supra note 190, at 400 ("As far as I know, public policy has never succeeded as a defense to an action for the enforcement of a foreign judgment in Canada."); Fassberg, supra note 197, at 194 n.7 (noting the "general view" that denying enforcement on the basis of public policy should be used "sparingly").

207 CASTEL \& WALKER, supra note $147, \S 8.6$ (discussing various cases where British Columbian courts have enforced U.S. judgments despite potential public policy issues and stating that the "Canadian common law courts have rarely excluded foreign laws or judgments on grounds of public policy").

208 Ivey, [1995] 26 O.R.3d at 549.

209 Id.; $c f$. CASTEL \& WALKER, supra note $147, \S 8.5,8.8,8.9$ (discussing an unreported Canadian decision explaining that Canadian courts have regarded considerations of international comity as warranting cooperation in giving effect to environmental laws).

${ }^{210}$ I have avoided the question of whether such extraterritorial application violates international legal norms. Some scholars argue that extraterritorial application of U.S. laws violates international law, or that it is unconstitutional. See, e.g., Lea Brilmayer \& Charles Nochi, Federal Extraterritoriality and Fifth Amendment Due Process, 105 HARV. L. REV. 1217,1223 (1992) (arguing that the Fifth Amendment limits the extraterritorial application of laws); Andreas F. Lowenfeld, U.S. Law Enforcement Abroad: The Constitution and International Law, 83 AM. J. INT'L L. 880 (1990) (arguing that extraterritorial criminal statues that go beyond international law violate U.S. Constitutional Due Process); Robert L. Muse, A Public International Law Critique of the Extraterritorial Jurisdiction of the HelmsBurton Ac (Cuban Liberty and Democratic Solidarity (Libertad) Act of 1996), 30 GEO. WASH. J. INT'L L. \& ECON. 207, $237-267$ (1996) (arguing that the Libertad Act, which applies U.S. law extraterritorially, violates public international law). Other scholars reach the opposite conclusion. See, e.g., Gary B. Born, A Reappraisal of the Extraterritorial Reach of U.S. Law, 24 LAW \& POL'Y INT'L BUS. 1, 19-28, 100 (1992) (concluding that public international law no longer requires strict adherence to the territoriality principle and arguing that extraterritorial application does not violate international norms of comity). 
response all lead to the conclusion that national adjudication is not a long-term solution to transboundary pollution disputes. The United States should not attempt to conduct foreign policy through the U.S. court system.

\section{The Violation of Canadian Sovereignty and the Problems of Regulation Without Representation}

The EPA's use of the U.S. CERCLA laws to regulate extraterritorially the conduct of Canadian companies operating solely in Canada is an affront to Canadian sovereignty. State sovereignty implies independence "that is the right to exercise, within a portion of the globe and to the exclusion of other States, the functions of a State such as the exercise of jurisdiction and enforcement of laws over persons therein."211 Because each nation possesses exclusive jurisdiction within its territory, in theory, each nation shares an equality ${ }^{212}$ with other nations, despite economic or military distinctions. ${ }^{213}$

211 HUNTER ET AL., supra note 2, at 379. The academic literature on State sovereignty is extensive. For a recent, general discussion of the origins and development of the sovereignty notion, see Jenik Radon, Sovereignty: Political Emotion, Not A Concept, 40 StaN. J. INT'L L. 195 (2004). See also John H. Jackson, Sovereignty-Modern: A New Approach to an Outdated Concept, 97 AM. J. INT'L L. 782 (2003) (arguing that the notion of sovereignty has continuing vitality and importance in international law); Kal Raustiala, Rethinking the Sovereignty Debate in International Economic Law, 6 J. INT'L ECON. L. 841, 844-852 (2003) (discussing different conceptions of sovereignty and its relationship to institutions of global governance); Brad R. Roth, The Enduring Significance of State Sovereignty, 56 FLA. L. REV. 1017 (2004) (discussing the role of sovereignty in international law).

The international community has affirmed national sovereignty over the development of natural resources located within the State time and time again. See, e.g., Rio Declaration on Environment and Development, June 14, 1992, Principle 2, 31 I.L.M. 874, 876 (declaring that states have the sovereign right to develop their own resources) [hereinafter Rio Declaration]; Convention on Biological Diversity, June 5, 1992, Art. 15(1), 1760 U.N.T.S. 79 (affirming State's sovereign right over their biological resources and the authority to regulate through national legislation); Convention for the Protection of the World Cultural and Natural Heritage, Nov. 16, 1972, Art. 6(1), 27 U.S.T. 37, 42, 1037 U.N.T.S. 151 (recognizing respect for the sovereignty of States in which territory the cultural and natural heritage is located); Declaration of the United Nations Conference on the Human Environment, June 16, 1972, prin. 21, 11 I.L.M. 1416, 1420 (declaring that states have "the sovereign right to exploit their own resources pursuant to their own environmental policies) [hereinafter Stockholm Declaration].

212 The doctrine of equality of states can be traced back to theorists including Hobbes, Thomas Hobbes, Leviathan (Richard Tuck ed. 1991), and Bodin, Jean Bodin, Six Books of THE Commonwealth 7-9 (M.J. Tooley trans. 1955). See Ruth DonNer, The REGULATION OF NATIONALITY IN INTERNATIONAL LAW 4 (1994).

213 Ian Brownlie, Principles of Public International Law 287 (6th ed. 2003) (explaining that " $[t]$ he sovereignty and equality of states represent the basic constitutional doctrine of the law of nations" and that there exists a "duty on the part of states to refrain from intervention in the internal or external affairs of other states"); see also Muse, supra 
Accordingly, under international law, each nation has the right to use its natural resources as it sees fit according to its own environmental policies, ${ }^{214}$ so long as the use of those resources does not seriously harm other nations. ${ }^{215}$ The view that a state is inviolate within its own territorial borders, so long as it

note 210, at 241-42 (citing James Crawford, Islands as Sovereign Nations, 38 INT'L \& COMP. L.Q. 277, 284-87 (1989)). The Supreme Court discussed early on the principle of equality in the context of the extraterritorial application of law. See The Antelope, 23 U.S. (10 Wheat.) 66, 122 (1825) (finding that "[n]o principle of general law is more universal acknowledged, than the perfect equality of nations .... It results from this equality, that no one can rightfully impose a rule upon another.").

${ }^{214}$ G.A. Res. 1803, U.N. GAOR, 17th Sess., Supp. No. 17, at 15, U.N. Doc. A/5217 (1962), reprinted in 9 UNITED NATIONS RESOLUTIONS: GENERAL ASSEMBLY 107-08 (Dusan J. Djonovich ed., 1974) (affirming right of peoples and nations to permanent sovereignty over their naturai resources); see also International Covenant on Civil and Political Rights, Dec. 16, 1966, art. 1(2), 999 U.N.T.S. 171 (describing the right of people to control their own natural resources); Lake Lanoux Arbitration (Fr. v. Sp.), 12 R.I.A.A. 281 (1957) (recognizing that a state's legitimate right to use its natural resources, so long as it takes into account the interests of other states). See generally G. ELIAN, THE PRINCIPLE OF SOVEREIGNTY OVER NATURAL RESOURCES 2, 12 (1979) (stating that "[h]owever diverse the forms of internal ownership of natural resources, it is the State that has a determining say in the internal utilization of its resources and riches"); Antony Anghie, "The Heart Of My Home": Colonialism, Environmental Damage, And The Nauru Case, 34 HARV. INT'L L.J. $445,472-77$ (1993) (discussing the development of the "permanent sovereignty over natural resources" doctrine).

215 Rio Declaration, supra note 211. The Rio Declaration states:

States have, in accordance with the Charter of the United Nations and the principles of international law, the sovereign right to exploit their own resources pursuant to their own environmental and developmental policies, and the responsibility to ensure that activities within their jurisdiction or control do not cause damage to the environment or damage to the environment of other states or of areas beyond the limits of national jurisdiction.

Id.; see also Stockholm Declaration, supra note 211 (affirming the sovereign right of states to exploit their own resources "pursuant to their own environmental policies" but also affirming state responsibility to "ensure that their activities within their jurisdiction and control do not cause damage to the environment or other states or to areas beyond the limits of national jurisdiction"); Corfu Channel Case (United Kingdom v. Albania), 1949 I.C.J. Rep. 4 (1949) (holding that it is "every state's obligation not to allow knowingly its territory to be used for acts contrary to the rights of other states"); Lake Lanoux Arbitration (Fr. v. Spain), 12 R.I.A.A. 281 (1957), 53 Am. J. Int'l L. 156 (1959) (holding that a state can lawfully utilize the waters of an international river in its territory for its own needs so long as the state does not cause injury to utilizations in the territory of co-riparian states); Island of Palmas Case (U.S. v. Neth.), 2 R.I.A.A. 829 (Perm. Ct. Arb. 1928) (stating that sovereignty signifies independence and that "[i]ndependence in regard to a portion of the globe is the right to exercise therein, to the exclusion of any other State, the function of a State"); Trail Smelter II, supra note 1, at 1965 (holding that "no State has the right to use or permit the use of its territory in such a manner as to cause injury by fumes in or to the territory of another"). 
does not harm others, is "a cornerstone of international law." 216

Because nations are sovereign, international law, be it customary or treaty based, has rarely proscribed pollution of international watercourses. "There is little contemporary support for the view that polluting uses [such as industrial effluent, agricultural run-off, or domestic sewage discharge] are per se impermissible." 217 Recognizing the right to sovereignty, the modern practice is for states to commonly manage international rivers, with the aim of controlling pollution. ${ }^{218}$ In short, although countries are required to cooperate with one another, ${ }^{219}$ individual countries have the "supreme legitimate authority within a territory."220

Holding companies operating outside the U.S., like Teck Cominco, liable under CERCLA would turn these principles of sovereignty and international law on their head. ${ }^{221}$ This statement is an obvious one, but one the United

216 Gallob, supra note 92 , at 87-89. Until this century, the same rules applied to the jurisdiction of individual states within the United States. Pennoyer v. Neff, 95 U.S. 714, 722 (1877) (explaining the "principle of public law" that "no state can exercise direct jurisdiction and authority over persons and property without its territory"); see also JOSEPH STORY, COMMENTARIES ON THE CONFLICT OF LAWS, FOREIGN AND DOMESTIC 19-22 (Morton J. Horwitz and Stanley N. Katz eds., 1972) (describing each nation as having exclusive sovereign jurisdiction within its territory and no power outside it).

217 Patricia Birnie \& Alan Boyle, International Law \& The Environment 306 (2002).

$218 \mathrm{Id}$. at $306,323-31$ (detailing the evolution of regional co-operation in river management, and the "general international endorsement" of it in principle); see also KISs \& SHELTON, supra note 21 , at $475-76$ (discussing the shared resource management of international watercourses in North America); KUOKKANEN, supra note 2, at 148 (describing the increasing adoption of international regulations and organizations to protect water resources).

219 Lake Lanoux Arbitration, 12 R.I.A.A. 281, 53 AM. J. INT'L L. 156, 163-64; see also Stockholm Declaration, supra note 211 (stating that "International matters concerning the protection and improvement of the environment should be handled in a cooperative spirit by all countries, big or small, on equal footing."); Declaration of Principles of International Law Concerning Friendly Relations and Cooperation Among States in Accordance with the Charter of the United Nations, G.A. Res. 2625, U.N. GAOR, 25th Sess., Supp. No. 18, U.N. Doc. A/8082 (1970), reprinted in 9 I.L.M. 1292 (1972). See generally HUNTER ET AL., supra note 2, at 428-30 (explaining the principles of good neighborliness and the duty to cooperate).

${ }^{220}$ Daniel Philpott, On the Cusp of Sovereignty: Lessons from the Sixteenth Century, in SOVEREIGNTY AT THE CROSSROADS: MORALITY AND INTERNATIONAL POLITICS IN THE POSTCold War Era 37, 39 (Luis E. Lago ed., 1996); see also Hans J. MoRgenthau, Politics Among Nations: The Struggle for Power and Peace 299 (6th ed., 1985) (defining "sovereign" authorities as the supreme law-creating and law-enforcing authorities within a territory).

221 The analysis of whether the extraterritorial application of U.S. laws would violate another country's sovereignty is often overlooked. As Jenik Randon has observed:

U.S. laws and actions have a history of unilaterally intruding on the sovereignty other 
States ignores when it forgoes diplomatic solutions, pursuing relief instead through EPA initiated domestic litigation. Indeed, domestic litigation smacks of environmental imperialism because, if the Colville Tribes are successful, the capacity of British Columbia to set its own environmental priorities and policies will be limited sharply. Applying CERCLA to Teck Cominco would set a precedent that Canadian companies, without Canadian consent, are required to follow U.S. environmental policy. Companies that fail to do so would expose themselves to tremendous liability. ${ }^{222}$ Canadian environmental policy - to the extent that it imposes a different standard or a different method of regulation - would be undermined as Canadian companies would feel compelled to follow U.S. laws.

A different yet related problem is that regulating Canadian companies (who often do business solely in Canada) under U.S. environmental laws is inherently undemocratic. ${ }^{223}$ Government ought to rest upon the consent of the

states exercise over their territory. This intrusion is customarily analyzed as extraterritorial application of U.S. law and protection of U.S. sovereignty without really questioning whether such application should be considered a violation of another state's sovereignty. For instance, the United States took control of Cuba for five years after the Spanish-American War of 1898. In 1901 Secretary of War Elihu Root drafted a set of articles that became known as the Platt Amendment. This amendment gave the U.S. government the right to veto legislative enactments by Cuba's parliament. Despite considerable Cuban resistance, it became a part of the 1902 Cuban Constitution. The United States used the amendment several times to send troops to maintain or place cooperative governments in power and to protect investments.

Radon, supra note 211 , at 202 n.29. This general point has not been lost on Canada. See Letter from Anne Charles, Director, U.S. Transboundary Division, Canadian Department of Foreign Affairs and International Trade to Susan Lysyshyn, U.S. Embassy 2 (July 23, 2001) (on file with the author) (regarding EPA's collection of sediment samples and expressing concern over issues of "reciprocity, sovereignty, and liability" in EPA's investigation of Upper Columbia River site).

222 CERLCA is considered to impose a particularly draconian regulatory liability scheme. One federal court has colorfully described CERCLA liability as "a black hole that indiscriminately devours all who come near it." Long Beach Unified School Dist. v. Dorothy B. Godwin Cal. Living Trust, 32 F.3d 1364, 1366 (9th Cir. 1994) (quoting Jerry L. Anderson, The Hazardous Waste Land, 13 VA. ENVTL. L.J. 1, 6-7 (1993)); see also Daniel D. Barnhizer, Recent Development: Joint and Several Liability and Contribution Under CERCLA Sections 107(a)(4)(B) and 113(f)(1), 18 HARV. ENTL. L. REV. 563, 563 (1994) (stating that CERCLA, "[e]nacted in the twilight of the Carter administration[,] ... is often seen as a confused compromise measure which may impose harsh or even draconian penalties to further its two espoused goals"); Lynda J. Oswald, New Directions in Joint and Several Liability Under CERCLA?, 28 U.C. DAvIS L. REV. 299, 313 (1994) ("CERCLA is an unusual law because its liability provisions are simultaneously draconian and nebulous.").

223 For a discussion of the undemocratic nature of extraterritorial application of domestic laws, see Mark P. Gibney, The Extraterritorial Application of U.S. Laws: The Perversion of Democratic Governance, the Reversal of Institutional Roles, and the Imperative of Establishing Normative Principles, 19 B.C. INT'L \& COMP. L. REV. 297, 312-13 (1996). See 
governed. 224 Canadian companies, like Teck Cominco, which if found liable would bear the costs of U.S. regulation, are nearly powerless to change those environmental regulations: they are ineligible to vote; they are limited in their ability to make monetary contributions to participants in the political system; and they have limited ability to influence legislation. ${ }^{225}$ Because of this lack of accountability, exporting U.S. law "by its very nature, goes deeply against the grain of democratic governance."226 Teck Cominco has summed up Canadian sentiments rather pointedly:

Canada sets its own environmental agenda, sets its own environmental standards, has its own body of laws that applies to both the regulation of operators like Trail and any remedial obligations associated with those operations, and it doesn't need any help from the United States. ${ }^{227}$

Not only is the extraterritorial application of CERCLA inconsistent with general democratic principles and an infringement on Canadian sovereignty, it also raises concerns of bias and fundamental fairness. Canadian companies rightfully wish to resist U.S. courts asserting jurisdiction because of the

also Gibney \& Emerick, supra note 156, at 133 (observing that extraterritorial application of the law creates an anomaly that is undemocratic and "represents a vastly different conception of the law that what we have in the domestic realm"); J. Patrick Kelly, Judicial Activism at the World Trade Organization: Developing Principles of Self-Restraint, 22 Nw. J. INT'L L. \& BUS. 353, 373 (2002) (discussing the undemocratic nature of unilateral sanctions under the WTO); William DuBois, Note, New Drug Research. The Extraterritorial Application of FDA Regulations, and the Need for International Cooperation, 36 VAND. J. TRANSNAT'L L. 161, 199-200 (2003) (arguing that '[t]he extraterritorial application of U.S. laws is anti-democratic" because it violates the principle that government rests with the consent of the governed).

224 The Declaration of INDEPENDENCE para. 2 (U.S. 1776) ("Governments are instituted among Men, deriving their just powers from the consent of the governed, That whenever any Form of Government becomes destructive of these ends, it is the Right of the People to alter or to abolish it, and to institute new Government. ..."); THE FEDERALIST No. 39, at 254 (James Madison) (Jacob E. Cooke ed., 1961) (emphasizing that the Constitution's authority would derive from popular consent "given by the people, not as individuals composing one entire nation, but as composing the distinct and independent States to which they respectively belong."); JOHN LOCKE, Two TREATISES OF GOVERNMENT 362 (Peter Laslett ed., Cambridge Univ. Press 1988) (suggesting that government authority to tax can legitimately derive only from consent of the governed); see also Gibney \& Emerick, supra note 156, at 133, 14l-45 (arguing that U.S. law is applied extraterritorially selectively to benefit corporations, and that U.S. health \& labor law should be applied extraterritorially U.S. corporations operating abroad).

${ }^{225}$ See also DuBois, supra note 223, at 199-200 (stating that it is difficult to impossible for foreign nationals to change U.S. law). See generally Gibney, supra note 156, at 312-13 (discussing the difficulties foreign national have influencing U.S. law).

${ }^{226}$ Gibney, supra note 156, at 311 (arguing that exporting U.S. law is undemocratic because the U.S. government will not be held accountable to those bearing the burden of U.S. law).

${ }^{227}$ See Conference Call, supra note 64 . 
appearance, if not the reality, that those courts will favor U.S. citizens. ${ }^{228}$ To state the obvious, U.S. courts apply U.S. choice of law rules and decide cases with U.S. judges, in a manner that expressly promotes U.S. interests. ${ }^{229}$ Similarly, U.S. discovery rules apply; rules with which other countries, who are often unfamiliar with them, criticize as "free-wheeling, unsupervised "fishing expeditions." "230 The application of CERCLA extraterritorially also is arguably unfair because Canadian companies have no reasonable expectation that they could be subjected to this law. ${ }^{231}$ The perception of bias is thus inescapable: "Canada believes that a judge raised within the cultural construct

${ }^{228}$ See, e.g., Hartwin Bungert, Equal Protection for Foreign and Alien Corporations: Towards Intermediate Scrutiny for a Quasi-Suspect Classification, 59 Mo. L. REV. 569 (1994) (arguing that history of discrimination against foreign corporations in United States, justifies heightened scrutiny of regulation of foreign corporations); Kevin R. Johnson, Why Alienage Jurisdiction? Historical Foundations and Modern Justifications for Federal Jurisdiction Over Disputes Involving Noncitizens, 21 YALE J. INT'L L. 1, 35 (1996) (discussing bias against foreign citizens and observing that "[b]ias against noncitizens unfortunately remains to this day."); Elmer J. Stone \& Kenneth H. Slade, Special Considerations in International Licensing Agreements, TRANSNAT'L LAW. 161, 169 (1988) (stating that U.S. and foreign parties both fear discrimination in each other's respective court systems and prefer arbitration as "a more impartial and neutral way to resolve disputes").

229 This concern existed in the early formation of the United States: no State should be compelled to resort to the tribunals of other States for redress, since parochial factors might often lead to the appearance, if not the reality, of partiality to one's own citizens. Bank of United States v. Deveaux, 9 U.S. (5 Cranch) 61 (1809) (emphasizing the need for federal diversity jurisdiction to avoid actual prejudice to out-of-state litigants, and to eliminate fear of prejudice, whether justified or not); Chisholm v. Georgia, 2 U.S. (2 Dall.) 419, 475-76 (1793) (stating that disputes between citizens of different states should be resolved in a federal court because of "the danger or irritation and criminations arising from apprehensions of suspicions of partiality").

${ }^{230}$ R. Edward Price, Foreign Blocking Statutes and the GATT: State Sovereignty and the Enforcement of U.S. Economic Laws Abroad, 28 GEO. WASH. J. INT'L L. \& ECON. 315, 320 (1995) (citing Gary B. Born \& David Westin, International Civil Litigation, in UNITED STATES COURTS: COMMENTARY AND MATERIALS 349-50 (2d ed. 1992)); see also Richard M. Dunn \& Raquel M. Gonzalez, The Thing About Non-U.S. Discovery for U.S. Litigation: It's Expensive and Complex, 67 DeF. Couns. J. 342, 342, 346-47 (2000) (noting that "[a]s evidenced by some of the discovery blocking statutes in [civil law] nations, there is widespread distaste for American-style pretrial discovery" and discussing blocking statutes to prevent U.S. discovery requests).

231 "People can not obey the law unless they know it; they cannot know the law unless they know which law to leam. If I am to know the law that governs an act or transaction, I must be able to identify, before I act, the one state empowered to govern. It is no answer to say that I can usually comply with more restrictive rule, because that eliminates the political authority of the more permissive state." Douglas Laycock, Equal Citizens of Equal and Territorial States: The Constitutional Foundations of Choice of Law, 92 CoLUM. L. REV. 249, 319 (1992). 
of the United States will necessarily tend to favor U.S. interests . . ."232

This bias is particularly acute in a CERLCA citizen's suit when the suit is brought to recover monies for the United States government. Although it superficially appears that the Colville Tribes' suit involves private actors, for all intents and purposes this is a government action. Under the citizen's suit provisions, the Tribes are acting as attorneys general. ${ }^{233}$ Any monetary recovery will be paid to the United States government. ${ }^{234}$ The Tribes receive no compensation, and are asking for none. ${ }^{235}$ The U.S. Government appears supportive of the Tribes' efforts, perhaps because if the Tribes are unsuccessful they may have a claim against the United States Government for violation of its Trust obligations. ${ }^{236}$ Stated differently, the U.S. Government, unwilling or unable to reach a diplomatic solution, is, through the EPA, attempting to use the courts to impose a regulatory order unilaterally on a foreign company, while a citizen's group bears the cost of enforcing that order with the government's blessing.

\section{The Problem of Reciprocal Risk}

The United States government's use of domestic courts to solve transboundary Canada-U.S. pollution disputes is also problematic for U.S. sovereignty. If the United States can apply its law extraterritorially, and such

${ }^{232}$ Christopher L. Doerksen, The Restatement of Canada's Cuban (American) Problem, 61 SASK. L. REV. 127, 134-35 (1998) (discussing Canada's opposition to U.S. judges' discretion to apply U.S. law to Canada).

${ }^{233}$ See 42 U.S.C. $\S 9607$ (2000) (creating liability for environmental damages and cleanup costs); 42 U.S.C. $\$ 9659$ (2000) (allowing "any person" to bring suit if the President has not already commenced a prosecution). See generally Robert W. Vinal, Citizens' Suits Under the Comprehensive Environmental Response, Compensation, and Liability Act (CERCLA) And The Emergency Planning and Community Right-To-Know Act (EPCRA), 55 AM. JUR. PROOF OF FACTS 3D 155 (2003). For a discussion of the citizen's suit provisions of environmental laws, see Kristi M. Smith, Who's Suing Whom? A Comparison of Government and Citizen Suit Environmental Enforcement Actions Brought Under EPAAdministered Statutes, 1995-2000, 29 ColuM. J. EnVTL. L. 359 (2004). See also Jeanette L. Austin, Comment, The Rise of Citizen-Suit Enforcement in Environmental Law: Reconciling Private and Public Attorneys General, 81 Nw. U. L. REv. 220, 222 (1987) (explaining that one of the goals of citizen suit provisions is to supplement government efforts when public authorities do not have adequate resources for the purposes of enforcement).

23442 U.S.C. $\S 9607$ (2000) (providing the general liability scheme); see also Vinal, supra note 233, at 216 (stating that all civil penalties imposed under CERCLA must be paid to the United States treasury).

${ }^{235}$ News Conference Transcript, supra note 47, at 2-3; Complaint, Pakootas v. Teck Cominco Metals, Ltd., supra note 11, at 7 (praying for civil penalties which would be paid to the Treasury).

236 The federal government owes somewhat strict trust obligations toward Indian tribes. See, e.g., Seminole Nation v. United States, 316 U.S. 286, 296-97 (1935) (stating that the Federal Government bears a "distinctive obligation of trust" towards Indian tribes, and as such its conduct is to be "judged by the most exacting fiduciary standards"). 
application is reasonable and appropriate, then presumably Canada can do the same. This is what Karen Mickelson of the University of British Columbia Law Faculty has described as the "reciprocity of risk."237

The specter of reciprocity is a very real concern because transboundary pollution flows both ways. Geographically, about forty-five percent of the significant transboundary rivers flow from the United States to Canada. ${ }^{238}$ In some cases, the nations are "both upstream and downstream on the very same river."239 For this reason, "[i]n matters of pollution, both [the United States and Canada] are 'sinners' and both are 'sinned against." 240 On the East Coast, pollution and smog from U.S. factories and plant operations into Canada is considered a significant problem. ${ }^{241}$ Some estimate that approximately "half the smog in southern Canadian cities including Toronto, Montreal, and Vancouver comes from the United States."242 Further north, U.S. industrial emissions are allegedly causing irreparable environmental harm to Canadian Inuit and artic wildlife. ${ }^{243}$ Historically, the United States has been concerned

237 Mickelson, supra note 2, at 228-29.

238 David G. Lemarquand, Preconditions to Cooperation in Canada-United States Boundary Waters, 26 NAT. RESOURCES J. 221, 223 (1986) ("About fifty-five percent of the ninety significant transboundary rivers flow from Canada to the United States.").

${ }^{239}$ John E. Carroll, Water Resources Management as an Issue in Environmental Diplomacy, 26 NAT. RESOURCES J. 207, 213 (1986).

${ }^{240} I d$. (describing the great mutual dependence of the U.S. and Canada in environmental matters).

241 See AGs Press Canada Regulators to Reduce Emissions from Ontario Coal Stations, ELECTRIC UTIL. WK., May 5, 2003, at 20, available at 2003 WL 11143899 (quoting David Anderson, Canada's Minister of Environment, as saying that there "is 30-times as much pollution coming in the Ohio Valley from plants there [as there is coming from Ontario to the United States] and [that] New York provides double the pollution of the smog that comes from [Ontario]."); Tony Van Alphen, State going to NAFTA Panel Over Ontario Power Plants 'Clean Air Initiative' Being Announced Today in Buffalo, Toronto STAR, May 1, 2003, at C01, available at 2003 WL 18629088 (quoting Ontario Environment Minister Chris Stockwell, as saying that the U.S. has " 200 coal-fired plants in the northeast spewing coal-fired pollution into Ontario" compared to three Canadian plants).

${ }^{242}$ Dennis Bueckert, Looser Controls on U.S. Coal-Fired Plants Won't Hurt Canada, Says Anderson, CAN. PRESs, Jan. 6, 2003. available at 2003 WL 4162168; see also Stewart Elgie, Federal, State and Provincial Interplay Regarding Cross-Border Environmental Pollution, 27 CAN.-U.S. L.J. 205, 215 (2001) (observing the mutual environmental dependence of the U.S and Canada and stating that "[f]ifty percent of Ontario's air pollution comes from the U.S., about eighty percent of the pollution of the Great Lakes comes from the U.S., and over seventy percent of our endangered species are trans-bounded"); Erik K. Moller, Comment, The United States-Canadian Acid Rain Crisis: Proposal for an International Agreement, 36 UCLA L. REV. 1207, 1212 (1989) (citing studies indicating that approximately $50 \%$ of the acid rain falling in Canada may have originated from the United States).

${ }^{243}$ CENTER FOR INT'L ENVTL. L., Inuit Leader Sheila Watt-Cloutier Announces Intention to File a Human Right Claim Against the U.S. for Its Dangerous Greenhouse Gas 
that Canada might successfully use legal rather than diplomatic means to punish U.S. polluters. ${ }^{244}$

This "glass house" concern, that domestic adjudication of the Trail smelter dispute will lead to Canadian retaliation in Canadian courts, has not been lost on American industry. ${ }^{245}$ The National Mining Association and The Edison Electric Institute - both large organizations representing the nation's mines and private utilities - sent letters in April 2004 to Secretary of State Colin Powell, Attorney General John Ashcroft, and EPA Director Michael Leavitt, among others. ${ }^{246}$ In both letters, the groups urged the EPA not to apply its law extraterritorially. The letters stated that the effects would be "devastating" if the U.S. companies had to defend against allegations that their facilities violated Canadian laws. ${ }^{247}$

\section{Canada's Likely Response}

Despite Canadian courts' apparent willingness to enforce judgments from U.S. courts, the Canadian government is unlikely to permit such a practice to continue. ${ }^{248}$ Canada does not react well to what it perceives as incursions into

Emissions, Dec. 15, 2004, at http:/www.ciel.org/Climate/Lawsuit_Inuit_15Dec04.htm (last accessed Feb. 19, 2005).

244 See, e.g., Michie v. Great Lakes Steel, 495 F.2d 231 (6th Cir. 1974) (denying a motion to dismiss in a case where thirty-seven residents of Ontario, Canada, filed a complaint against three corporations that operate seven plants in the United States immediately across the Detroit River from Canada). Other potential suits exist regarding U.S. cross border environmental harm. See, e.g., Donald Goldberg \& Martin Wagner, Human Rights Litigation to Protect the Peoples of the Arctic, 98 AM. SOC'Y INT'L L. PROC. 227 (2004) (discussing possible human rights petition with the Inter-American Commission on Human Rights for damage allegedly caused to the Arctic as a result of U.S. greenhouse gas emissions); Michael T. Delcomynarctic, Comment, National Wildlife Refuge Oil: Canadian And Gwich 'in Indian Legal Responses to 1002 Area Development, 24 N. Ill. U. L. Rev. 789 (2004) (discussing possible lawsuits over environmental impact of drilling in the Arctic National Wildlife Refuge).

${ }^{245}$ Karen Dorn Steele, Plans Differ for Fixing Pollution from Canada: Industry Groups Fear Retaliatory Pollution Accusations, SPOKESMAN-REV. (Spokane), June 20, 2004 at A8.

${ }^{246}$ Letter from Thomas R. Kuhn, President of Edison Electric Institute, to Colin L. Powell, U.S. Secretary of State, and Thomas L. Sansonetti, Assistant Attorney General for the Environment and Natural Resources Division (June 2, 2004) (on file with author) ("The unilateral EPA action raises the possibility of Canadian retaliation against our member companies and other U.S. industries whose emissions may cross the international border."); Letter from Jack N. Gerard, President and CEO of the National Mining Association, to Colin L. Powell, U.S. Secretary of State, John Ashcroft, U.S. Attorney General, and Michael O. Leavitt, Administrator, U.S. EPA 2 (April 22, 2004) (on file with author) (questioning the wisdom of pursuing a Canadian company under U.S. environmental laws and addressing the possibility that Canada and Mexico may pursue similar actions under their own respective domestic laws against U.S. companies).

247 See Letter from Jack N. Gerard, supra note 246, at 2.

248 The concern that the U.S. will dominate Canada, thereby dictating its laws and 
its sovereignty:

Aside from often being inconsistent with international law, extraterritoriality is an unwanted intrusion into a country's sovereignty, and Canada sometimes suffers nightmares about the firmness and durability of its own sovereignty. It naturally bristles when the ugly head of extraterritoriality appears, especially if it is an American head.... Emotions rise, and pride is engaged. ${ }^{249}$

In the past, when the U.S. has attempted to apply its laws extraterritorially, in a way that Canada believes infringes on its sovereignty, Canada has enacted blocking legislation. 250

In 1985, for instance, Canada enacted its Foreign Extraterritorial Measures Act ("FEMA"). ${ }^{251}$ That Act was in response to American antitrust legislation aimed at preventing monopolies among companies, including companies operating and doing business solely in Canada. ${ }^{252}$ FEMA authorizes Canada's

culture, is deeply felt by Canadians. As one commentator has described it:

The logical progression of events unchecked with absolute open borders, with free trade and complete importation of culture is that Canada will become the fifty-first state. You must understand this essential fact to understand the national debate .... [It] is important to remember, at this point at least, Canadians are not Americans and do not want to be Americans. ... The worst insult you can give a Canadian is to say we are the same as Americans. As much as we respect our great neighbor and as much as I acknowledge it is the greatest nation in the history of the world, we do not want to be there. We want all good things. We want our own uniqueness as well.

David Peterson, How Do Canadian Provinces and U.S. States View the Importance of their Relationship with their Cross-Border Counterparts, 27 CAN.-U.S. L.J. 147, 149-51 (2001).

249 Arthur T. Downey, Extraterritorial Sanctions in the Canada/U.S. Context - A U.S. Perspective, 24 CAN.-U.S. L.J. 215, 215 (1998). Indeed, Canada has always been sensitive to being overtaken by U.S. law and culture. In March of 1969, former Prime Minister Pierre Elliott Trudeau vividly described this complex: "Living next to [the United States] is in some ways like sleeping with an elephant. No matter how friendly and even-tempered is the beast, if I can call it that, one is affected by every twitch and grunt." Jutta Brunnée, The United States and International Environmental Law: Living With An Elephant, 15 EuR. J. INT'L L. 617, 641-43 (2004).

${ }^{250}$ For a good discussion of when Canada has enacted such laws, see John W. Boscariol, An Anatomy of a Cuban Pyjama Crisis: Reconsidering Blocking Legislation in Response to Extraterritorial Trade Measures of the United States, 30 LAW \& POL'Y INT'L BUS. 439, 442 (1999) (addressing the various Canadian legal responses to the U.S. extraterritorial measure attempting to strengthen the trade embargo against Cuba).

251 R.S.C., ch. F-29 (1985) (Can.) (granting Canada's Attorney General broad authority to prevent extraterritorial encroachments on Canadian sovereignty with respect to antitrust proceedings).

252 Andrew C. Dekany, Canada's Foreign Extraterritorial Measures Act: Using Canadian Criminal Sanctions to Block U.S. Anti-Cuban Legislation, 28 CAN. BuS. L.J. 210 , 211 (1997) (stating that FEMA's purpose was "to prohibit Canadian corporations, which were subsidiaries of American corporations, from obeying the orders and directives of their American parents insofar as the antitrust legislations was concerned"). See generally 
Attorney General to prevent Canadian courts from recognizing or enforcing antitrust judgments, when those judgments "ha[ve] adversely affected or [are] likely to adversely affect significant Canadian interests."253 The Canadian Attorney General may also choose to block antitrust judgments that have "infringed or [are] likely to infringe Canadian sovereignty."254 Canadians who disobey an Attorney General's order can face criminal prosecution. 255

A more recent example is the Canadian response to U.S. laws that attempt to prevent, impede, or reduce trade with Cuba. ${ }^{256}$ Canada opposes those laws because they attempt to curtail Canadian trade with Cuba, and in doing so infringe on Canadian sovereignty. ${ }^{257}$ Canada believes that the "appropriate forum for U.S. grievances against Cuba is a bilateral and diplomatic one, with the possibility of arbitration or international adjudication by mutual consent" and not through the U.S. courts. ${ }^{258}$ Accordingly, throughout the $1990 \mathrm{~s}$, the Canadian Attorney General entered orders under FEMA prohibiting compliance in Canada with the United States' extraterritorial measures. ${ }^{259}$ The purpose of the orders was to "block the effect of U.S. trade legislation on Canadian companies trading with Cuba."260 Indeed, when the Cuban Democracy Act of 1992 was first enacted in the United States, then Canadian Attorney General, Kim Campbell, immediately signed an order that not only prohibited compliance with that Act within Canada, but also required that Canadians notify authorities immediately if U.S. officials, parent companies, or others contacted them about Cuban trade. ${ }^{261}$ After the enactment of the Helms-

William C. Graham, The Foreign Extraterritorial Measures Act, 11 CAN. Bus. L.J. 410 (1986) (arguing that the Canadian legislature enacted FEMA largely in response to extraterritorial encroachment by the U.S., but also in response to the previously unresolved question of a foreign state's jurisdictional reach).

${ }^{253}$ Foreign Extraterritorial Measures Act, R.S.C., ch. F-29, § 8(1) (1985) (Can.).

254 Id.

${ }^{255}$ See id. $\S 7(1)$ (authorizing fines up to ten thousand dollars or five years imprisonment).

256 See, e.g., The Cuban Democracy Act of 1992, 22 U.S.C. $\S \S 6001-10$ (2000); The Cuban Liberty and Democratic Solidarity (LIBERTAD) Act of 1996, 22 U.S.C. $\S \S 6021-91$ (2000). The LIBERTAD act is also known as the Helms-Burton Act. See Doerksen, supra note 232 , at 137 .

${ }^{257}$ Doerksen, supra note 232, at 134-36 (arguing that Canada, although potentially willing to restrict trade with Cuba, is not willing to sacrifice its sovereignty and submit to unilaterally conceived U.S. policy towards Cuba).

258 Id. at 142.

259 See Dekany, supra note 252, at 215 (detailing three orders issued by the Canadian Attorney General intended to minimize the effect of U.S. anti-Cuba trade legislation); Doerksen, supra note 232, at 142, 151-152 (observing that although FEMA originally only addressed antitrust laws, it has become Canada's "general blocking legislation").

260 See Dekany, supra note 252, at 215.

${ }^{261}$ Foreign Extraterritorial Measures (United States) Order, 1992, SOR/92-584, 126 C. Gaz. Part II 4049 (Can.); see also Doerksen, supra note 232, at 136 (summarizing Canada's 
Burton Act - another piece of extraterritorial U.S. legislation that "attempts to extend the U.S. Cuban trade embargo to individuals and entities that have no connection to the United States"262 - Canada amended its FEMA legislation to specifically provide that "[a]ny judgment given under the [Helms-Burton Act] shall not be recognized or enforceable in any manner in Canada."263

Little reason exists to believe that Canada would not ultimately respond similarly if the U.S. CERCLA laws are read to apply extraterritorially to Canadian companies doing business solely in Canada. Canada will feel compelled to respond. If it does not, the U.S. has few incentives to ever diplomatically discuss transboundary pollution remediation - it can simply use its domestic laws to achieve a self-interested result.

\section{MISSED OPPORTUNITIES: THE UNDERUSE OF INTERNATIONAL LEGAL MECHANISMS}

The above reveals the significant problems, both practically and conceptually, with the U.S. utilizing domestic environmental laws as the means for solving cross-border pollution. This is not to say that the U.S. should sit idly by and permit serious transboundary pollution to occur. By all accounts, the Colville Tribes' lands require immediate clean-up. But the U.S. should choose a more palatable legal mechanism to obtain Canadian cooperation. The 1909 Boundary Waters Treaty between the United States and Canada specifically provides a remedy for resolving these types of transboundary water pollution disagreements. ${ }^{264}$ Moreover, the Treaty has been used

response to the $\mathrm{CDA}$ ).

262 Boscariol, supra note 250, at 442.

${ }^{263}$ Foreign Extraterritorial Measures Act, R.S.C., ch. F-29 § 7(1) (1985) (Can.). In the late 1990s, several commentators discussed the prudence of Canada's blocking legislation. See, e.g., Boscariol, supra note 250, at 443; John Ellicott, Between a Rock and a Hard Place: How Multinational Companies Address Conflicts Between U.S. Sanctions and Foreign Blocking Measures, 27 STETSON L. REV. 1365, 1382 (1998); R. Edward Price, Foreign Blocking Statutes and the GATT: State Sovereignty and the Enforcement of U.S. Economic Laws Abroad, 28 GEO. WASH. J. INT'L L. \& ECON. 315, 315-18, 328-331 (1995) (arguing that foreign blocking statutes are harmful and "may be an overreaction to the problems of U.S. antitrust enforcement abroad"); Russell C. Trice, Comment, HelmsBurton: Canada and Mexico v. The United States - Blocking Legislation is an Unwise Barrier Between Neighbors, 4 Sw. J.L. \& TRADE AM. 87, 95-98 (1997) (suggesting that Canada and Mexico's blocking legislation to the Helms-Burton Act are unreasonable exercises of prescriptive jurisdiction).

${ }^{264}$ See infra Part III.A. Notably, Canada has long been concerned that Teck Cominco's Trail Smelter operations were violating Canada's obligations under the Boundary Waters Treaty. Letter from B.A. Heskin, Regional Director, Pacific \& Yukon, Environment Canada, to R.H. Ferguson, Director, Waste Management Branch, Canadian Ministry of the Environment (Oct. 8, 1981) (stating that spills at the Trail smelter are of particular concern "because of [Canada's] interest in ensuring that we are in compliance with the second paragraph of Article IV of the Boundary Waters Treaty with the U.S"); cf. Memorandum 
successfully many times, and specifically once before in relation to the Trail smelter. If diplomatic resolution is not possible, the Trail Smelter Arbitration from the 1930 s provides a model upon which to resolve transboundary pollution disputes between the United States and Canada. ${ }^{265}$

\section{A. The 1909 Boundary Waters Treaty}

Although often overlooked, for almost a hundred years the United States and Canada have been parties to a bilateral agreement governing pollution of rivers that cross the international boundary. On January 11, 1909, the United States and Canada entered into the Boundary Waters Treaty. ${ }^{266}$ This treaty was one of the first international water rights treaties not focused directly on navigation. ${ }^{267}$ Instead, the two countries intended it as a mechanism to resolve disputes concerning the use of waters flowing along or across the international boundary. ${ }^{268}$ The stated goal of the Boundary Waters Treaty is broad:

$[\mathrm{T}] \mathrm{o}$ prevent disputes regarding the use of boundary waters and to settle all questions which are now pending between the United States and [Canada] involving the rights, obligations, or interests of either in relation to the other or to the inhabitants of the other, along their common frontier, and to make provision for the adjustment and settlement of all such questions as may hereinafter arise. ${ }^{269}$

The Boundary Waters Treaty sets forth three principles or obligations guiding the two countries with respect to their transboundary waters. First, consistent with sovereignty principles, the Treaty recognizes that each country has exclusive jurisdiction and control over the use and diversion of waters in

from Wilson Riley, U.S. Environmental Protection Agency to Alan Hecht (Aug. 13, 1992) (describing Canada Department of Fisheries and Ocean's Report finding that Trail Smelter "slag contains copper and zinc in quantities which are toxic to certain fish species in [the Columbia River].").

265 Note that this is contrary to what some scholars argue: that international arbitration and international environmental law is "flawed" and ineffective. See, e.g., Gallob, supra note 92, at 88-92 (arguing that international environmental law is flawed because of problems with sovereign state consent); $c f$. Cooper, supra note 20, at 262 (finding that some of the disadvantages of international adjudication are valid while others "fail to withstand closer examination").

266 Boundary Waters Treaty, Jan. 11, 1909, U.S.-U.K., 36 Stat. 2448, T.I.A.S. No. 548, available at 1910 WL 19357.

267 Colleen P. Graffy, Water, Water, Everywhere, Nor Any Drop to Drink: The Urgency of Transnational Solutions to International Riparian Disputes, 10 GEO. INT'L ENVTL. L. REV. 399, 424 (1998) (stating that the Boundary Waters Treaty is one of the earliest "nonnavigational international watercourse treaties").

${ }^{268}$ Id. (explaining that the International Joint Commission, created by the Boundary Waters Treaty, still governs watercourse relations, and maintains jurisdiction over rivers and lakes which cross the U.S.-Canadian border)

269 Boundary Waters Treaty, supra note 266, at 2448. 
its territory. ${ }^{270}$ Second, the Treaty prohibits the interference or diversion of the waters' natural flow. 271 To allow remedies for inequitable use, the countries established reciprocal equal court access in cases involving the waters diversion or obstruction. ${ }^{272}$ Finally, the Treaty imposes an obligation not to pollute the boundary waters. ${ }^{273}$ That obligation, found in Article IV, states that: "[i]t is further agreed that the waters herein defined as boundary waters and waters flowing across the boundary shall not be polluted on either side to the injury of health or property on the other."274 There seems little doubt that the Treaty covers issues the current Trail smelter dispute raises, since both the United States and Canada consider slag a pollutant. ${ }^{275}$

Article IV - the pollution provision - was the result of Canadian insistence. During the negotiation of the Treaty, Canada sought to introduce a more restrictive provision, "forbidding [any] water pollution having transboundary consequences" and establishing an agency with police powers to enforce that provision. ${ }^{276}$ The first draft of the Treaty in fact included this restrictive provision. ${ }^{277}$ But the U.S. Secretary of State objected, noting that the strongest provision the U.S. would agree to would be an anti-pollution clause covering boundary and transboundary waters. ${ }^{278}$ The United States opposed any creation of police powers under the Treaty. ${ }^{279}$ Canada was resolute, however,

270 See id. at 2449 (recognizing that injuries to parties on the other side of the boundary resulting from the sovereign's use of waters in its territory shall be treated as if those injuries occurred on the sovereign's side of the boundary).

271 See id. at 2449-50 (allowing derivation from the terms of the treaty by special agreement).

272 See id. at 2449 (allowing injured parties form the other side of the boundary to pursue the same legal remedies that they could pursue were they to have been injured on the opposite side).

273 See id. at 2450.

274 Id.

275 See, e.g., Rosenberg, supra note 86, at 845 (arguing there should be "little doubt that degradation of water quality and/or the introduction of non-native biota, which results in injury to health or property across the border, would be considered to be 'pollution' for the purposes of the Treaty"); Letter from B.A. Heskin, supra note 264 (expressing concern that the Trail smelter may be violating Canada's obligations under the treaty).

276 Jennifer Woodward, Note, International Pollution Control: The United States and Canada - The International Joint Commission, 9 N.Y.L. SCH. J. INT'L \& CoMP. L. 325, $327-$ 28 (1988) (discussing the negotiation of the 1909 Boundary Waters Treaty and the Canadian position).

277 F.J.E. Jordan, Great Lakes Pollution: A Framework for Action, 5 OTTAWA L. REv. 65, 67 (1971) (observing that the joint agency to be established would be vested with the police powers necessary to administer this provision).

${ }^{278} I d$. (remarking that the Secretary of State insisted that the joint agency would have no jurisdiction over the proposed provision).

${ }^{279} I d$. (recounting that the U.S. Senate considered inclusion of the Secretary of State's proposed language an objectionable creation of police powers under the treaty) 
that the Treaty contain a provision prohibiting pollution. ${ }^{280}$ As a compromise, the countries eventually agreed to prohibit pollution "on either side [of the border] to the injury of health or property on the other."281 Indeed, one of the first cases under the Boundary Waters Treaty raised a pollution issue. ${ }^{282}$ The "provision is very unusual considering the date of the treaty, 1909: fifty years before pollution became a major issue." 283

To accomplish the Treaty's goals, the Treaty created an International Joint Commission (IJC). The IJC is a "bi-national body, comprised of [sic] six commissions, three appointed by the United States and three by Canada." 284 The Commissioners are intended to be nonpolitical and impartial. ${ }^{285}$ The IJC is the principle organization responsible for "managing transboundary water resources" for the U.S. and Canada. ${ }^{286}$ As the IJC describes itself:

The Boundary Waters Treaty of 1909 established the International Joint Commission (IJC) to assist the governments of the United States and Canada in preventing and resolving transboundary disputes, primarily regarding water and environmental issues, by undertaking investigations, providing advice and by licensing certain works in boundary and transboundary waters. ${ }^{287}$

The IJC "has been viewed as successful in meeting [that] mandate."288 Additionally, "[ $t]$ he IJC is highly respected and its recommendations are very influential in both the United States and Canada." 289 In the context of

${ }^{280}$ See id. at 68 (explaining that Canada assured the Senate that the provision would only be enforced in very serious situations).

281 Boundary Waters Treaty, supra note 266, at 2450; see also Woodward, supra note 276 , at 328 (commenting that the IJC's authority to hear pollution cases derives from the Article IV prohibition against polluting boundary waters in conjunction with Article IX).

282 I.J.C., FinAl REPORT ON THE POLLUTION OF BOUNDARY WATERS 5 (1918) (discussing the extent that boundary waters pollution in the Great Lakes basin caused injury to public health, and the means to prevent this pollution). See generally Jordan, supra note 277, at 68 (observing that an early case reffered to the IJC concerned the condition of boundary waters both in the Great Lakes and elsewhere along the border).

283 David K.W. Wilson, Jr., Comment, Cabin Creek and International Law - An Overview, 5 PUB. LAND L. REV. 110,118 (1984).

${ }^{284}$ Rosenberg, supra note 86, at 841 (diagramming the general composition of the IJC).

285 BIRNIE \& BOYLE, supra note 21, at 326 (describing the IJC's "independence of both governments" as an "important and unusual characteristic"); Legault, supra note 22, at 4950 (discussing independence of IJC, the Commissioner's solemn declarations to be faithfully and impartially perform their duties, and the Commissioner's immunity from legal processes in both countries).

286 Gallob, supra note 92, at 112-13.

287 INTERNATIONAL JOINT COMMISSION, supra note 91, at 1.

${ }^{288}$ Id.; see also Sewell \& Utton, supra note 96, at 201 (enumerating examples of the U.S. and Canada cooperating in management of their common waterways).

289 Gregory S. Wetstone \& Armin Rosencranz, Transboundary Air Pollution: The Search for an International Response, 8 HARV. ENVTL. L. REV. 89, 92 (1984); see also Cooper, 
curtailing transboundary pollution the IJC's role is seen as vital. ${ }^{290}$ Arguably, no other multilateral institution in the world compares with the IJC in its ambitious institutional design and unusually strong powers. ${ }^{291}$

The Boundary Waters Treaty provides several methods to address transboundary water pollution disputes between Canada and the United States. First, the IJC can issue nonbinding recommendations. ${ }^{292}$ Article IX of the Treaty permits each government, on its own initiative or collectively, to refer matters to the IJC for it to examine and report on any questions or matters of difference arising between the United States and Canada regarding the boundary waters. ${ }^{293}$ These recommendations are not like arbitral awards. ${ }^{294}$ They are technical recommendations based on the special, scientific expertise

supra note 20, at 234 (discussing the "highly relevant International Joint Commission"); Leonard B. Dworsky \& Albert E. Utton, Assessing North America's Management of its Transboundary Waters, 33 NAT. RESOURCES J. 413, 416 (1993) (noting that "[i]n most evaluations, the Commission comes out with high grades" and describing the IJC as a "model[] of success in many ways."); Graffy, supra note 267, at 424-25 (noting that the IJC is "particularly effective" and that the Boundary Waters Treaty is "often emulated as a model for the international community"); Michael Keene, Note, The Failings of the TriState Water Negotiations: Lessons to be Learned from International Law, 32 GA. J. INT'L \& COMP. L. 473, 491-92 (2004) (describing the IJC as "exceptionally effective" and noting that the Treaty "is considered a landmark in water rights negotiations.").

290 Woodward, supra note 276 , at 338,343 (explaining that "[w]hile the I.J.C. lacks the authority to render decisions on pollution issues, it has placed a vital role in curtailing pollution in the Great Lakes" and that it "has played an important role in the rehabilitation of the Great Lakes."); see also James G. Chandler \& Michael J. Vechsler, The Great LakesSt. Lawrence River Basin from an IJC Perspective, 18 CAN.-U.S. L.J. 261, 281 (1992) (arguing that the "IJC has and continues to offer an efficient mechanism for allocating water... use between the two countries and removing potentially serious issues from the binational agenda" and has the potential of playing a "significant role in providing a special type of advice on issues along the common frontier, especially those involving water and environmental matters."); Carl A. Esterhay, Restoring the Water Quality of the Great Lakes: The Joint Commitment of Canada and the United States, 4 CAN.-U.S. L.J. 208, 213 (1981) (describing the IJC as the "water pollution watchdog" for the United States and Canada).

291 Stephen J. Troope \& Jutta Brunnee, Freshwater Regimes: The Mandate of the International Joint Commission, 15 ARIZ. J. INT'L \& COMP. L. 273, 275 (1998) (examining the influence and effect of the IJC relative to its historical context); see also Legault, supra note 22, at 54 (observing that it is "hard to quarrel with [the IJC's] long record of success" and that the "Commission [is] truly one of a kind as a system for the settlement of disputes"); Wang, supra note 20, at 165 (stating that the IJC "has played an important role in the settlement of disputes relating to boundary waters" and that "[i]n over one hundred cases referred to it from 1912 to date [1981] it has produced unanimous reports in all but four cases").

292 Boundary Waters Treaty, supra note 266, at 2452.

${ }^{293}$ Id. See generally Chandler \& Vechsler, supra note 290, at 265-67 (explaining the reference procedure under Article IX).

294 Boundary Waters Treaty, supra note 266, at 2452. 
of the IJC commissioners. Second, the IJC can conduct binding international arbitrations. Article $\mathrm{X}$ gives power to the IJC, upon reference by joint consent of the two nations to "render a decision or finding" upon "any questions or matters of difference... involving the rights, obligations or interests" of the U.S. or Canada. ${ }^{295}$ The consent of the United States is contingent upon the "advice and consent of the Senate."296 Similar to the Boundary Waters Treaty, Article 16 of the 1961 Columbia River Treaty specifically provides that "[d]ifferences arising under the Treaty which Canada and the United States of America cannot resolve may be referred by either to the International Joint Commission for decision." 297

Using the IJC as a method for dispute resolution has been successful. Indeed, from 1909 through 1972, over thirty-six references were sent to the IJC for nonbinding recommendations. ${ }^{298}$ To date, however, no decision has been referred to the IJC for a binding decision. When arbitration between the countries has occurred, a special convention has been used. ${ }^{299}$ Both countries have made "moderate joint use of arbitration." 300 Indeed, one scholar has catalogued over twenty successful arbitrations between Canada and the United States. ${ }^{301}$ The decisions are usually unanimous, ${ }^{302}$ do not divide along national lines, ${ }^{303}$ and are "very influential in both the United States and Canada." 304

295 Id. at 2453.

296 See id:; see also Chandler \& Vechsler, supra note 290, at 267 (stating that the reference under Article $X$ for binding arbitration requires "advice and consent of the Senate, and in Canada, ... consent of the Governor General in Council").

297 See Columbia River Treaty, Jan. 17, 1961, U.S.-Can., 15 U.S.T. 1555, T.I.A.S. No. 5638.

298 Woodward, supra note 276 , at 329.

299 Legault, supra note 22, at 51 (describing the process by which an arbitral decision is passed down by the IJC); see also Chandler \& Vechsler, supra note 290, at 263 (explaining that the Boundary Waters Treaty assigned the IJC "three essentially very different types of tasks," including arbitration, but that the "Commission has never been asked to undertake" its arbitration role).

300 Cooper, supra note 20, at 266; see, e.g., Canada-United States Settlement of Gut Dam Claims: Report of the Agent of the United States Before the Lake Ontario Claims Tribunal, Sept. 22, 1968, 8 I.L.M. 118.

301 Wang, supra note 20, at 224-28 (summarizing and discussing Canada-United States arbitral decisions); see also Legault, supra note 22, at 52-53 (cataloguing some of the major accomplishments of the IJC and explaining that "[o]ver almost ninety years, the Commission has developed a rich body of practice in addressing transboundary water and environmental issues").

${ }^{302}$ Legault, supra note 22, at 52.

303 Id.

304 Wetstone \& Rosencranz, supra note 289, at 134; see also Richard K. Paisley \& Timothy L. McDaniels, International Water Law, Acceptable Pollution Risk and the Tatshenshini River, 35 NAT. RESOURCES J. 111, 121 n.52 (1995) (noting that the countries have a "good track record" of implementing IJC recommendations); Niva Telerant, Riparian 
The Trail Smelter Arbitration is an example of an arbitration under the Boundary Waters Treaty based on a special convention.

\section{B. The Trail Smelter Arbitration Revisited: A Model for Adjudication}

While the Boundary Waters Treaty provides the legal authority to resolve transboundary water pollution disputes through international arbitration, the Trail Smelter Arbitration is a model upon which to base adjudication. The Trail Smelter Arbitration is by far the "most influential decision on transboundary pollution in international law."305 Writing in 1971, Alfred Rubin went so far as to say that "[e]very discussion of the general international law relating to pollution starts, and must end, with a mention of the Trail Smelter Arbitration." 306 The Trail Smelter Arbitration "has become accepted and, to a certain extent, mythologized - as a landmark case in international law." 307 Given its prominence, and that the current dispute involves the same smelter, it is surprising that more scholars have not highlighted the connections between the two.

The facts and circumstances surrounding the Trail Smelter Arbitration are well known, but worth quickly repeating. The arbitration arose over the Trail smelter's emission of sulfur dioxide fumes, which were then blown by winds down the Columbia River valley into the northern part of Washington State..$^{308}$ The sulfur fumes harmed crops, woodlands and fisheries. ${ }^{309}$ In December 1927, the United States proposed that the dispute be referred to the IJC. ${ }^{310}$ By 1931 , the IJC had issued a series of nonbinding recommendations, ${ }^{311}$ including a recommendation that Canada pay the United States $\$ 350,000$ in

Rights Under International Law: A Study of the Israeli-Jordanian Peace Treaty, 18 LoY. L.A. INT'L \& COMP. L. REV. 175, 196 (1995) (explaining that Canada and the United States follow the IJC's recommendations "most of the time").

${ }^{305}$ Merrill, supra note 2, at 947.

306 Alfred P. Rubin, Pollution by Analogy: The Trail Smelter Arbitration, 50 OR. L. REV. 259, 259 (1971). The significance of the Trail Smelter Arbitration has been noted repeatedly and often. See supra note 2 and accompanying text (affirming the influence and importance of the Trail Smelter arbitration).

307 Mickelson, supra note 2, at 223 n.13 (quoting D. Munton, Dependence and Interdependence in Transboundary Environmental Relations, 36 INT'L J. 139, 140 (1980)).

308 See Trail Smelter I, supra note 1, at 1922; Trail Smelter II, supra note 1, at 1945; see also Rubin, supra note 306, at 259-63 (describing the facts underlying the Trail Smelter decision).

309 Trail Smelter I, supra note 1, at 1924-33 (detailing the specific damage done by the Trail smelter).

310 Id. at 1918 (stating that the "United States Government proposed to the Canadian Government that problems growing out of the operation of the Smelter at Trail should be referred to the International Joint Commission").

311 Trail Smelter II, supra note 1, at 1945-46 (discussing the IJC's recommendations pursuant to Article IX of the Treaty). 
indemnification for damages the smelter caused. ${ }^{312}$ The two nations ultimately agreed to this recommendation, but could not agree whether additional compensation was appropriate. ${ }^{313}$ As in the current dispute, Teck Cominco (then Cominco) claimed that the damage was very limited, while the United States found widespread damage. ${ }^{314}$ To resolve this issue, the two countries entered into a Convention in 1935.315 That Convention established a special arbitration tribunal to determine whether Canada should pay the U.S., among other things, compensation for additional damages, and whether the Trail smelter should refrain from causing damage in the State of Washington in the future. 316 The tribunal was not charged with determining any question of liability, but only with fixing the appropriate remedy. ${ }^{317}$

The Tribunal rendered a preliminary decision in April $1938,{ }^{318}$ and rendered its final decision in October 1941..$^{319}$ The Tribunal concluded that Canada, as the country where the harm originated, had a duty to prevent injuries in the United States caused from the use of Canadian property. ${ }^{320}$ Its holding has become an oft-cited passage and a statement of customary international law:

$[U]$ nder the principles of international law, as well as of the law of the United States, no State has the right to use or permit the use of its territory in such a manner as to cause injury by fumes in or to the territory of another... when the case is of serious consequence and the injury is established by clear and convincing evidence. ${ }^{321}$

The Tribunal also established and enforced an elaborate ongoing regime of

${ }^{312}$ Id. at 1946; see also Mickelson, supra note 2, at 225 (detailing the accounts of the Trail Smelter decision).

313 Trail Smelter II, supra note 1, at 1946-48.

314 See id. at 1940 (articulating the U.S. Government's claim for damages); see also Mickelson, supra note 2, at 227.

315 Trail Smelter I, supra note 1, at 1911-12 (stating that the Trail Smelter Arbitral Tribunal was "constituted under ... the Convention between the United States of America and the Dominion of Canada").

316 Id. at 1911.

317 See id.

${ }^{318} \mathrm{Id}$. at 1912 (stating that the deadline for the final decision had to be extended due to inadequate and unsatisfactory nature of the data then available).

319 Trail Smelter II, supra note 1, at 1938.

${ }^{320} \mathrm{Id}$. at 1965-66 (stating that "the Tribunal holds that the Dominion of Canada is responsible in international law for the conduct of the Trail Smelter").

321 Id. at 1965; see also Mickelson, supra note 2, at 220 ("The applicable principle [from the Trail Smelter Arbitration], referred to as the sic utere tuo standard (from the Latin maxim sic utere tuo ut alienum non laedas: use your own property so as not to harm that of another), has been characterized as a description of 'the other face of the coin of sovereignty' and can be seen as a fundamental building block of a system of international environmental protection."). 
sulfur dioxide fume controls. ${ }^{322}$ That regime, which was accepted by both governments, cost the Trail smelter over $\$ 20$ million. ${ }^{323}$

The similarities between the current dispute and the Trail Smelter arbitration are remarkable, and make it particularly well-suited to use as a model of dispute resolution. First, both the United States and Canada perceive there to be significant economic interests at stake. ${ }^{324}$ For Canada, in the 1930s and 40s, the "smelter constituted the economic backbone of the economy of Trail and the surrounding region, and Cominco was the largest employer in the area, paying taxes in the range of one million dollars per year." 325 The same remains true today. ${ }^{326}$ For the United States, the Columbia River Basin area in 1930s was an agricultural area that the inhabitants of the area depended on for their livelihood. Accordingly, in the 1930s "concern over the smelter's activities triggered an early example of environmental activism, involving the formation of a group called the "Citizen's Protective Association"' who fiercely lobbied the U.S. Government to solve the problem. ${ }^{327}$ The Columbia River Basin remains an important agricultural area and is also now a significant tourist destination. ${ }^{328}$ The Colville Tribes, like the 1930s Citizen's Protective Association, are a strong lobby in Washington State. The United States government is also concerned because if it does not solve the pollution problems in the area, it may well be liable to the Colville Tribes for violation of their Trust obligations. ${ }^{329}$

322 Trail Smelter II, supra note 1, at 1966-81.

${ }^{323}$ Rubin, supra note 306, at 272 (stating that "the tribunal's proposed régime for the Trail Smelter was accepted by both governments and complied with by the Canadian firm at a cost of some $\$ 20,000,000 ")$.

${ }^{324}$ Mickelson, supra note 2, at 227-28 (explaining the "[p]erception of importance of interests at stake on both sides of the border").

325 Id. at 228.

${ }^{326}$ See Crook, supra note 6 (stating that Teck Cominco's Trail Operations is the largest employer in the Trail area).

327 Mickelson, supra note 2, at 228.

328 See supra note 31 and accompanying text.

329 Angela Riley, a Professor and Justice to the Supreme Court of the Citizen Potawatomi Nation, has described the trust obligations well:

The doctrine of the "trust responsibility" has largely framed the history of tumultuous relations between the federal government and Indian Nations. While perhaps the most useful instrument in navigating the complex relationship between Indians and the federal government, the doctrine remains, nevertheless, amorphous. At its essence, it imposes a fiduciary obligation on the federal government in dealing with Indian tribes, and commits the government to promoting the preservation and self-governance of sovereign Indian nations.

Angela A. Riley, Recovering Collectivity: Group Rights to Intellectual Property in Indigenous Communities, 18 CARDozo ARTS \& ENT. L.J. 175, 206 (2000). For a general discussion of the trust doctrine, see Mary Christina Wood, Indian Land and the Promise of Native Sovereignty: The Trust Doctrine Revisited, 1994 UTAH L. REV. 1471, 1495 (1994). See also D’ Bey \& Sanscrainte, supra note 51, at 351-53 (discussing trust obligations of the 
Second, the problem of "reciprocity" exists today just as much as it did in the 1930s, the time of the original Trail Smelter arbitration. In the 1930s, the United States was initially unwilling to pursue claims against Canada "given the heavy industrialization on the U.S. side of the border further east and its accompanying concern that a dangerous precedent could be set." 330 Indeed, the United States is believed not to have insisted on the "absolute cessation" of damage because "[t]he acceptance of the principle of absolute cessation of damage might have shut down the Trail Smelter; but it would also have brought Detroit, Buffalo and Niagara Falls to an untimely end." ${ }^{331}$ As described above, these same concerns of U.S. industry still exist. ${ }^{332}$

Third, like the original Trail Smelter case, the question of liability is not really at issue because "a clearly identified source of damage as well as clearly established harm" exists. ${ }^{333}$ Teck Cominco, with its offer of $\$ 13$ million to conduct studies and remediation, does not appear to be disclaiming some liability, either on its part or Canada's. ${ }^{334}$ Indeed, arguing that the slag and mercury did not originate from Canada would be impossible. The real contention is the amount of damages the Trail smelter caused as compared to damage caused by other sources.

\section{Responding to Critics and the Advantages to International Arbitration for Transboundary Dispute Resolution}

As discussed above, the Boundary Waters Treaty provides a legal framework to solve Canadian-U.S. transboundary water pollution disputes. Its language specifically covers pollution, it created a permanent body that has a respected reputation for effective resolution of disputes, and the Trail Smelter Arbitration represents a strong precedent for how international arbitration, under the Boundary Waters Treaty, can succeed. But the question remains why the United States and Canada have not more seriously explored arbitration as a possible solution.

United States to the Colville Confederated Tribes).

330 Mickelson, supra note 2, at 228; see also Trail Smelter II, supra note 1, at 1938-39 ("[W]hile the United States' interests may now be claimed to be injured by the operations of a Canadian corporation, it is equally possible that at some time in the future Canadian interests might be claimed to be injured by an American corporation. ..."); WEISS ET AL., supra note 4, at 259 (acknowledging the U.S. concern for U.S. factories in Detroit, Buffalo and Niagara Falls).

331 Read, supra note 1, at 224-25.

332 See supra note 246 and accompanying text; see also Steele, supra note 245 , at A8 (discussing concerns of the U.S. National Mining Association and Edison Electric that "unilateral EPA action raises the possibility of Canadian retaliation against [U.S.] member companies and other U.S. industries whose emissions may cross the international border").

333 Mickelson, supra note 2, at 227.

${ }^{334}$ U.S. Has No Authority, supra note 63, at FP07 (describing how Teck Cominco has voluntarily offered to pay for environmental studies and portions of the cleanup, thus suggesting its own liability in the issue). 
One explanation may relate to sovereignty concerns. The traditional reluctance in using international arbitration has often been motivated by a concern over sovereignty loss, ${ }^{335}$ or more specifically that the "United States would be handing over to an outside body the determination of issues meant for either the President or Congress." 336 This concern is particularly prevalent with institutions like the World Court. As one lawyer has described:

Recourse to an international forum [like the World Court] to resolve a hotly contested bilateral controversy is not a step that political leaders, even in law-bound societies such as ours, will take lightly. The national constituencies in democracies like those in the United States and Canada, standing behind any given dispute, are not likely to favor a "roll of the dice" in the hands of outside third parties. ${ }^{337}$

One scholar has recently noted that concern over sovereignty loss may be particularly evident in the international environmental law context. ${ }^{338}$

335 The sometimes irrational and overly passionate concern over sovereignty loss is welldiscussed in a recent article by Jenik Radon. Radon, supra note 211, at 202-04 (arguing that Americans often use sovereignty as a battle cry when they fear the U.S. government is entering into an international agreement not subject to domestic checks and balances, although theoretically, the ratification system provides these measures). Other commentators also discuss the concern of losing sovereignty to international or bilateral institutions. See John H. Jackson, The Great 1994 Sovereignty Debate: United States Acceptance and Implementation of the Uruguay Round Results, 36 COLUM. J. TRANSNAT'L L. 157 (1997); Mark L. Movsesian, Sovereignty, Compliance, and the World Trade Organization: Lessons From the History of Supreme Court Review, 20 MICH. J. INT'L L. 775 (1999); Matthew Schaefer, Sovereignty, Influence, Realpolitik and the World Trade Organization, 25 HASTINGS INT'L \& COMP. L. REV. 341 (2002); Charles Tiefer, Adjusting Sovereignty: Contemporary Congressional-Executive Controversies About International Organizations, 35 TEX. INT'L L.J. 239, 263 (2000). This concern over sovereignty loss cuts across political lines in domestic politics. See, e.g., Jon Kamman \& Daniel Gonzalez, Kucinich Struggles For Recognition; Liberal Dem Has 'Broadest Reach', ARIZ. REPUBLIC, Dec. 23, 2003, at B7, available at 2003 WL 73671513 (quoting Kucinich as saying the World Trade Organization and NAFTA have "stripped us of our sovereignty"); Thomas P. Kilgannon, Commentary: Sovereignty gains ... and Losses, WASH. TIMES (D.C.), July 9, 2004, at A18, available at 2004 WL 64160567 (reporting comments by the President of Freedom Alliance - a conservative foundation proclaimed to be dedicated to preserving U.S. sovereignty - about the International Criminal Court); USWA Condemns WTO Ruling on Byrd Amendment; Urges Bush Admin. to 'Defend the Sovereignty of the American Legal System', U.S. NEWSWIRE, Jan. 16, 2003, available at 2003 WL 3726989 (discussing the WTO's alleged preemption of U.S. sovereignty).

${ }^{336}$ Legault, supra note 22, at 59; see also Wang, supra note 20, at 192-210 (discussing Canadian and U.S. attitudes to international adjudication).

${ }^{337}$ Davis R. Robinson, The Convergence of Law and Diplomacy in United StatesCanada Relations: The Precedent of The Gulf of Maine Case, 26 CAN-U.S. L.J. 37, 40 (2000).

338 Brunnée, supra note 249 , at $641-43$ (discussing congressional objections to ratifying the Convention on Biological Diversity); see also Jed Rubenfeld, Unilateralism and 
This concern over losing control has little force in the Canadian-U.S. context. Unlike the World Court or other international tribunals, the IJC is in "our hands and not in the lap[] of foreigners." 339 Half the IJC's members are American. Moreover, if the two countries entered into a compromis, as they did in the original Trail Smelter Arbitration, the parties could designate mutually agreeable arbitrators. ${ }^{340}$ The traditional concern over the loss of sovereignty therefore should not be felt as strongly. This is particularly true since Canada and the United States have a long history of resolving matters successfully through arbitration. ${ }^{341}$ Moreover, the use of tribunals like the IJC to resolve international disputes may well serve as a means to reclaim sovereignty, rather than erode it. ${ }^{342}$ This is particularly true given the reciprocity problem described above. ${ }^{343}$ Furthermore, by allowing U.S. Courts to resolve transboundary water pollution disputes, the U.S. executive branch essentially turns over foreign policy making to the courts, rather than retaining that control in the elected executive. ${ }^{344}$ Perhaps because of this, some public officials have recently urged that the U.S. and Canada more readily seek the advice of the IJC to "prevent future cross-border environmental disputes over proposed Canadian mining and drilling projects near the U.S. border." 345

Constitutionalism, 79 N.Y.U. L. REV. 1971, 2006-2021 (2004) (providing an interesting argument for how international law is contrary to U.S. democratic traditions and is actually antidemocratic).

339 Robinson, supra note 337, at 41.

340 Rubin, supra note 306, at 260 (describing the Trail Smelter Arbitration and observing that the three arbitrators, established by a compromis, were a Canadian, an American, and a Belgian).

341 See Legault, supra note 22, at 53 (summarizing the accomplishments of the IJC); $c f$. Oran R. Young, North American Resource Regimes: Institutionalized Cooperation in Canadian-American Relations, 15 ARIZ. J. INT'L \& COMP. L. 47 (1998) (discussing efforts by Canada and the U.S. to solve problems involving natural resources and the environment, and that the results have been mixed despite the countries' long history of cooperation).

${ }^{342} \mathrm{Kal}$ Raustiala, Rethinking the Sovereignty Debate in International Economic Law, $6 \mathrm{~J}$. INT'L ECON. L. 841, 856-69 (2003) (discussing the sovereignty enhancing powers of international economic institutions).

343 See supra Part II.B.2.

344 Some commentators believe that litigation by its very nature usurps traditional regulatory authority of governmental agencies, and is an end run around democratic political processes. W. KiP VISCUSI, THE REGULATION-Litigation INTERACTION 20 (AEI-Brookings Joint Center for Regulatory Studies, Working Paper No. 01-13, 2001); Robert B. Reich, Don't Democrats Believe in Democracy, WALL ST. J., Jan. 12, 2000, at A22 (arguing that regulation through litigation lawsuits "are end runs around the democratic process").

${ }^{345}$ EPA Backs Role for Bilateral Panel to Avoid Cross-Border Pollution Disputes, InSIDE WASH. PUBlisherS, Aug. 3, 2004 (on file with author) (observing that "One U.S. official says the push to have the International Joint Commission (IJC) deal with potential concerns before granting a permit for Canadian projects is aimed at heading off possible disputes over cross-border pollution, such as the [current Trail smelter dispute]); see also Memorandum from Citizens for a Clean Columbia to the Honorable Senate members of the 
International adjudication has also been disfavored in the past because many believe the arbitration procedure takes too long to complete. ${ }^{346}$ The problem of delay, however, is often exaggerated. ${ }^{347}$ In any case, that is not a reason for rejecting arbitration, even if the resolution of a United States-Canadian water pollution dispute were to take an extended period of time. First, in the case of the Trail smelter, the pollution is not ongoing. The need for immediate injunctive relief therefore does not exist. Nor will the delay in resolving any dispute with Canada delay cleaning up the pollution. The EPA has already designated the area as a potential Superfund site, and has already committed to taking the steps to study and then remedy the contamination of the Upper Columbia River Basin. Finally, the Trail smelter dumped slag into the Columbia River for over a hundred years. A few additional years to resolve this matter, considering that the pollution has largely stopped and remediation is ongoing, are negligible.

Not only do the traditional concerns over international arbitration - its delay and perceived threat to sovereignty - not apply, several benefits to arbitration exist that commend it as a superior method for transboundary dispute resolution. International arbitration is attractive because the United States may not have many choices in how it obtains relief. If Canada, as this Article suggests it will, enacts legislation to "block" U.S. environmental judgments, and if diplomatic solutions are unavailable, international adjudication or arbitration will be the only available avenue of recourse. In light of this choice - between no recovery and recovery through international arbitration international arbitration becomes particularly attractive. Stated differently, the EPA has committed itself to cleaning up the contamination of the Upper Columbia River Basin. Any recovery from Canada to defray costs associated with that clean-up, whether significant or not, is beneficial to the United States, considering that the U.S. is going to pay for clean-up anyway. If the U.S. fails to convince Canada to help fund the clean-up through diplomacy, then "rolling the dice" with a neutral tribunal is a risk-free proposition.

Other benefits to international arbitration exist as well. The former chairman of the Canadian Section of the International Joint Commission has described three advantages to international, third-party adjudication: "First, inequality of power becomes largely irrelevant. Second, the facts can be decided objectively and impartially. Third, the dispute is removed from the

Agriculture and Environment Committee (Sept. 18, 1997) (on file with author) (urging Congress to request intervention by the IJC regarding transboundary pollution in the Columbia River).

346 Cooper, supra note 20 , at 271 (acknowledging that the procedure of international arbitration is criticized for being very long); Wang, supra note 20, at 183 (describing how for many parties the international arbitral experience is "extremely protracted").

${ }^{347}$ Cooper, supra note 20, at 271 (arguing that "delays [in international arbitration] are not so much the fault of the process as of the parties"). 
political sphere and even unpopular results are normally accepted."348 These benefits particularly apply to the IJC, which "has developed a reputation for impartiality that has earned it respect." ${ }^{49}$ The IJC may also have unique strengths given: (1) its prior success in complex fact finding involving environmental pollution; (2) its ability to consider and implement international, environmental and national policies; and (3) its capability of facilitating consensus among governments on complex and politically charged issues. ${ }^{350}$

In contrast, the benefits of an international arbitral tribunal do not exist when transboundary disputes are resolved through domestic litigation. Domestic courts are ill-suited for resolving transboundary water pollution disputes because those disputes involve, by their very nature, the implementation of foreign policy. ${ }^{351}$ Scholars have long lamented that such an approach "can prove an expensive and wasteful way to make policy." 352 John Yoo's description of the limitations of U.S. courts in deciding international disputes is to the point:

Courts are imperfect tools for gathering information, especially when relevant issues for decision involve broader political, economic and social events and trends.... The Supreme Court has long recognized that adjudicating claims arising from events and policies abroad present

\footnotetext{
348 Legault, supra note 22, at 48.

349 David Lemarquand, The International Joint Commission and Changing CanadaUnited States Boundary Relations, 33 NAT. RESOURCES J. 59, 77 (1993).

${ }^{350} \mathrm{Id}$. at 77-78 (discussing the IJC's strengths in solving international environmental disputes); see also Gulden, supra note 95, at 57 (discussing the past successful resolution of many international disputes between the U.S. and Canada by the IJC); Eric M. Bryn, Through A Biodiversity Looking-Glass: An Analysis of the Devils Lake Basin Water Management Plan, 1 Great PlaINS NAT. RES. J. 65, 77 (1996) ("[T]he strength of the IJC in promoting dispute resolution derives from its independence, impartiality, fact-finding capabilities, mediation abilities, consensus building, and adaptability to a changing political climate.").

351 For a good discussion of the failures of the federal court system to resolve questions implicating foreign policy in legal proceedings, see John Yoo, Federal Courts as Weapons of Foreign Policy: The Case of the Helms-Burton Act, 20 Hastings INT'L \& COMP. L. Rev. $747,769-75$ (1997) (arguing that the implementation of foreign policy through federal courts actually hurts the nation because the judiciary lacks a strong unitary voice, being that there are several federal circuits, and foreign states cannot rely on the decision of one circuit as the policy for the whole nation).

352 Id. at 763 (citing Robert A. Kagan, Adversarial Legalism and American Government, 10 J. Pol. ANALysis \& MGMT. 369, 375-79 (1991)); see also Curtis A. Bradley, The Costs Of International Human Rights Litigation, 2 CHI. J. INT'L L. 457, 467 (2001) (discussing the limitations of domestic courts to resolve international legal disputes); Richard B. Bilder, The Role of States and Cities in Foreign Relations, 83 AM. J. INT'L L. 821, 830 (1989) (discussing the dormant foreign commerce clause and noting the inappropriateness of federal courts deciding foreign affair issues); Jack L. Goldsmith, Federal Courts, Foreign Affairs and Federalism, 83 VA. L. REV. 1617, 1668 (1997) (explaining why courts are poorly equipped to deal with questions involving foreign relations).
} 
unique problems for the federal courts... [T] he judiciary is functionally ill-equipped for the task.... Compared to the Presidency, the federal judicial system is decentralized, slow, and at times irrational . . . .353

An additional problem may arise if Canada enacts blocking legislation because such legislation will have the effect of rendering U.S. court judgments unenforceable. ${ }^{354}$ If the judiciary is in the position of "issuing judgments that none expect to be enforced, it enhances an image of powerlessness on the part of the courts" which "serves to dilute public respect" for the judiciary. ${ }^{355}$

Lastly, resolving cross-border pollution disputes through binding international arbitration - utilizing the IJC structure - has collateral benefits: it can lead to longer-term management of boundary waters. In the original Trail Smelter Arbitration, the tribunal not only decided the question of damages, it also created a permanent regime to prevent further damage from sulfur dioxide. ${ }^{356}$ The Tribunal did so after appointing technical consultants and experts, and conducting several studies. ${ }^{357}$ They ultimately set a maximum permissible hourly emission of sulfur dioxide, and prescribed the height of the smelter's stacks. ${ }^{358}$ The creation of a successful pollution control regime is significant because environmentalists increasingly believe that the best way to solve transboundary water pollution is through shared resource management and cooperation. ${ }^{359}$

\section{CONCLUSION}

The Colville Tribes' lawsuit is unprecedented. It represents the first attempt by Americans to apply U.S. environmental laws extraterritorially to a company operating in Canada. Although that lawsuit may be successful, it creates significant diplomatic problems because it encroaches upon Canadian sovereignty and raises the risk of reciprocity. These and other problems ultimately render the extraterritorial application of U.S. environmental law impractical as a long-term solution to cross-border water pollution disputes. Yet the cross-border pollution of the Columbia River Basin is a significant

353 Yoo, supra note 351 at 764-66, 772.

354 See supra Part II.B.3.

355 Yoo, supra note 351, at 767 (citing ThE Federalist No. 78, at 394 (Alexander Hamilton) (Garry Wills ed., 1982)).

356 See supra text accompanying notes 322-323.

357 KUOKKANEN, supra note 2, at 88 (explaining that the Tribunal in the Trail Smelter Arbitration appointed "two technical consultants" and a "consulting meteorologist").

${ }^{358}$ Id. at 88-89.

359 BIRNIE \& BOYLE, supra note 217, at 323-31 (discussing the benefits of, and the reasons why, regional cooperation and shared management provide "the most comprehensive basis for environmental protection and pollution control"); KISS \& SHELTON, supra note 21 , at 467-93 (discussing the importance of "shared resource management" of international watercourses). For a general discussion of the benefits of cooperation in regulating transboundary pollution, see Stoll, supra note 21 , at 186-87. 
problem; one that the United States government cannot ignore. Indeed, transboundary water pollution generally is a problem that the United States cannot afford to ignore as the international spread of pollution will become more prevalent as trade continues to grow.

For these reasons, a model for legal adjudication is necessary when diplomatic solutions prove unworkable. Domestic litigation is not a viable solution, either practically or conceptually. Instead, the United States should explore utilizing international legal mechanisms. As this article suggests, international arbitration, under the 1909 Boundary Waters Treaty, modeled after the famous Trail Smelter Arbitration, provides such a mechanism. Indeed it is surprising, given the similarities between the original Trail Smelter Arbitration and the current dispute, that such an approach has not yet been embraced. 
BOSTON UNIVERSITY LAW REVIEW 